\title{
History of Mid- and Late Holocene Palaeofloods in the Yangtze Coastal Lowlands, East China: Evaluation of Non-Pollen Palynomorph Evidence, Review and Synthesis
}

\author{
James B. Innes ${ }^{1, *}$ and Yongqiang Zong ${ }^{2}$ \\ 1 Science Labs, Geography Department, Durham University, South Road, Durham DH1 3LE, UK \\ 2 Department of Earth Sciences, The University of Hong Kong, Hong Kong, China; yqzong@hku.hk \\ * Correspondence: j.b.innes@durham.ac.uk
}

Citation: Innes, J.B.; Zong, Y. History of Mid- and Late Holocene

Palaeofloods in the Yangtze Coastal

Lowlands, East China: Evaluation of Non-Pollen Palynomorph Evidence, Review and Synthesis. Quaternary 2021, 4, 21. https://doi.org/

$10.3390 /$ quat 4030021

Academic Editor: Matthew Peros

Received: 13 May 2021

Accepted: 23 June 2021

Published: 9 July 2021

Publisher's Note: MDPI stays neutral with regard to jurisdictional claims in published maps and institutional affiliations.

Copyright: (c) 2021 by the authors. Licensee MDPI, Basel, Switzerland. This article is an open access article distributed under the terms and conditions of the Creative Commons Attribution (CC BY) license (https:// creativecommons.org/licenses/by/ $4.0 /)$.

\begin{abstract}
The surface of the lowland deltaic plain around Taihu (Lake Tai), south of the Yangtze river mouth in eastern China, lies near sea level and until recent drainage and development by human societies was mostly covered by wetlands of various types. It was created by regular overbank flooding, mainly from the Yangtze, and the deposition of mostly mineral sediments over the several millennia since sea level regained its current altitude in the early mid-Holocene and progradation of the Yangtze delta began. Fluvial activity has therefore been the dominant influence on sedimentation in the Taihu lowlands, and in the lower Yangtze valley generally, and has determined the character of the mainly inorganic sediment sequences that have accumulated there, with autochthonous deposition of organic sediments within the local wetland plant communities playing a minor role. The presence of both clastic flood horizons and peat layers within the deposits of the Taihu plain attests to great variability in the magnitude of fluvial input from the Yangtze, with repeated extreme floods occurring at some periods, but with periods when the growth of peat layers shows low water tables, little exogenic sediment input and so little fluvial influence. We have examined the published evidence for these different depositional environments in the lower Yangtze and the Taihu plain during the Holocene, comparing the flood history with the middle and upper reaches of the Yangtze catchment. Discrete phases of high or low flooding influence are recognised, and these correspond with large-scale Holocene climate history. Intensified human land use in recent millennia has complicated this relationship, amplifying the flooding signal. Our palynological research shows that algal microfossil type and abundance is a useful proxy for changing water depth and quality in the aquatic environments of the Holocene Taihu wetlands, and can recognise flooding events that are not registered in the floodplain lithological sequences.
\end{abstract}

Keywords: Yangtze river; Holocene; palaeofloods; non-pollen palynomorphs

\section{Introduction}

It can be no surprise that the coastal lowlands around Lake Tai (Taihu), to the west of Shanghai in eastern China, have been greatly influenced by fluvial action in the midand Late Holocene, as their surface altitude is very low, mostly between 2 and $5 \mathrm{~m}$ above sea level, and they lie between the Yangtze (Changjiang) river to the north, one of the largest rivers in the world, and the major Qiantang river to the south, which empties into Hangzhou Bay (Figure 1). There are also several minor rivers that drain the uplands of Tian-Mu-Shan, that fringe the plain to the west, or run between Taihu and the sea, for example the Tiaoxi, Nanxi and Wusongjiang rivers to the south, west and east of the Taihu lake respectively [1,2]. These, and many lesser streams and creeks, have formed an intricate network of drainage channels across the Taihu lowland [3-5] which also had the potential to contribute fluvial sediments to the plain's depositional facies. The Taihu lowland, and nearby coastal lowlands in the area such as the Ningshao plain south of Hangzhou Bay, is an alluvial floodplain that, since its creation about 7000 years ago and its 
subsequent progradation [6], has always experienced high groundwater tables and surface waterlogging, including many shallow lakes $[7,8]$, and so naturally has supported wetland vegetation of various types [9-11].

These wetlands have been much altered and reduced by agricultural development, eutrophication, drainage and urbanisation over the last two millennia but particularly in recent times $[7,8,12-16]$, and the plain's hydrology is likely to be even more affected in future because of recent major damming of the middle Yangtze $[17,18]$, which will result in greatly reduced water discharge in the river's lower reaches, with reduced fluvial sediment input in the Taihu area [19-22]. Throughout mid- and late Holocene times, however, sedimentation in the low-lying coastal plain to the south of the main Yangtze river channel has been massive, and has produced the prograding Yangtze Delta [23-27]. Sedimentation in the Taihu plain has been naturally governed by three main processes: marine influence through fluctuations in sea level and storm surges, autochthonous depositional regimes within freshwater wetlands, and fluvial input from the Yangtze and the smaller rivers that drained the area. Of these, flooding from the Yangtze has been the most important, certainly since postglacial sea-level readjustment was completed in the late mid-Holocene [28-33].

While moderate annual seasonal Yangtze flooding has been a constant factor, introducing fine-grained minerogenic sediment into the floodplain sequence, major floods have occurred regularly throughout the Holocene, continuing into modern times [34,35], with periods during which very extreme flood events affected the Taihu lowlands as well as many other parts of the Yangtze valley [36,37]. Such extreme flooding events were not confined to the Yangtze, although the huge Yangtze catchment and river water discharge rates would exacerbate them, and have been recorded throughout eastern Asia, as in north China [38-45], Japan [46,47] and Korea [48-50]. As the timings of the major flooding phases in all these places correlate closely, it is clear that a regional external driver of extreme freshwater flooding has been involved, with some periods during the Holocene particularly affected. Periods of extreme flooding often had major repercussions for human culture and settlement [51,52], including migration and wars [53-57]. Occasionally major floods were triggered by other factors such as destabilisation and failure of valley palaeolake debris dams [58,59], causing outburst flooding. In almost all cases, however, the linkage of flood events to climate variability and extreme rainfall seems established [60], and the history of the East Asian Summer Monsoon (EASM) [61-63] is central to this, with human land use, especially deforestation, an exacerbating factor in more recent times [64-68]. In this paper we review the evidence for major river flooding and its impacts in the lower Yangtze, primarily in the lowland plain around the Taihu lake, and present new data regarding the value of microfossil assemblages as subtle indicators of past water level changes, and hence for the recognition of major fluvial discharge events.

\section{The Study Area-Geological and Environmental Settings}

\subsection{The Yangtze Delta and the Taihu Lowlands}

The Yangtze Delta is a sedimentary feature of relatively recent, mid-Holocene origin [69-71] (Figure 1), and owes its creation mainly to fluvial transport and deposition of clastic sediment derived from erosion in the catchment of the lower parts of the river system [23,72]. Beneath the Holocene sediments of the Taihu plain, however, are many metres of clastic sediments of pre-Holocene age [73,74], some of which are also of fluvial origin [75]. During the main glacial, Lateglacial and earliest Holocene periods floodplain wetland deposits were confined to the deeply incised valleys of the Yangtze and Quiantang rivers [76-79]. Sea level rose swiftly in the early Holocene $[30,31,33,80]$ until about 7000 years ago, after which major deceleration of the rate of sea-level rise greatly reduced the Yangtze's rate of flow and it changed to an aggrading fluvial system, thus becoming prone to flooding. 


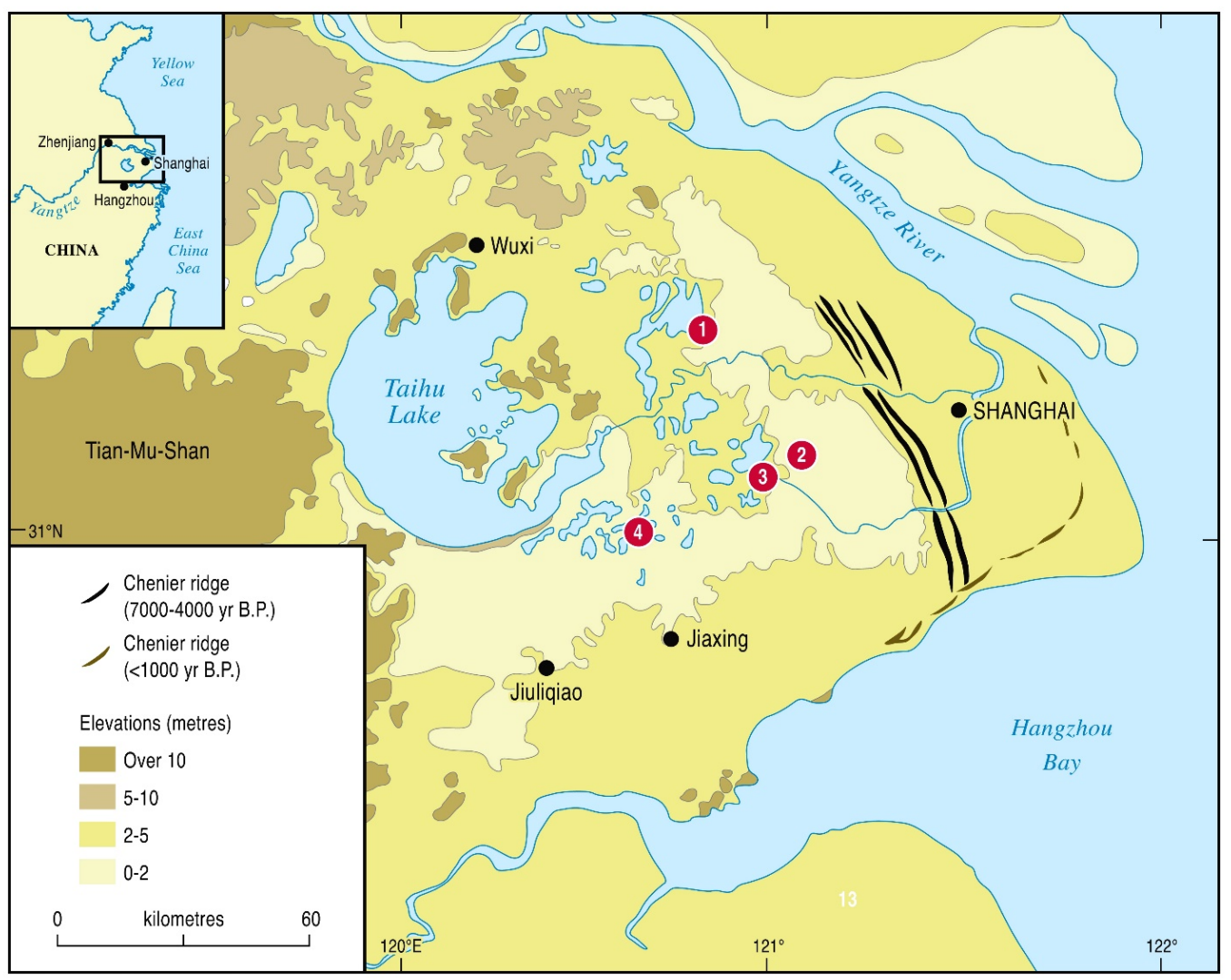

Figure 1. Location of the study area to the east of Taihu Lake in the Yangtze coastal plain, showing the topography, location of smaller lakes and the position of the four study sites 1 . Chuodun 2. Tianyilu 3. Dianshan 4. Pingwang. Adapted from Innes et al. [81] with permission from Elsevier.

The delta began to form [82] as the new high, stable sea level encouraged the fluvial input of water and its entrained sediment from the river into the lowlands to the south of the Yangtze mouth [83-85]. This annual alluvial sediment supply maintained the growth of the delta [86], both eastwards into the sea but also the vertical accretion of sediment within the wetland ecosystems that developed upon it, affecting delta surface morphology $[87,88]$. Delta expansion continued throughout the Holocene until very recently, when reduction in the river's water discharge and in fluvial sediment supply to the delta has followed the construction of many reservoirs in the Yangtze catchment in recent times, causing greatly reduced delta progradation rates $[22,86,89,90]$. Since the construction of the Three Gorges Dam in 2003 sediment deposition has ceased at the subaqueous delta front, which is now eroding [17,91-96].

The freshwater wetlands of the Taihu lowland owed their formation to the culmination of rapid Holocene sea-level rise to near its present level, meaning that from about $7000 \mathrm{cal}$. BP marine sedimentation in the Yangtze delta would occur only during periods of more minor and temporary positive fluctuation in sea level, and would be confined to limited areas around the delta front and to the creeks and inlets which penetrated the deltaic lowlands [5,97], such as a brief but rapid positive pulse in sea level that has been recorded on both sides of Hangzhou Bay between about 4500 and 4400 cal. BP [98-100]. The Taihu lowland has a concave morphology, forming a shallow depression [101] with the centre now occupied by the modern Lake Taihu, and with slightly higher altitude lips to both north and south. This architecture and the creation of chenier barrier ridges to the east [102-104] prevented marine inundation of the bulk of the Taihu lowland during these periodic pulses of higher sea level. Continuous high sea level, however, kept groundwater tables in this very low-lying floodplain area at or above the land surface, initiating and maintaining freshwater wetlands, with semi-aquatic and aquatic vegetation communities [105], except on the occasional small higher areas that rise out of the plain, where woodland developed. 
The natural wetland ecosystems in the Yangtze delta area [15] would have been complex, mainly comprising palustrine marshland dominated by reedswamp with emergent taxa such as Cyperaceae, Phragmites and Zizania depending upon the water depth, then sedge fen with Carex and Typha, and swamp-carr communities with Salix and Alnus as hydroseral succession progressed [106,107] and terrestrialisation ensued as autochthonous sediment accumulated. Limnic clays containing plant roots are typical sediments deposited in these shallow water marsh habitats, and pollen data from several sites suggest that the Poaceae-dominated reedswamps were the most common plant community across the delta plain. In topographically lower areas, however, or when river floods occurred, deeper water existed, with aquatic plants such as Potamogeton, Myriophyllum, Salvinia, Nelumbo and Typha latifolia.

These lower areas formed many lakes during periods of increased rainfall and enhanced fluvial discharge during the mid-Holocene [108-110], and particularly at the time of the later Holocene (c. $4.2 \mathrm{ka} \mathrm{BP}$ ) climatic deterioration [111], when Lake Taihu and many of the Yangtze lakes came into being or expanded $[83,84,109,112-120]$, encouraged by a slow rise in sea level that started at this time [31,109]. Throughout most of the Holocene therefore, the Taihu lowland was primarily a mosaic of aquatic habitats of a range of water depths, but usually shallow marshland, undergoing hydroseral succession through sedimentation but regularly affected by hydrological disturbance through the input of fluvial water and sediment from the Yangtze, a river with regular floods but periodically of the most extreme kind [121]. As alluvial wetlands, those of the Taihu plain would have been flood-adapted and were capable of expanding greatly in size as well as depth because of sudden flooding [122], absorbing floodwaters [123], and converting areas of higher ground to wetland.

\subsection{Recognition of Past Hydrological Changes}

There are various ways to recognise fluvial events in the sedimentary archive, but perhaps the easiest way of gathering information on extreme fluvial conditions and palaeofloods in the lower Yangtze in the past, at least in historical dynastic times, is to accept documentary records of such events and use them to reconstruct flood history [124-131], as has been done elsewhere in China [132]. These are often detailed and there is no reason to consider them any less accurate than modern flood records [133,134]. For example, multiple phases of greatly increased water discharge from the Yangtze into the Chaohu Lake basin at the end of the Han dynasty, for which the flooding might have been at least partly responsible, and in the later Ming and Qing dynasties are noted in contemporary historical annals as extreme flooding events which disrupted settlement and agriculture there [135,136]. Yi et al. [137] noted that their documentary records of floods matched their lithostratigraphic and geochemical evidence for Yangtze floods very well, and correspondence of historical records with such palaeoenvironmental evidence is strong support for its accuracy [138].

Lithostratigraphic analyses can be highly diagnostic of overbank flood events with changes in the grain-size of minerogenic sediments, usually coarsening due to high discharge energy [39,45,119,136-146], and exogenic clastic layers within organic sediment profiles indicating sudden changes in depositional regime [147-149]. Finer-grained, sorted and well-bedded layers often represent fluvial slackwater deposits [38,43,75,140,150-160]. Soil erosion in the river catchments by increased rainfall volume, intensity and runoff was usually the cause [161,162], enhanced in the last few millennia by human land-use activity [21,98], leading to greatly increased delivery of sediment to the lower reaches, the delta and subaqueous delta front sandbars $[163,164]$. Lithofacies and particle-size characteristics of floodplain sediments have been shown to be sensitive to sedimentation changes and flooding in the valleys of other major rivers [165] and have had an important role in recognising flood deposits in the Yangtze valley through their pedostratigraphy $[160,166]$, usually a well-sorted sandy silt, although sometimes of coarser grain size, even gravel. Chemical signatures in clastic layers are also diagnostic of their flood origin $[35,142,148]$, 
while magnetic anomalies in Lake Tai sediments have been interpreted as flood proxy records $[167,168]$. Minerogenic sediment layers in recent floodplain facies correspond closely with high magnitude flood events, as at Tongling and Nanjing in the lower Yangtze area [156], and will have done so in this area in the past [117,160,169], as has been shown in other regional studies of Holocene flood histories (e.g. [41,43,47,148,170]).

Other evidence that has been interpreted as recording flood events is the presence of debris, notably tree trunks and branches that are referred to as 'palaeotrees', that occur within the clastic flood layers. That these are often mixed with coarse-grained sand and gravel sediment [141,145] indicates high-energy flash flooding and transport of material by torrents of flood water, as well as the sudden destruction of local standing trees [52,112,171-174]. The many local water bodies of the Yangtze Delta area, such as Lakes Taihu and Dianshan [141], would also have rapidly expanded $[83,117,120]$. That these layers of clay and silt, often sealing cultural horizons and even major cultural sites, are archaeologically 'sterile' indicates that the scale of the flooding was sufficient to bring local human settlement to an end, and even terminate whole archaeological cultures in the lower Yangtze. Although not every buried tree trunk will have been deposited because of freshwater flooding, the ages of many palaeotrees do correspond to periods of known heavy rainstorms and floods [34,52] and when found in numbers are therefore likely to be a good indicator of past high-magnitude flood events.

Where flooding did not cause major change in lithology, such as within swamps or lacustrine systems where it might have only resulted in increased water levels, deeper water should be discernable through changes in the microfossil assemblages preserved within the limnic or fluvial sediment. Some pollen and spore types, particularly Pinus and Filicales, are buoyant and can be transported long distances with floodwater [175]. A high pollen producer, the sudden abundance of Pinus pollen, particularly in slackwater deposits, may be an indicator of hydrodynamic processes and flooding [176], rather than climatic deterioration as it is often interpreted, although climate instability might have been a driver for the flooding $[175,177,178]$.

Pollen and spores of marsh or aquatic plants might be useful where their water depth preferences are known, and their pollen is unlikely to have been transported significant distances from where the plants grew. Algal spore assemblages, however, could be the most sensitive indicators of changes in water depth [179-182] as they live in situ in the water column, although there is necessarily some overlap in their tolerances [183] so that depth interpretations can not be precise, with direction of depth changes a more reliable interpretation. Also, other variables including trophic status and temperature will have influenced algal abundance. Nevertheless, analysis of freshwater algal spore assemblages can have strong indicator value regarding increases in water depth [184]. They have been used in previous research in China $[178,185]$ including the Yangtze Delta $[186,187]$ and Ningshao Plain $[188,189]$ to reconstruct water depth, for example increased Pediastrum or Botryococcus levels interpreted as indicating a rise in lake levels and/or increased precipitation [181,190-195], and although Pediastrum might represent eutrophication [196], that would itself be a likely result of the input of silt-laden Yangtze flood water. The bluegreen alga Gloeotrichia is sensitive to light levels and prefers clear, open water, but not too deep, as does Volvocaceae [197]. Spores of Zygnema are likely to represent waterlogged marsh environments or very shallow water rather than open water [198-200]. Mougeotia and Spirogyra are common in fluvial sediments and are more likely to represent less deep open water, although their affinities are less well known [185]. Algal assemblages have been an important element in palaeoenvironmental reconstruction in wetland archaeology and palaeolimnology, including floodplain wetlands, in other parts of the world for some time [199-206].

\subsection{Climate and Precipitation Changes}

The dominance of the East Asian Summer Monsoon (EASM) over climate [61,207] in the lower Yangtze area is such that the great majority of water and sediment discharge to the deltaic plain takes place during the summer flood season [208-210], with much of the 
transported fluvial sediment retained within the sedimentary sequences there $[71,177,211]$, and the rest deposited offshore of the delta front [22,66,98,212]. Meteorological conditions suitable for heavy rainfall in the mid- and lower reaches of the Yangtze occur when East Asian atmospheric circulation patterns and pressure systems [213] conspire to reinforce the monsoon, producing persistent and intense rainfall, and annual precipitation variability during the summer monsoon months [214,215], with high amplitude peaks in wet years, causes extreme rainfall events and major flooding [127,216-219]. These frequent and extreme floods are responsible for the acceleration of sedimentation rates [220] in the lower Yangtze lowlands, and the evolution of the floodplain in the Taihu area [156].

Increased fluvial discharge and flooding in the lower Yangtze has therefore been intimately connected with fluctuations in climate and therefore in catchment rainfall [221,222], and these were governed primarily by changes in the strength of the EASM and its interactions with the El Niño-Southern Oscillation (ENSO) events [160,161,216,223-234]. Regional research on this connection [48,49,164,217,235-237] suggests that major hydrological changes in the Yangtze valley are consistent with a stronger ENSO and weaker EASM, so that the monsoon rain belt does not penetrate far north in China and remains static over the Yangtze river, concentrating rainfall there and producing long rainstorms and extreme flood events [160,227]. Blender et al. [162] showed strong correlation between ENSO and Tibetan snow-melt, influencing runoff and hydrology in the Yangtze catchment, and Yangtze floods still correlate with ENSO [212]. Weak EASM and strong ENSO conditions also correlate well with a cold climate in eastern China [238], as shown in the $\delta^{18} \mathrm{O}$ record from Shanbao cave [239] to the west of the Taihu plain, which agrees with the other reconstructions of monsoon history and climatic change for east China [216,228,240-243].

Li et al. [244] have produced a pollen-based reconstruction of rainfall and temperature history for the lower Yangtze region, showing that the early and mid-Holocene had a warm, wet and humid climate with a strong EASM, with a cooling and drying climate after about $5000 \mathrm{cal}$. BP as the EASM gradually weakened. This supports previous climate research in the area [176,233,245-248]. Periods of lower rainfall did occur, as between 7500 and 6500 cal. BP [249], but several high amplitude cold events are the most notable Holocene climatic features [233], occurring particularly around 8200, 5500, 4200 and 2800 cal. BP, the later examples corresponding with the stronger ENSO, and this record of abrupt climatic fluctuations confirms previous findings $[120,234,250]$. These climate deterioration events were global phenomena. The 8200 cal. BP event [251,252] was of considerable significance in China $[228,253,254]$ including the Taihu region $[164,233]$ but the major cold event starting at $4200 \mathrm{cal}$. BP was particularly pronounced [111,164,255-258] and represents the transition to the Late Holocene neoglacial period [259,260], and is now officially recognised as such [261].

As well as being much colder, there was extreme variability in precipitation from this time onwards [221,262,263], with high amplitude fluctuations leading to severe flooding, as is common during periods of climate transition and instability [264]. Such an abrupt climate change must have had a significant impact [265-269] on human settlement and agriculture in eastern China, no matter how resilient their society [270], including the Yangtze delta where the high population of the well-developed Neolithic Liangzhu culture [271-274] depended on benign climate, stable hydrological conditions and water management [275] for its subsistence. Another abrupt phase of climatic deterioration occurred after the 2800 cal. BP event with the lakes that came into being around $4000 \mathrm{cal}$. BP [225] expanding due to increased rainfall [244,276,277], magnified by river floods [151], and lasting to about 1200 cal. BP [278]. This 2800 cal. BP climate deterioration is marked in stalagmite records in China [161,242] and India [217,279], and in global environmental archives [280,281], and is one of the largest drivers of Holocene hydrodynamic instability and flooding.

\subsection{Yangtze Floods}

The Yangtze has always been prone to some moderate seasonal flooding because of increased monsoonal rainfall during the summer months [72,210,282], although to a 
limited degree and varying from year to year. There has therefore been an annual small to moderate input of river floodwater into the Taihu floodplain during the Holocene, but one that usually would not carry a large sediment load [156]. However, the Yangtze valley is a part of China notorious for great floods $[283,284]$ and some extreme examples have occurred in the last two millennia [131], including in recent times [63,168,222]. Zheng et al. [127] have noted that great floods in late dynastic times were common between 900 and 600 cal. BP, and Wu et al. [285] and Luo et al. [286] noted that many major flood events occurred during the Ming and Qing dynasties after 600 cal. BP during an extended cold phase corresponding to the Little Ice Age $[62,75,129,287,288]$.

High-intensity flooding has also occurred regularly in the last two centuries [35,156,289], and floods in the 19th and 20th centuries have been as bad as any in the last 1500 years. As recently as 1889, 1954 and 1998, the greatest magnitude floods have been recorded in both the mid- and lower Yangtze [146,160,168,220,290,291], with flood deposits of the 1998 event widespread [119]. The EASM rain belt has moved southwards in recent decades, bringing heavy rains and floods to the lower Yangtze [221,292,293], such as the extreme rainfall there in 2015 [219]. Usually such recent high magnitude floods have left a lithostratigraphic signature in floodplain and lake sediments $[156,294]$. These more recent examples provide analogues for mid- to late Holocene flood history, as the ancient and modern flood deposits are morphologically very similar [295] and represent similar depositional environments and processes [138].

\section{Materials and Methods}

Sub-samples from the cores were prepared for palynological analysis at five-centimetre intervals, using standard laboratory techniques [296]. Alkali digestion with $\mathrm{NaOH}$ was followed by sieving at $180 \mu \mathrm{m}$, removal of silicate mineral material with hydrofluoric acid, and acetolysis. The residue was stained before mounting on microscope slides. Although designed for pollen and spores, the work of Clarke [297] has shown that these procedures do little to affect the preservation of most other microfossils, such as algae or fungal spores. Microfossils are defined as palynomorphs which passed through the $180 \mu \mathrm{m}$ sieve. Reference keys were used to aid identification of pollen and spores, primarily Wang et al. [298] for pollen and Zhang et al. [299] for pteridophyte spores. At least 200 land pollen grains were counted at each level, often more, as well as all aquatic pollen, pteridophyte and bryophyte spores that were present.

Full pollen data are not presented in this paper because the taphonomy of pollen grains means that they will represent extra-local as well as in situ plant communities, so providing a spatially composite pollen assemblage that derives from several plant communities in the wider area. It therefore might well not record hydrological changes at a particular site itself, and would blur any signal of rapid water depth changes, as caused by flooding events, but would record a mosaic of wetland habitats [176]. It is important to note, however, that several pollen taxa were recorded in every diagram that indicated local wetland environments of deposition, including organic soil, reedswamp and marsh, or more open water. These included Poaceae (grass) pollen grains below $40 \mu \mathrm{m}$, which are likely to originate from wild reedswamp and marsh grasses such as Phragmites and Zizania [298,300], and Cyperaceae, as well as the emergent aquatic Typha angustifolia, an important element of past Taihu wetland vegetation [11,178,301,302]. Obligate aquatic pollen types were also occasionally present in very low frequencies, notably including Myriophyllum and Typha latifolia, indicating areas of deeper water. A combined curve for aquatic pollen, which is comprised mainly of T. angustifolia, is shown on the diagrams, calculated as percentages of total land pollen.

The pollen data from the sites in this paper have been published previously either in full $[81,260]$ or summary form $[85,303]$. In this paper we concentrate on the record of non-pollen palynomorphs (NPPs), mainly comprising algal and fungal spores [304], which are much more likely to reflect in situ hydrological conditions such as water depth. Fungal NPPs would have been produced in situ at the core sampling point and usually are hardly 
transported from their point of production to point of deposition [305], unless redistributed by a force such as a fluvial flooding event which might affect algal spores living in aquatic environments, which are the subject of this paper.

At least 100 algal and fungal spores were counted at each level, and their identification was achieved by reference to the illustrations and descriptions in several published papers [180,306-308] although, as many NPPs have not yet been identified and remain known only by their Type (HdV) number in the Hugo de Vries Laboratory catalogue in Amsterdam, taxonomic identification was not always possible, although the palaeoecology of individual types is well known from previous research [304,308]. HdV numbers are shown on the microfossil diagrams and with the first mention of an NPP type in the text. In this paper microfossil diagrams for each site show only the curves for selected individual NPP taxa that are present in substantial frequencies and are sensitive to water level, calculated as percentages of the total NPP counting sum. The ratio between algal and fungal spores should provide an indication of water table changes, with rises in fully aquatic algal spore frequencies showing increased water depth whereas fungal spore taxa and marsh algae represent more stable semi-terrestrial or shallow marsh conditions. Rapid rises in open water aquatic algal taxa can be interpreted as recording flooding events. Following the literature cited above, Volvocaceae (HdV-128), Spirogyra (HdV-130), Gloeotrichia (HdV146), Mougeotia (HdV-313) and Pediastrum (HdV-760) are considered fully aquatic while Zygnema (HdV-58), HdV-306 and HdV-708 are considered shallow wetland reedswamp or marsh taxa. Mougeotia may signify less eutrophic conditions [309]. Common fungal spores considered as indicating wet semi-terrestrial conditions are Sordariaceae (HdV-55A) and Coniochaeta cf. ligniaria (HdV-172). To provide an independent measure of spore abundance for individual taxa in aquatic sediments [310,311], spore concentrations are also shown, calculated as numbers of spores per cc. of wet sediment using the Lycopodium exotic marker technique [312]. Stable concentration rates indicate stable sedimentation rates, so that changes in frequencies reflect real changes in microfossil proportions in the assemblage.

Radiocarbon (AMS) dates are from Beta-Analytic, Miami, on pollen (organic) residues or peat, which previously have produced consistent results [311,313]. Alluvial sediment samples are avoided as these can produce anomalous dates [314]. Dates were calibrated using Calib 7.1 and IntCal13 [315]. Microfossil diagrams were constructed using TILIA [316].

\section{Results}

Microfossil data from four sites in the Taihu lowlands have been chosen to illustrate NPP evidence for increases in water depth that almost certainly correspond to flooding episodes. Their locations are shown on Figure 1. Results from Pingwang and Dianshan have been presented elsewhere [81,260], whereas data from Chuodun and Tianyilu have been published only in summary form [303]. A different sediment profile at Chuodun has been investigated by Long et al. [317]. The core lithostratigraphies of the four sites are shown in Table 1.

\subsection{Chuodun}

Chuodun lies in the northern part of the central Taihu plain to the east of Lake Yangcheng, at $31^{\circ} 24^{\prime} 16^{\prime \prime} \mathrm{N} ; 120^{\circ} 50^{\prime} 37^{\prime \prime} \mathrm{E}$, with a ground surface altitude of $2.5 \mathrm{~m}$ YSD (Yellow Sea Datum). The selected taxa microfossil diagram is presented as Figure 2. The site supported shallow marsh wetland habitats, as shown by the dominance of NPP taxa indicating reedswamp or wet semi-terrestrial conditions until around $1964 \mathrm{cal}$. BP when the more terrestrial indicators decline and are replaced by increasingly high percentages of open water algae, particularly Volvocaceae. Although the lithostratigraphy is clay throughout this section of the core, around $92 \mathrm{~cm}$ depth there is a change to less organic clay, marking the switch from a shallow marsh to deeper open water and fully aquatic environments at the site. Floating aquatic herbs including Myriophyllum and Potamogeton are present during the open water phase, suggesting quite eutrophic conditions presumably stimulated by the silt and nutrient content of the floodwaters, which is supported by the absence of 
Mougeotia, which prefers less eutrophic conditions. Total aquatic pollen frequencies are very low, however, indicating deep open water. The evidence from Chuodun suggests a flooding phase which increased water depth and therefore changed ecological communities at the site. Pollen concentration data show no rapid changes in sedimentation rate, and emphasise the abundance of Volvocaceae in the aquatic algal community.

Table 1. Core lithostratigraphy for the four sites.

\begin{tabular}{|c|c|c|}
\hline Site & Depth (m) & Description \\
\hline \multirow[t]{6}{*}{ Chuodun } & $0.00-0.30$ & Agricultural soil \\
\hline & $0.30-0.50$ & Yellow-grey firm silt and clay with organic matter \\
\hline & $0.50-0.95$ & Green-grey soft clay \\
\hline & $0.95-1.20$ & Black-grey soft clay \\
\hline & $1.20-1.38$ & Green-grey soft clay \\
\hline & $1.38-1.50$ & Hard clay \\
\hline \multirow[t]{4}{*}{ Tianyilu } & $0.00-0.50$ & Organic soil \\
\hline & $0.50-1.60$ & Brown-grey firm silt and clay, rich in organic matter and herbaceous roots \\
\hline & $1.60-2.00$ & Black-grey soft silt and clay \\
\hline & $2.00-2.30$ & Green-grey soft silt and clay \\
\hline \multirow[t]{10}{*}{ Dianshan } & $0.00-1.00$ & Agricultural soil \\
\hline & $1.00-1.15$ & Brown-yellow silt \\
\hline & $1.15-1.90$ & Green-grey mud \\
\hline & $1.90-2.20$ & Dark grey mud \\
\hline & $2.20-2.45$ & Green-grey highly organic mud \\
\hline & $2.45-2.60$ & Black peat \\
\hline & $2.60-2.65$ & Brown-black peaty mud \\
\hline & $2.65-3.05$ & Green-grey mud \\
\hline & $3.05-3.45$ & Grey mud with calcium carbonate patches \\
\hline & $3.45-3.50$ & Hard clay \\
\hline \multirow{9}{*}{ Pingwang } & $0.00-0.45$ & Organic soils \\
\hline & $0.45-1.10$ & Brown-yellow grey firm clay \\
\hline & $1.10-1.25$ & Black-grey soft clay \\
\hline & $1.25-1.80$ & Green-grey soft clay \\
\hline & $1.80-2.10$ & Brown-grey soft organic-rich clay \\
\hline & $2.10-3.10$ & Dark grey soft organic-rich clay with small shells in the upper part \\
\hline & $3.10-3.70$ & Green-grey soft silt and clay \\
\hline & $3.70-3.80$ & Black-brown peat \\
\hline & $3.80-4.00$ & Hard clay \\
\hline
\end{tabular}

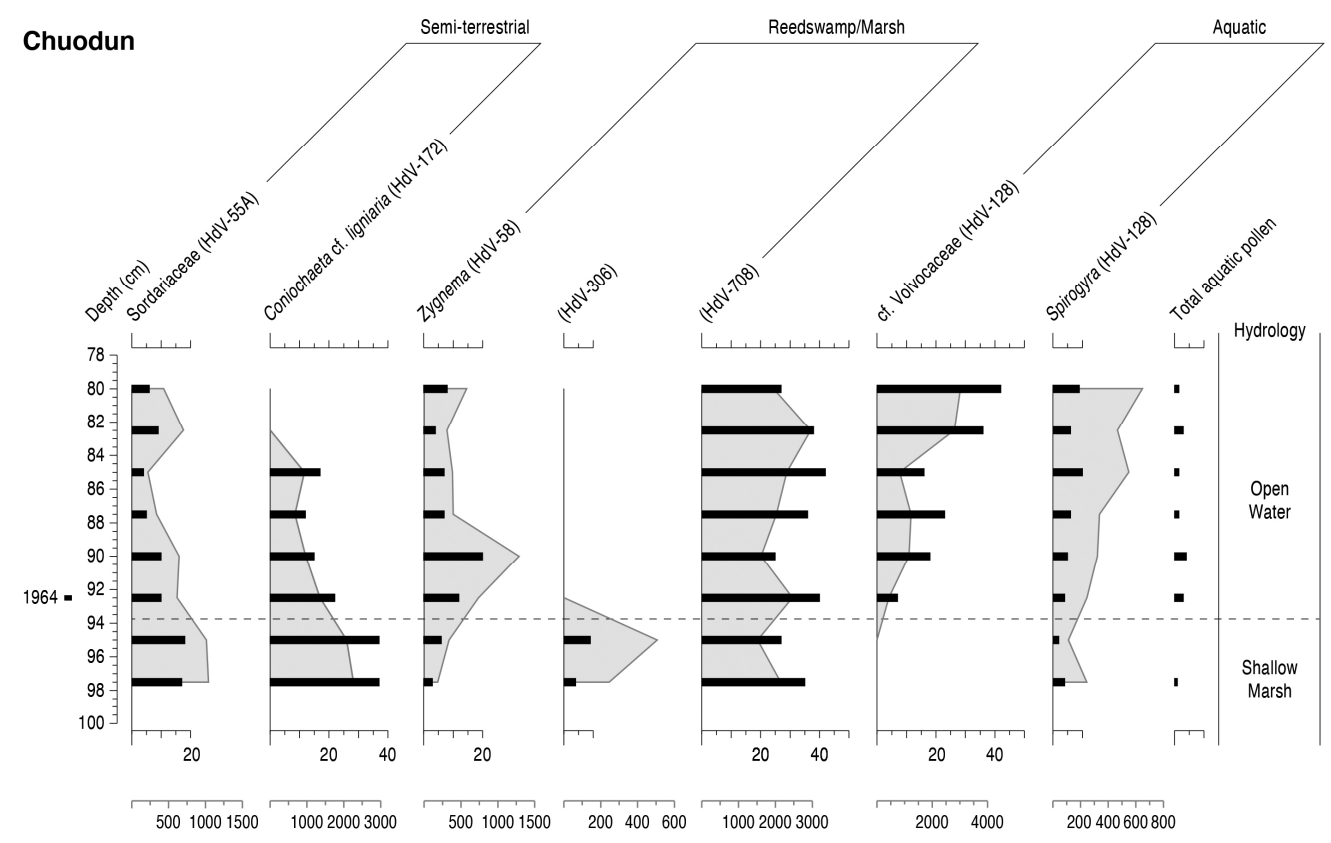

Figure 2. Frequencies of selected NPP taxa (histogram bars calculated as \% total NPPs) from Chuodun. A combined aquatic pollen curve is also shown, calculated as percentages of total land pollen. Pollen concentration values for the NPPs are shown as shaded curves (numbers of grains per cc. on the secondary $\mathrm{x}$-axis). 


\subsection{Tianyilu}

Tianyilu lies $600 \mathrm{~m}$ east of Siqian village, to the east of Lake Dianshan at $31^{\circ} 11^{\prime} 54^{\prime \prime} \mathrm{N}$; $121^{\circ} 6^{\prime} 40^{\prime \prime} \mathrm{E}$ with a ground surface altitude of $1.9 \mathrm{~m}$ YSD. The selected taxa microfossil diagram is presented as Figure 3. The site supported shallow marsh wetland habitats, as shown by the high frequencies of taxa indicative of wet surface marsh or shallow reedswamp, until $4000 \mathrm{cal}$. BP when the curves for fully aquatic taxa increase sharply, particularly Volvocaceae, Spirogyra and Mougeotia. Coniochaeta cf. ligniaria and HdV-708 are especially reduced, while Sordariaceae percentages decline more gradually, this general decomposer of plant material remained present in the locality. Pollen of floating and emergent aquatic plants occurs in low frequencies in this open water phase of the core, including Myriophyllum and Nelumbo, while Typha percentages are low to moderate. The total aquatic pollen curve comprises mainly Typha. The change in hydrological regime with significantly increased water depth at $4000 \mathrm{cal}$. BP was quite swift and represents one or more major fluvial flooding events. Concentration rates mirror the percentage changes well, and changes in taxa frequencies reflect changes in proportions in the assemblage, notably the switch from Coniochaeta to Volvocaceae as water levels deepened significantly. The age of $4000 \mathrm{cal}$. BP is significant in that it falls within a phase of climatic deterioration that has considerable evidence for flooding in most parts of the Yangtze catchment, as discussed below.

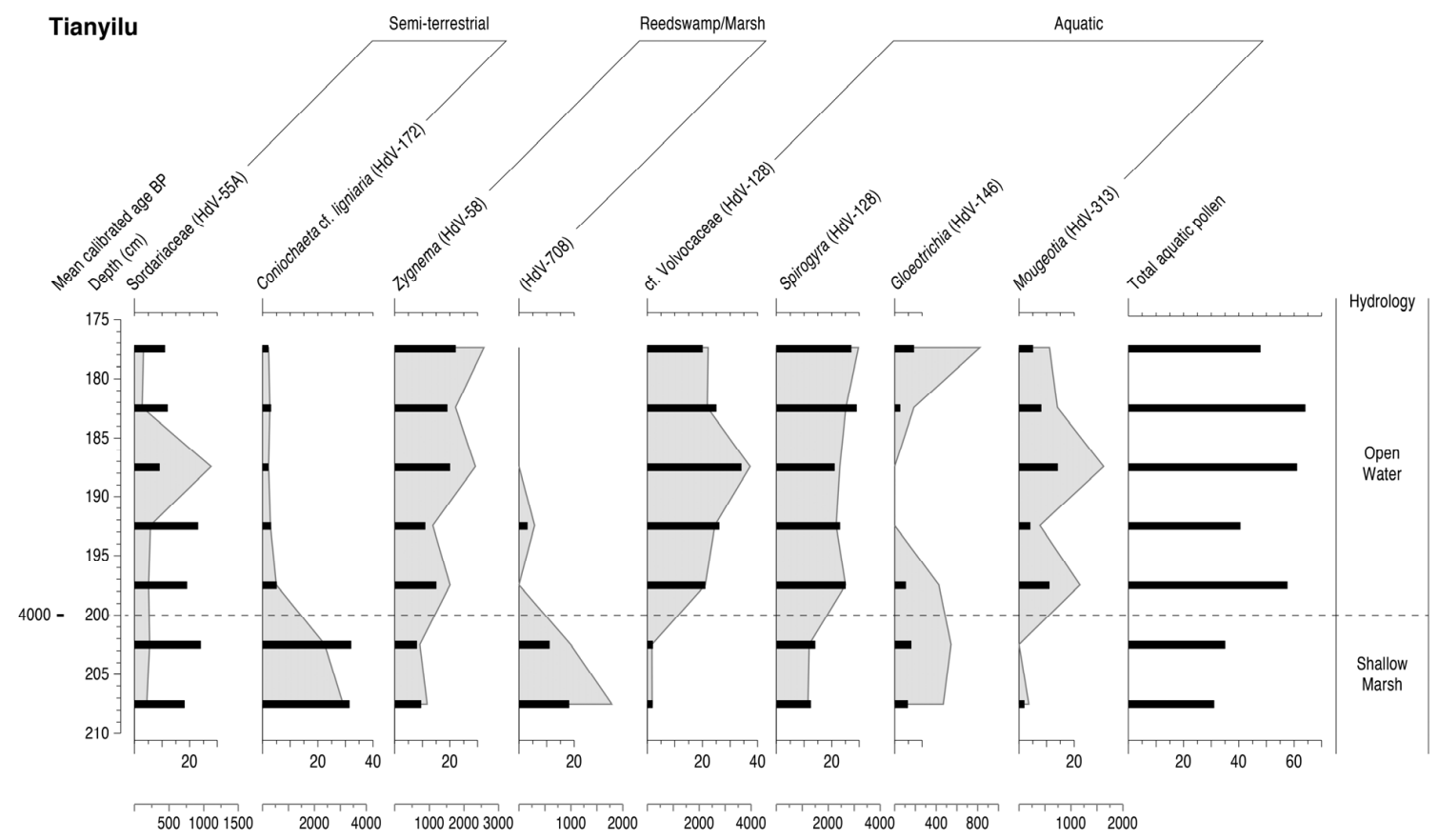

Figure 3. Frequencies of selected NPP taxa (histogram bars calculated as \% total NPPs) from Tianyilu. A combined aquatic pollen curve is also shown, calculated as percentages of total land pollen. Pollen concentration values for the NPPs are shown as shaded curves (numbers of grains per cc. on the secondary $\mathrm{x}$-axis).

\subsection{Dianshan}

Dianshan lies on the eastern shore of Dianshan Lake at $31^{\circ} 05^{\prime} 35^{\prime \prime} \mathrm{N} ; 120^{\circ} 59^{\prime} 0^{\prime \prime} \mathrm{E}$ with a ground surface altitude of $2 \mathrm{~m}$ YSD. The selected taxa microfossil diagram is presented as Figure 4. The site supported wetland marsh habitats depositing organic sediments in shallow reedswamp environments until around $1514 \mathrm{cal}$. BP when a transition to open water began. Reedswamp types HdV-306 and HdV-708 decline. Algal taxa increase with HdV-119 added to the assemblage, Gloeotrichia high and Volvocaceae percentages rising. Pollen of fully aquatic plants Nelumbo, Myriophyllum and Potamogeton occur in the open water phase of Figure 4 and record significant water depth, although Typha is the most common in the low total aquatic curve. The introduction of Pediastrum and 
Botryococcus, and peaks of Aphanizomenon, indicate that water depth continued to increase and some eutrophication occurred. The succession suggests perhaps two phases of fluvial flooding that changed shallow reedswamp to open water and then to increased water depth. Flooding was perhaps of repeated and major type but not extreme, as the shift to more aquatic systems was not sudden, but continuous. The location of the site adjacent to the large lake Dianshan will have made it susceptible to the effects of flooding and water level rises and it may have been subsumed within the lake [81]. The concentration curves are similar to the percentage changes, suggesting stable sedimentation rates, with Volvocaceae and Gloeotrichia the most abundant assemblage components.

\subsection{Pingwang}

Pingwang lies to the south-east of Lake Taihu at $30^{\circ} 57^{\prime} 30^{\prime \prime} \mathrm{N} ; 120^{\circ} 38^{\prime} 25^{\prime \prime}$ E, with a ground surface altitude of $1.6 \mathrm{~m}$ YSD. The selected taxa microfossil diagram is presented as Figure 5. The lower part of the core contains a thin peat which probably formed under higher saltmarsh conditions [260], followed by shallow water reedswamp and marsh as water tables continued to rise, shown by high frequencies of HdV-306, HdV-708 and semi-terrestrial fungal taxa. Some aquatic spores are present but do not dominate the assemblage and indicate the progression to shallow water. The semi-terrestrial and reedswamp taxa fall until about 7650 cal. BP when an increase in water depth occurs, with deeper water indicators Volvocaceae, Gloeotrichia and Pediastrum increasing. Floating aquatic pollen taxa Myriophyllum, Potamogeton and Nelumbo occur in low values, with Salvinia also present, but most of the low total aquatic pollen curve comprises Typha. Concentrations are generally high but mirror the percentage changes, indicating slow and stable sediment accumulation. Although not a dramatic change, the evidence suggests a significant increase in water depth, and possibly also eutrophication, that is most likely to represent substantial flooding. Evidence for floods of this age is not common in the lower Yangtze area, but this date corresponds to the date of 7700 cal. BP recorded by Song et al. [176] for a major flood in a core in the Yangtze valley just to the north of Nanjing, during a brief period of climatic deterioration.

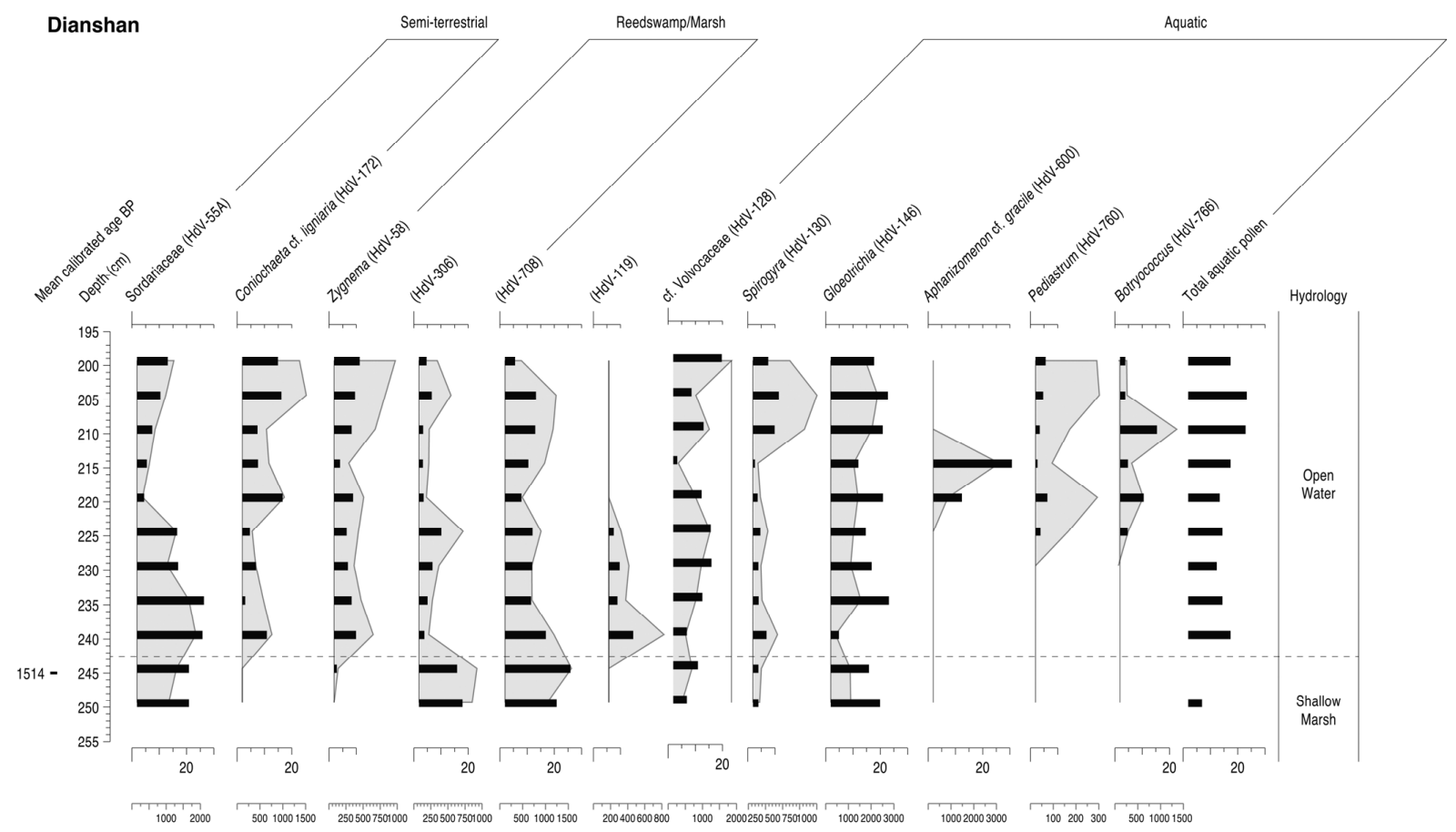

Figure 4. Frequencies of selected NPP taxa (histogram bars calculated as \% total NPPs) from Dianshan. A combined aquatic pollen curve is also shown, calculated as percentages of total land pollen. Pollen concentration values for the NPPs are shown as shaded curves (numbers of grains per cc. on the secondary $\mathrm{x}$-axis). 


\subsection{Summary}

These four examples from the Taihu lowland differ in the timing and magnitude of the evidence for flooding at each site, but they have demonstrated the ability of algal assemblages to recognize significant increases in water level that are not apparent in the lithostratigraphy, indicating rapid increases in water depth in already aquatic locations, although the ecological tolerances and preferences of these taxa are not exact and should be interpreted in assemblage terms, rather than individually. The curves for total aquatic pollen vary between the sites, although are never high, and mainly comprise Typha, common in the Taihu lowlands throughout the Holocene at a range of water depths.

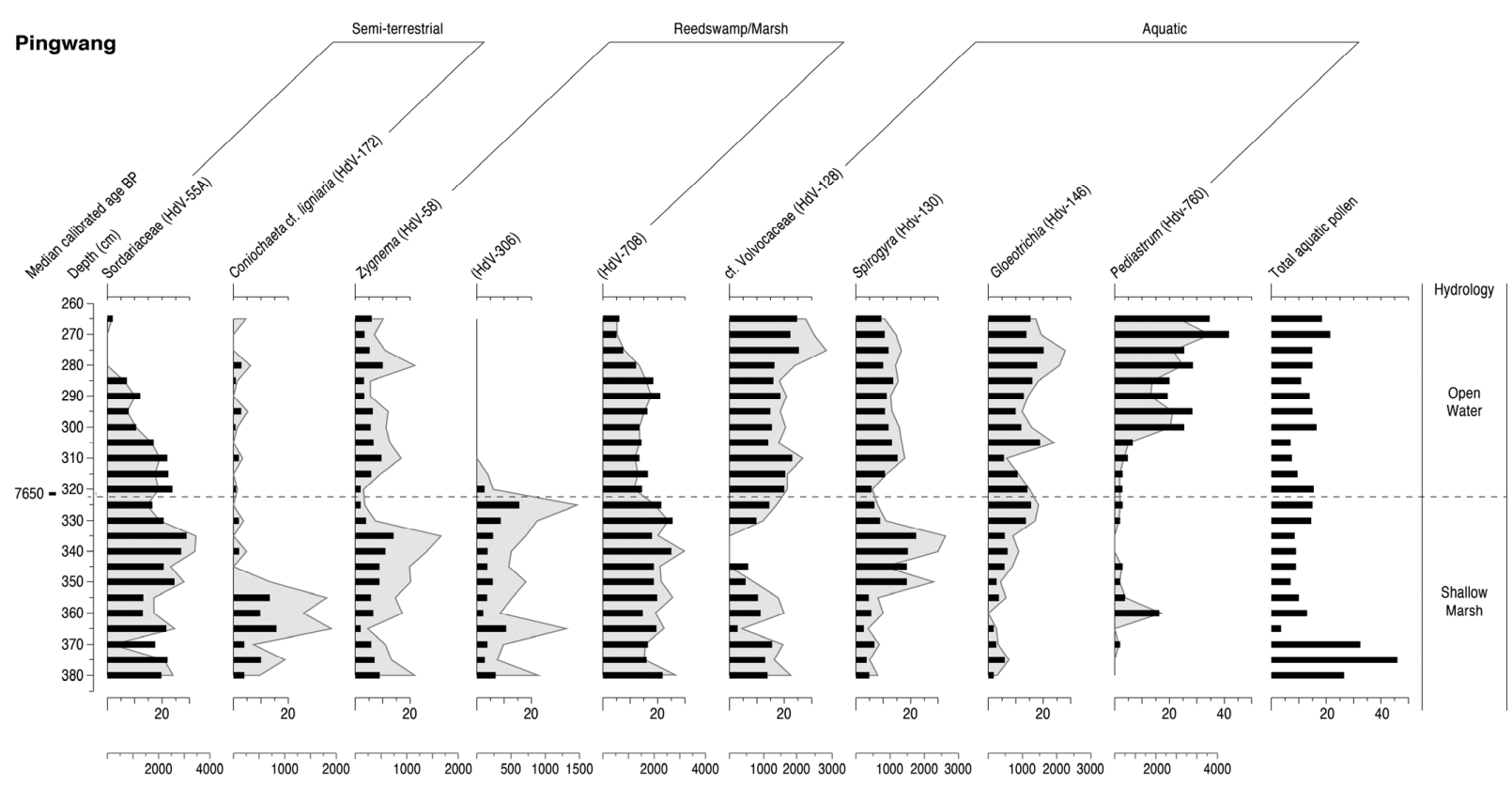

Figure 5. Frequencies of selected NPP taxa (histogram bars calculated as \% total NPPs) from Pingwang. A combined aquatic pollen curve is also shown, calculated as percentages of total land pollen. Pollen concentration values for the NPPs are shown as shaded curves (numbers of grains per cc. on the secondary $\mathrm{x}$-axis).

These aquatic pollen curves largely reflect Typha pollen taphonomy and the distance from the coring site of Typha beds. They do not reflect conditions at the sites themselves. These sites occur across a significant time range through most of the Holocene, and can be compared with the existing evidence for lower Yangtze floods, and all four fall within the age ranges for flooding phases in the Taihu plain discussed below, that are derived from synthesis of the published literature. They show that the use of aquatic algal microfossils can be an important additional proxy method in the study of floodplain hydrology and flood history, particularly when used in association with other techniques.

\section{Discussion}

\subsection{Hydrology of the Taihu Lowland Plain}

The overall postglacial lithostratigraphy of the Taihu lowland plain can be reconstructed from the many boreholes that have been completed there and in deltaic offshore cores, and comprises several facies, including lacustrine, riverine, deltaic, floodplain, marsh, lagoonal and estuarine-marine units [77,275,318-320]. Changes between these sedimentary units in site lithologies reflect changes in depositional environments and therefore in hydrological regimes. Freshwater floodplain sedimentation in the Yangtze delta lowland is governed by accretion rate, with high rates of fluvial sediment supply usually producing mineral-dominated deposits with low organic content [321], as most sedimentation in such environments occurs during low-intensity, regular river floods [26]. Most Yangtze delta deposits are therefore floodplain clays and silts of alluvial origin $[188,322,323]$ and the 
presence of in situ plant remains in most of them indicates steady accumulation of wetland sediments within shallow-water, hydrologically stable fen and swamp environments, as the delta gradually accreted vertically and prograded laterally. This type of autogenic hydrological succession through increasingly terrestrial wetland plant communities would have been the natural ecosystem in the lower Yangtze valley and the Taihu/delta lowlands [1].

Annual low-scale flooding from the river system would have had only moderate effects, raising the water table and laying down organic muds and clays in areas of lower altitude where semi-aquatic habitats would be maintained, and temporarily flooding more terrestrial land surfaces. In periods of low rainfall, or at slightly higher altitudes in the floodplain, fully organic peats would form under the process of terrestrialisation, and surface altitude would have been an important regulator of sedimentation type in the floodplain areas. Most sediments in the lower Yangtze and Taihu lowland represent these stable hydrological conditions [105], deposited in a range of wetland types with various water depths, but undergoing autogenic sedimentation.

The four examples shown in this paper, despite their differences in age, are alike in showing significant and sometimes rapid changes in local hydrology which must have been generated by major, or even extreme, flood events with significantly increased water depth causing a switch between a macrophyte-dominated marsh or shallow water fen-swamp state to an algae-dominated open water state, similar to hydrological successions in some recent shallow Yangtze lakes [7,15], including present-day Lake Taihu [116]. They also illustrate the types of evidence that can be diagnostic of such a rapid environmental change. Such major inputs of fluvial water during great flood events would suddenly alter the hydrology [324], increasing water depth and reversing the natural sedimentation regime, so that shallow aquatic marsh habitats would become deep, and semi-terrestrial wetlands would become fully aquatic, perhaps subsumed into the many already existing lakes of the floodplain, as the Pediastrum record [192] indicates for Pingwang. These sudden shifts in water depth would often be expressed in the sedimentary lithology, and lake sediments can be very good archives for preserving palaeoflood stratigraphies [325], using techniques such as magnetic measurements and grain-size analysis, as in Lake Taihu [168]. At already aquatic but shallow sites, however, the change might well be most observable in the biostratigraphy with deeper water micro-organisms becoming favoured, particularly algae, exacerbated by increased eutrophication as major amounts of sediment and nutrient-rich water were swept into the aquatic ecosystem, encouraging microphytic diversity and algal blooms for taxa including Pediastrum [196].

In the following sections we present the evidence for periods of hydrological stability and peat formation (Table 2) and for phases of major or extreme flood events (Table 3) in the lower Yangtze valley and Taihu lowlands/Ningshao plain, deduced from the published literature. A synthesis of the data is shown in Figure 6, divided into the phases when great floods were either common or rare. These broad phases can not be considered mutually exclusive, as exceptions to the general trend will occur within them, and they will be modified by future research. The existing dataset is large enough, however, to come to general conclusions regarding Holocene flood history in the study area. For correlation with climate, graphs of fluctuations in temperature (and monsoon precipitation) during the Holocene in the study area are also shown on Figure 6, derived from Shao et al. [239] at Shanbao Cave, the $\delta^{18} \mathrm{O}$ record closest to the Taihu lowland and at the same latitude, and from the Lianhua Cave [242], which has a record that continues up to the present day, unlike the Shanbao record which does not continue beyond about 2000 cal. BP.

\subsection{Terrestrialisation and Peat Formation}

Peat deposits indicate sedimentation at or near the wetland surface, deriving from plants of the 'in situ' marsh vegetation [204], and there are peat layers of various ages within the stratigraphic sequences of the lower Yangtze and Taihu lowlands, including some dated to the Lateglacial and to the very beginning of the Holocene [77,319], although the oldest is $32,325 \mathrm{cal}$. BP at Hemudu south of Hangzhou Bay at $36 \mathrm{~m}$ depth [188]. In a borehole 
offshore of the present Yangtze mouth Zhao et al. [326] recorded a floodplain freshwater marsh peat almost a metre thick that was dated as forming from 19,000 to 11,300 cal. BP, Stanley et al. [327] recorded a thin peat dated to about 15,800 cal. BP resting upon the stiff Pleistocene clay at core YZ-1, $30 \mathrm{~km}$ west of Shanghai, Li and Wang [318] recorded peats dated to about 13,500 cal. BP on the north bank of the Yangtze, Liu et al. [322] recorded a thin peat dated around 12,758 cal. BP at $36 \mathrm{~m}$ depth at Qidong at the seaward end of the delta, Liu et al. [188] reported a peat dated to 12,647 cal. BP at $30 \mathrm{~m}$ depth at Hemudu, while Qin et al. [328] recorded a peat dated about 12,568 cal. BP in a core offshore of the Yangtze delta. Zhang et al. [2] and Cheng and Ye [329] have reported peat at more than $18 \mathrm{~m}$ depth dated to 11,004 cal. BP at Beihu, south of Taihu on the upper Tiaoxi River near Hangzhou. Zhang et al. [79] recorded deep peat layers dated to 10,859 and 10,087 cal. BP, towards the end of the Lateglacial, at Xiaoshan in the incised Qiantang valley, as have Lin et al. $[78,330]$ of similar age.

It is clear that fluvial floodplain freshwater marsh environments have a very long history in the area of the present lower Yangtze and delta, many forming during the Lateglacial. Many more, however, have formed at various stages throughout the Holocene (Table 2). All such peats will have formed within floodplain, marsh-lacustrine or backbarrier lagoonal environments, but will represent near-surface autogenic organic sediment accumulation in a paludified freshwater marsh stage of hydroseral development [1], rather than in a deeper water aquatic environment. Their presence therefore implies phases in which water levels are not significantly elevated by extreme flood events. Examples of Lateglacial and earlier Holocene date are usually basal peats resting upon terrestrial, fluvial sediments, and will have formed in response to rising sea levels which were driving freshwater perimarine zone water tables higher [85,331], until waterlogging and organic sediment accumulation occurred in freshwater marsh and lagoonal areas. This sea-level rise created many of the shallow lakes that formed in the Taihu lowlands in the midHolocene $[109,114,248]$. The high water tables at this time caused many peats to accumulate (Table 2) in the Taihu lake area and around Hangzhou Bay in the early to mid-Holocene [332,333], but several more recent ones also occur $[173,246,332,334]$. In some cases, peats, some of which will have formed in the high upper saltmarsh zone [11], were then overtaken by rising marine waters which deposited estuarine clay and silt facies above them. Most were buried by freshwater and alluvial deposits, however, as sedimentation in floodplain wetlands in the mid-Holocene generally kept pace with any sea-level rise and chenier barrier ridges came into being $[74,103,104]$, both preventing marine penetration $[30,85]$.

The formation of marsh peats within floodplain wetlands requires conditions of low riverine input coupled with developed marsh vegetation and continuous organic accumulation [204]. The presence of peat in sediment columns in the Taihu lowlands must therefore indicate phases of low fluvial influence and vegetation-covered marshland surfaces. Periods during which such peat accumulation was dominant and fluvial sediments were rare will correspond to times when fluvial input was low, and so probably with low rainfall intensity. Dated examples of peat beds in the lower Yangtze and Taihu floodplain lowland are listed in Table 2. Derived from these data, periods during which peat formation was the norm are shown on Figure 6. It is clear that during the early and mid-Holocene, and into the late Holocene, hydrological conditions were largely stable, and while some significant flood events will have occurred, these were unusual and probably not of extreme strength. Low energy marsh, swamp and peat-forming wetland environments were the norm, with sediments of variable organic content, and these mid-Holocene conditions were very attractive for human settlement [335]. High sea level, and minor replenishment from fluvial sources, maintained freshwater floodplain marshes in most areas between the areas of open water represented by the floodplain's many lakes. There were, however, periods of exception to this stable norm when major floods did occur. 
Table 2. Chronology of phases of Holocene peat formation (surface water table) in the Taihu lowland/lower Yangtze area. Dates are in calibrated years BP. Age ranges may include several dates.

\begin{tabular}{|c|c|}
\hline Site & Median Age of Peat \\
\hline D2 [327] & 1050 \\
\hline Yaojiang [146] & 1321 \\
\hline T-1 [336] & 1350 \\
\hline Longnan [337] & $1500-1400$ \\
\hline Dianshan [81] & 1514 \\
\hline D2 [327] & 1700 \\
\hline Taihu plain [332] & $1710-1414$ \\
\hline Qingpu [313] & 2500 \\
\hline Yushan [98] & 2540 \\
\hline YZ-1 [327] & 2651 \\
\hline Taihu plain [332] & $3110-2818$ \\
\hline Dongjing [52] & $3177-3111$ \\
\hline Taihu plain [332] & 3630 \\
\hline Dongjing [52] & $3657-3639$ \\
\hline Guoyuancun [303] & $3795-3710$ \\
\hline Baiwaitan [52] & 4291 \\
\hline Maoshan [149] & 4464 \\
\hline Banxiangchan [52] & 4577 \\
\hline Liangzhu (LZ-1) [273] & 4620 \\
\hline Wuguishan [338] & 4630 \\
\hline Yangxi [30] & 4700 \\
\hline HB3 [339] & 4886 \\
\hline Hemudu [188] & $4924-4603$ \\
\hline Luojiang [5,311] & $4940-4620$ \\
\hline Yushan [340] & 4903 \\
\hline Taihu plain [332] & $5129-4346$ \\
\hline Liangzhu (LZ-4) [273] & 5175 \\
\hline Jingtoushan [341] & $5200-5000$ \\
\hline Tianluoshan [11] & 5326 \\
\hline Yaojiang [25] & 5386 \\
\hline Shisanzuqiao [332] & $5434-5347$ \\
\hline Tiaoxi valley [1] & 5445 \\
\hline Xiaofengyang [52] & 5517 \\
\hline Fengjing [52] & 5680 \\
\hline Wuguishan [338] & 5815 \\
\hline Hemudu [342] & 6255 \\
\hline Jingtoushan [341] & $6350-6200$ \\
\hline Hemudu [178] & $6470-6255$ \\
\hline Wujincheng [52] & 6494 \\
\hline Yaojiang [177] & 6509 \\
\hline Jingtoushan [341] & $6650-6500$ \\
\hline Xinjie [221] & 6713 \\
\hline Gehu Lake [30] & $6800-6500$ \\
\hline Hemudu 1501 [189] & 6932 \\
\hline Luotuodun [343] & 7000 \\
\hline Yuyao [344] & 7000 \\
\hline Xinjie [221] & 7210 \\
\hline Longnan [337] & 7410 \\
\hline Wujiabang [5] & 7509-7499 \\
\hline Taihu plain [332] & $7554-7134$ \\
\hline Beihu [2] & 7914 \\
\hline Beihuqiao [329] & $7989-7883$ \\
\hline Beihu [2] & 7990 \\
\hline Maqiao [52] & 8069 \\
\hline Hongkou [52] & 8156 \\
\hline Beihu [2] & 8348 \\
\hline Beihuqiao [329] & 8356 \\
\hline ZX-1 [327] & 8481 \\
\hline$Z X-1[250,323]$ & $8690-8512$ \\
\hline Pingwang [260] & c. 8850 \\
\hline Zhaoxiang [52] & $9072-8847$ \\
\hline HL81063 [339] & 10,027 \\
\hline
\end{tabular}




\subsection{Major Palaeofloods}

With the regularity and strength of recent flooding events as shown by historical records [345], it is to be expected that the basins and floodplains of the river were subject to major floods many times earlier in the Holocene, and there is considerable evidence that these have occurred. Clastic layers which represent flooding horizons occur in many early and mid-Holocene sediment sequences throughout the valley of the Yangtze [275] and in its tributary valleys [158,159,346-349], as well as in more recent, including historical, times [28] Many of these earlier clastic units have been confirmed as flood layers by sedimentological research $[159,164,350]$, and their ages, established by various dating techniques including radiocarbon, can be shown to correspond with periods of climatic change with higher rainfall and temperature fluctuation by analyses of several other forms of sedimentary archive $[130,351-354]$, particularly cave speleothem records $[161,228,239,242,353,355,356]$.

\subsubsection{The Lower Yangtze and Delta}

Tables 2 and 3 and Figure 6 show that the first three Holocene millennia were characterized by stable hydrological conditions, with gradually rising sea level encouraging rising water tables, surface soil waterlogging and the formation of peats in many low-lying parts of the Yangtze Delta and Hangzhou Bay area. While the Delta area was accreting rather than prograding between 10,000 and $7000 \mathrm{cal}$. BP, it was a warm, humid period with high rainfall as shown by biomarker and other research in the Yangtze valley [357-359]. It is only during the few centuries around the $8200 \mathrm{cal}$. BP cold and wet climatic deterioration [342] that there is evidence of major freshwater flooding from the Yangtze, labelled phase ' $a$ ' on Figure 6. Otherwise, the very few records of flooding is a reflection of the minor role the incised Yangtze river played in the area's hydrology in the early Holocene, with rising groundwater driven by sea-level rise leading to autochthonous lacustrine and peat deposition, often of the upper saltmarsh type as at Pingwang around $8850 \mathrm{cal}$. BP, in lagoonal and perimarine wetlands. During brief phases of less stable climate during this period, however, occasional floods did occur, such as the event around $7700 \mathrm{cal}$. BP recorded by Song et al. [176], which is reflected in the evidence for water depth rise at Pingwang at the same time.

After the Yangtze Delta floodplain was established and began to prograde after about 7000 cal. BP, river floods occurred more often, although variability of climate and rainfall allowed long periods of stability when peat still formed. Patalano et al. [249] have shown that climate between c.7500 and c.6500 cal. BP was relatively dry and, while peat could still form in the wetlands, floods did not occur (Table 3). A significant phase with major flood events occurred around the centuries around $6000 \mathrm{cal}$. BP, phase ' $b$ ' on Figure 6, again corresponding broadly with climatic deterioration and colder, wet conditions, as recorded at Hemudu south of Hangzhou Bay [342]. It was followed by a long period of humid climate [233] and hydrological stability with peat formation (Table 2), high lake levels [360], and only occasional floods, that lasted until about 4200 cal. BP. Overall, in the first six thousand years of the Holocene the lower Yangtze and Delta area can be categorized as hydrologically stable during the warm and wet Holocene climatic optimum [245], with relatively brief phases when major floods occurred and fluvial input was dramatically increased from that of the low-intensity seasonal EASM. 
Table 3. Chronology of Holocene fluvial flood events (rapid water level rises) in the Taihu lowland/lower Yangtze area. Dates are in calibrated years BP. Age ranges may include several dates. Some dates are reliable estimates based on other data.

\begin{tabular}{|c|c|}
\hline Site & Median Age of Flood Events \\
\hline Lake Taihu [168] & $400-0$ \\
\hline Dianshan [81] & 800 \\
\hline Jiang-nan [127] & $800-400$ \\
\hline Jiang-nan [127] & $1400-1200$ \\
\hline Longnan [337] & $1300-1200$ \\
\hline Chaohu Lake [135] & 1300 \\
\hline Shangshan [361] & 1710 \\
\hline Longnan [337] & $1800-1700$ \\
\hline Chuodun [303] & 1964 \\
\hline Chaohu Lake [135] & 2200,1800 \\
\hline Guangfulin [311] & 2400 \\
\hline Qingfeng [246] & 3900 \\
\hline Maqiao [362] & $4000-3800$ \\
\hline Maoshan [149] & $4000-3900$ \\
\hline Maoshan [154] & $4000-3900$ \\
\hline Chuodun [363] & c. 4000 \\
\hline Dadong [363] & c. 4000 \\
\hline Dasanjin [363] & c. 4000 \\
\hline Guoyuancun [363] & c. 4000 \\
\hline Liangzhu $[363,364]$ & c. 4000 \\
\hline Longtanhu [363] & c. 4000 \\
\hline Shuitianfan [363] & c. 4000 \\
\hline Tangwanli [363] & c. 4000 \\
\hline Tenghualuo [142] & c. 4000 \\
\hline Taihu plain [365] & c. 4000 \\
\hline Yuanjiadi [363] & c. 4000 \\
\hline Wangjiashan [363] & c. 4000 \\
\hline Xuxiang [363] & c. 4000 \\
\hline Yuecheng [363] & c. 4000 \\
\hline Tianyilu [303] & 4030 \\
\hline Yuhuicun [366] & 4100 \\
\hline XL [367] & 4200 \\
\hline Caoxieshan [246] & 5250 \\
\hline Baohuashan [246] & 5860 \\
\hline Fuquanshan [246] & 6020 \\
\hline Songze [246] & 6170 \\
\hline Huaihe valley [368] & $6250-5500$ \\
\hline Qingfeng [139] & $6400-5500$ \\
\hline Jingtoushan [341] & 6500 \\
\hline Pingwang [260] & 7650 \\
\hline HG01 [176] & 7700 \\
\hline Taihu plain [139] & $8100-7700$ \\
\hline Lower Yangtze [141] & $9200-8000$ \\
\hline
\end{tabular}

While some major flood events occurred in the Yangtze coastal lowlands in the early and mid-Holocene, it is with the great climatic deterioration that started around $4.2 \mathrm{ka}$ cal. BP [111,234], and which marks the transition to the colder Upper Holocene (Meghalayan) subepoch [261], that the most severe and repeated flood events occurred [136,145,225,265,268,369]. While much of China became more arid, field evidence as well as modelling [370] shows that the middle and lower Yangtze valley became wetter.

While the transition towards cooler conditions began around 6000, and especially after 5500 cal. BP [247,371,372], it is the major climatic shift around 4000 cal. BP, marked as phase ' $c$ ' on Figure 6, that marks the end of the warm and wet mid-Holocene climate optimum $[266,359,373]$ and the beginning of centuries of low temperatures, climatic variability and increased rainfall intensity [120,256,259]. Evidence of this major flooding phase 
is recorded in sedimentary sequences throughout the Yangtze catchment, including the delta lowlands (Table 3) as recorded at Tianyilu [303], and it clearly had major hydrological consequences $[181,268,374]$. Several sites experienced repeated flooding during this climatically transitional period [375], and some of the floods were very extreme events. Lake levels increased markedly at this time [278,376].
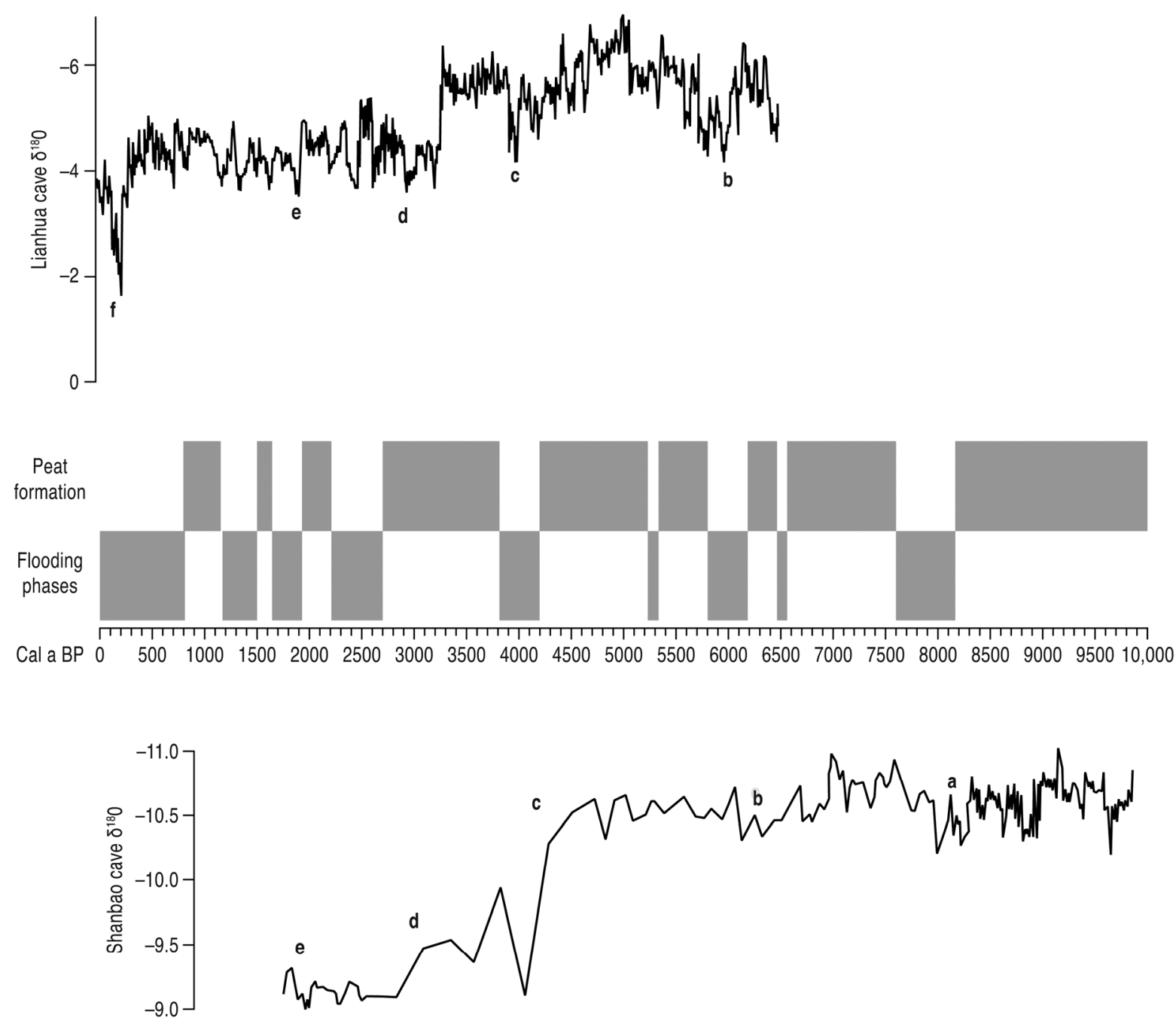

Figure 6. Phases of flooding and peat formation in the Lower Yangtze valley/Taihu lowland region, derived from Tables 2 and 3. Two graphs of temperature fluctuations (and monsoon precipitation) during the Holocene in eastern China are also shown, derived from Cosford et al. [242] at Lianhua Cave and Shao et al. [239] at Shanbao Cave, which is the $\delta^{18} \mathrm{O}$ record closest to the Taihu lowland and at the same latitude. Major climatic deterioration events are dated to (a) 8.2 (b) 6.2 (c) 4.2 (d) 2.8 (e) $1.8 \mathrm{cal}$. ka BP and (f) since c.500 cal. BP (Little Ice Age).

For more than a millennium after the end of phase ' $c$ ' on Figure 6 at about $3800 \mathrm{cal}$. BP there was relative hydrological stability in the study area, with many records of peat formation (Table 2) and no evidence of major flood events (Table 3). It corresponds to colder conditions under which the wetland communities of the Delta floodplain developed without exceptional fluvial input. Clearly shown on Figure 6, the next phase of major flooding in the lower Yangtze and Delta began at about 3000 to 2800 cal. BP, when climate deteriorated rapidly and became extremely variable, with rainfall volume and intensity increasing greatly $[244,278,358]$. This $2.8 \mathrm{ka}$ cal. BP event and the preceding one at $4.2 \mathrm{ka}$ cal. $\mathrm{BP}$ have been identified by Donges et al. [356] as one of the major non-linear climatic regime shifts in the Holocene, with very rapid climate change and high-amplitude variability in eastern China, with severe rainstorm events. 
Although climate change and the strength and character of the EASM remained a vital driver of rainfall in the Yangtze valley, with increased variability and rainstorm intensity in the Late Holocene [62], a complicating factor in palaeoflood history in the last three millennia has been the much increased impact of human activity in agriculture, deforestation and increasing runoff, erosion and flooding [34,64,65,67,68,311,377-379], particularly starting before $2500 \mathrm{cal}$. BP, in the centuries before the Qin dynasty [311] and having the effect of greatly increasing progradation rates of the Delta [72]. This human factor amplified the effects of climate in the last two millennia [135-137,380], a period during which climate, particularly rainfall, variability has been marked [62,124,221], especially so in the last half millennium and leading up to the very heavy rainfall intensity of modern times [381-383].

As Table 3 and Figure 6 show, from before 2500 to about 800 cal. BP relatively short periods of a few centuries' duration occurred, agreeing with the findings of Lu et al. [221] of extreme rainfall variability on centennial scales in the lower Yangtze, which had alternate dominance of flooding and peat formation with the centuries between 2000 and $1700 \mathrm{cal}$. BP (climatic phase ' $\mathrm{e}$ ') notable for cold and wet climate and major flood events [153], as recorded at Chuodun [303]. At Chaohu Lake between 2250 and 2100 cal. BP fine sand occurs in the lacustrine sediment column, signifying soil erosion caused by significant flooding, probably a combination of heavy rainfall and Yangtze floods [135], probably exacerbated by an increase in human impacts on the vegetation from this time onwards [384]. Major floods occurred in the Taihu area between about 1500 and 1200 cal. BP, with rising lake levels, as recorded at Dianshan [81]. Flooding has seriously affected the Yangtze Delta area in the last millennium [385] and Table 3 shows that since $800 \mathrm{cal}$. BP major flooding has been common under deteriorating climate $[81,127,128,168]$, with a particularly cold climate excursion in recent centuries represented as phase ' $\mathrm{f}$ ' in the Lianhua Cave evidence (Figure 6), corresponding to the 'Little Ice Age' cold phase [287]. Overall, Figure 6 shows that major flooding phases in the lower Yangtze and Taihu plain correspond well $[36,338]$ to periods of Holocene climatic instability and deterioration. The dates of the increases in water depth at the four Taihu Plain sites presented in this paper fall within the age ranges of major flood phases (Figure 6).

\subsubsection{The Upper and Middle Yangtze}

The main focus of this paper is the fluvial flood history of the lower Yangtze, and especially the delta lowlands around lake Taihu, but for comparative purposes it is important also to consider the flood history of the upper and middle reaches of the Yangtze valley and its tributary headwaters, and also because increased river flow and discharge in those areas of the catchment will have had an input into the situation downstream. Now much reclaimed for agriculture $[7,386]$, the major lakes and other wetlands in the mid-Yangtze area, particularly Dongting Lake and Poyang Lake, would have expanded and provided accommodation space for floodwater and sediment from upstream [8,134,360,376,387-392], but a considerable amount would still have entered the lower Yangtze valley, adding to overbank flooding and sedimentation in the study area. Records of major floods in the upper and mid-Yangtze region and in tributary headwaters are listed in Table 4. As with the Lower Yangtze, it is clear that flood events have occurred in the higher and middle reaches of the river at intervals throughout the Holocene [376,393-395]. Zhang et al. [351] have demonstrated that all sections of the Yangtze valley have had the same monsoon, and therefore climate, history and so have been subject to the same external environmental drivers. They should therefore have had similar Holocene flood histories.

Comparison of Tables 3 and 4 shows this mostly to be the case, although the middle and lower Yangtze appear to have suffered widespread great floods most particularly during the great climate deterioration and instability of 'Holocene Event 3 ' between 4200 and 3800 cal. BP [36,294,376,387,391], with flood clays deposited [376,393] and with multiple clastic layers at some sites, such as Hongqiaocun in the Upper Yangtze Chengdu Plain [170], experiencing several extreme flood events. It is clear that the Neolithic societies of the 
Middle Yangtze valley suffered major decline at this time [396,397], exemplified by the abandonment of the large Neolithic site of Chengtoushan on the west bank of Dongting Lake at 4000 cal. BP [369,398]. Many sites of the Baodun culture in the Chengdu Plain [399] were abandoned during this period. Further major flooding occurred at intervals during the similar, severe climatic deterioration that started around 2800 and lasted until $1700 \mathrm{cal}$. BP, for example the flood event at Majie in the Chengdu Plain [400]. It began a period of heavier rainfall [358] and increased flooding intensity that has lasted until the present day, as seen in the Poyang Lake area [401,402].

Table 4. Chronology of Holocene fluvial flood events (water level rises) in the upper and mid-Yangtze valley, and in Yangtze tributary headwaters. Dates are in calibrated years BP. Age ranges may include several dates. Some dates are reliable estimates based on other data.

\begin{tabular}{|c|c|}
\hline Site & Median Age of Flood Event \\
\hline Wufeng [349] & 400 \\
\hline Weibicun [160] & 600 \\
\hline Poyang [401] & $800-0$ \\
\hline Nanchang [288] & $840-772$ \\
\hline Weibicun [160] & $1000-800$ \\
\hline Luojiatan [153] & $1800-1700$ \\
\hline Liaowadian $[151,166]$ & 1800 \\
\hline Weibicun [160] & 1800 \\
\hline Zhangjiawan [403] & 1800 \\
\hline Xintancun [166] & 1900-1700 \\
\hline Weibicun [160] & 2200 \\
\hline Liaowadian $[151,166]$ & 2200 \\
\hline Majie [400] & 2610 \\
\hline Longgan Lake [278] & 2700 \\
\hline Hanjiang TJW [158] & c.3000 \\
\hline Weihe GCZ [158] & c.3100 \\
\hline Luojiatan $[153,166]$ & $3200-2800$ \\
\hline East Dongting [387] & 3900 \\
\hline Baodun [399] & $4000-3800$ \\
\hline Caitai [376] & c. 4000 \\
\hline Chengtoushan [369] & c. 4000 \\
\hline Longgan Lake [278] & c. 4000 \\
\hline Dongting [391] & c. 4000 \\
\hline Lajia [404] & c. 4000 \\
\hline Jianghan [171] & c. 4000 \\
\hline Hongqiacun [170] & c. 4000 \\
\hline Jinsha $[145,170]$ & c. 4000 \\
\hline Mangcheng [399] & c. 4000 \\
\hline Three Gorges [29] & c. 4000 \\
\hline Shuanghe [399] & c. 4000 \\
\hline Zhongba [148] & c. 4000 \\
\hline Yichang [405] & c. 4000 \\
\hline Yuxi [375] & c. 4000 \\
\hline Wulinji [376] & c. 4000 \\
\hline Zhongqiao $[119,170]$ & $4100-3800$ \\
\hline Zhongqiao $[119,170]$ & 4168 \\
\hline Tanjialing [294] & $4200-4000$ \\
\hline Luojiatan [153] & 4200 \\
\hline Zhongqiao [119] & $4900-4600$ \\
\hline Dongting [391] & 5800 \\
\hline T0403 Yuxi [295] & $6800-6300$ \\
\hline T0403 Yuxi [295] & $7600-7250$ \\
\hline Dajiuhu [354] & $9500-7500$ \\
\hline
\end{tabular}

References cited in Table 4 show that great floods were common in the period between 1900 and $1700 \mathrm{cal}$. BP and again from $1000 \mathrm{cal}$. BP to modern times. Lake levels in the 
middle Yangtze were at their highest during these Late Holocene flooding phases [277,278]. Extreme floods seem not to have occurred so much in the earlier Holocene, with examples dated to around the $8.2 \mathrm{ka}$ cal. BP event not present, although this might well just be an expression of the distribution of research effort and the availability of suitable sedimentary archives in those regions. Alternatively, the character of the $8.2 \mathrm{ka}$ event in China remains poorly understood [406], and it may be that the climate event was cold but without increased rainfall, precluding major floods. Future research might well yield data which modify this assessment.

\subsection{Influence of Hydrology on Human Settlement and Land Use}

It is clear that hydrology was the dominant environmental factor in the Taihu lowlands since the creation and development of the Yangtze delta, and while the wetland environments would have been attractive to human occupation and subsistence with many food and other resources, at times of hydrological instability a human presence amongst the floodplain wetlands might not have been viable. Much of the evidence for past fluvial activity in the Yangtze valley has therefore been derived from studies in environmental archaeology at ancient cultural sites and the relative hydrological stability (site formation and stable wetlands) and instability (river flooding and site abandonment) that occurred [52,136,143,258,369,391,407-410].

Evidence from sites in the area shows that in the Taihu-Hangzhou lowland many human settlements were located upon stable, organic marsh soils, some on surface peats [98,335] and others on piles in shallow water [342,411-413]. Here rice agriculture would be reliable and could be supplemented by the exploitation of wild plant and animal resources from the deeper water lakes and swamps that would have existed nearby [414-418]. During most of the Neolithic the Taihu plain supported dense and economically wealthy settlement [335], of which the sites at Kuahuqiao, Guangfulin, Hemudu, Majiabang, Siqian, Tianluoshan, Songze and Liangzhu are major examples [271,344,365]. In the later Neolithic around 4200 cal. BP freshwater flooding was apparently an increasing problem with earthworks for flood defence built at the Liangzhu site $[141,273,275,317]$. The dramatic increase in the incidence and magnitude of river valley flooding [135,136,369,374], where settlement and agriculture tended to be located, made people very vulnerable to rapid water level rise [143,399] and would force the abandonment of cultivated fields as well as settlements $[148,267,391]$, including in the Delta area [363,419].

Evidence shows that at the end of the Neolithic many sites were submerged by a dramatic elevation of water levels, by lake or river floods, or covered by rapidly growing marsh peat $[154,265,327]$, often with clastic flood layers, usually yellow clay and silt $[2,145,149,334,366,375]$, which can be up to a metre thick [275], sealing cultural occupation horizons [142,154,258,363,376,396,420-422]. These flooding horizons were devoid of archaeological material $[169,366,423,424]$, so that there appears to have been a cultural interruption as humans evacuated the area, with major sites such as Qingpu [313], Maqiao [362] and Liangzhu [364,419] abandoned. Zhang et al. [363] have listed several sites where such flooding horizons occur in the Taihu lowlands.

As occurred with agriculturally-based societies world-wide [425], in China cultures including the Liangzhu, Longshan, Qujialing and Shijiahe collapsed at this time [52,111,132, $142,294,366,376,409,426,427]$, perhaps following a period of decline [428], due to repeated extreme floods. Cultural interruption of this kind because of severe climate change is not confined to the Yangtze region, but has been noted at several sites on the Yellow River and elsewhere in northern China [169,429-431] at the time of the $4.2 \mathrm{ka}$ event, such as at Erlitou. As well as by flood events, however, in that region cultural disruption was sometimes caused by severe drought, as noted by Wu and Liu [265], caused by the weakening of the EASM $[170,234,429]$. In some cases, whole settlements could be at risk of destruction because of flood and debris flow after extreme rainfall at the time of the $4.2 \mathrm{ka}$ climate event, as in the headwaters of the Yellow River [432]. 
The locations of middle and late Neolithic human settlements of all sizes were also strongly influenced by hydrology, so that they were situated on higher ground near smaller water bodies [51,136,409], away from areas likely to be badly affected by flooding. For example, no settlements in the Chaohu lake basin in the lower Yangtze valley were below $10 \mathrm{~m}$ above sea level during that period, nor in the subsequent Shang and Zhou dynasties [372]. Changes in river and lake level, and even movement of river channels $[433,434]$, often forced relocation of Neolithic settlements to higher, safer ground [169,174,303,361,363,365,435], such as the small isolated uplands within the Taihu marshes or the coastal ridges to the east (Figure 1), a process which occurred in the middle as well as the lower reaches of the Yangtze [358,376,391,392,427]. Archaeological site distribution was therefore closely linked to environmental, mainly hydrological, factors and local topography [51,344,358,368,436-438]. Serious fluvial impacts occurred during post-Neolithic times also, with examples of increased frequency and severity of flooding disrupting settlement and food production, as at Guangfulin around $2400 \mathrm{cal}$. BP [311]. Bronze Age and Iron Age cultures in the Dajiuhu region of the central Yangtze valley [272] also came to an end during periods of major flooding [358]. Yin et al. [131] have discussed the impacts of climate change on dynastic history in the last two millennia, identifying centennial-scale warm and cold periods during which social and economic stability was maintained or destabilised $[439,440]$. This periodicity correlates well with the peat/flood phases shown on Tables 2 and 3 and Figure 6, illustrating the important role of great floods in Late Holocene cultural history in this part of the Yangtze valley, increasingly so in the last 800 years.

Although most flooding events that terminated occupation at cultural sites were fluvial, there are examples where marine flooding was responsible $[10,99,174,340,441]$, as at Wuguishan [338] and Yushan near the southern coast of Hangzhou Bay [98] where an inundation event caused by storms laid down thick muddy marine sand deposits. These seal Neolithic cultural levels, which occur within a wooded freshwater marsh peat, as do similar typhoon-induced coastal flood deposits at nearby Xiawangdu in the midHolocene [100]. Marine inundation also swamped cultural levels at the earlier Neolithic site of Kuahuqiao on the southern shore of the lower Qiantang River [301,442]. Although not the subject of this paper, marine inundation, especially driven by exceptional typhoon events, would have been an important force in the Yangtze delta area in the mid- and late Holocene.

\section{Conclusions}

Much of the lowland plain between the Yangtze River and Hangzhou Bay was created by fluvial activity due to progradation of the Yangtze delta from the early mid-Holocene onwards, and rests upon terrestrial sediments of pre-Holocene age, some of which are fluvial. Although also subject to marine influence, particularly in the early to mid-Holocene but also more recently, the varying input through time of fluvial water and suspended sediment discharge from the Yangtze has been dominant in governing the history of depositional regimes in this coastal plain since the mid-Holocene [23,209]. Combined with fluvial input from the other large rivers of the area, primarily the Qiantang but also the myriad of lesser drainage channels and creeks which cover the plain [1,5], deposits comprising minerogenic fluvial material dominate most of the sedimentary sequences in the Taihu lowlands, particularly to the east and south of the lake. Seasonal Yangtze floods must account for some of these exogenic clastic facies, but much of this material was introduced during great flood events, occasionally very extreme, which have occurred periodically during the Holocene. The Taihu lowland is the creation of the Yangtze.

Although allochthonous flood deposits are most important, also highly significant are the autochthonous deposits that have formed in the wetlands of the Taihu lowland-usually expressed as more organic units in the sediment column-within lakes, swamps, marshes and other freshwater aquatic systems. In particular, the occasional peat layers provide dateable marker horizons that signify periods of local hydrological stability and slower sedimentation when more extreme Yangtze floods were absent. Analysis of lithologies and 
microfossil content, particularly of aquatic plants and algae, from sites around Lake Taihu has allowed the reconstruction of water level movements that can be interpreted as proxies for greater or lesser flooding influence, especially from the Yangtze but also from other watercourses. Although occasional major floods could occur at any time, periods with many great floods were broadly around 8000, 6000, 4000 and after 2800 cal. BP, especially since c. $800 \mathrm{cal}$. BP, the later events often amplified by the hydrological effects of human activities in the catchment during a period of deteriorating climate.

Overall, the timing of major fluvial floods in the lower Yangtze and Taihu/Ningshao plains corresponds well with periods of Holocene climatic instability and deterioration, with six major phases of climate change and severe flooding recognized. Increased human settlement, its location and major land use in this coastal floodplain lowland were closely tied to local topography and to times when, mainly due to climatic factors, more extreme flooding events were rare, hydrological regimes were stable and ground surface conditions permitted extensive and intensive agriculture.

In this study, non-pollen palynomorphs, as they are generated very close to their site of deposition, have proven to be good diagnostic indicators of very local environmental conditions. At our four research sites, high frequencies of fungal spores correlated well with stable organic marsh soils with on-site vegetation and surface or shallow water, while aquatic algae that lived in the local water column increased in abundance when major flooding caused increases in water depth, replacing the fungal spores in the NPP assemblage. Although further analysis is required, it seems that the relative abundance of algal spores and algal assemblage composition in floodplain sediments can be used to recognize the occurrence of major freshwater flooding events. This will be of particular use in already aquatic environments, where the environment of deposition switches from shallow to deep water, and where other evidence of hydrological change, such as in sedimentary facies, does not occur.

Author Contributions: Conceptualization, Investigation and Methodology J.B.I. and Y.Z.; Writing J.B.I.; project administration, Y.Z.; Funding acquisition, Y.Z. All authors have read and agreed to the published version of the manuscript.

Funding: This research was funded by the Leverhulme Trust, UK (Grant Number F/000128/AL) and a Zijiang Visiting Professorship from the Shanghai Metropolitan Government awarded to Y. Zong.

Institutional Review Board Statement: Not applicable.

Informed Consent Statement: Not applicable.

Data Availability Statement: Data are presented in the paper.

Acknowledgments: We would like to thank the anonymous reviewers for their valuable comments on the manuscript. We are grateful to Chris Orton of the Cartography Unit, Geography Department, Durham University for producing the figures.

Conflicts of Interest: The authors declare no conflict of interest.

\section{References}

1. Chen, T.; Ryves, D.B.; Wang, Z.; Lewis, J.P.; Yu, X. Mid- to late Holocene geomorphological and hydrological changes in the south Taihu area of the Yangtze delta plain, China. Palaeogeogr. Palaeoclimatol. Palaeoecol. 2018, 498, 127-142. [CrossRef]

2. Zhang, Y.; Ye, W.; Ma, C.; Li, Y.; Li, C.; Zhu, L. Middle to late Holocene changes in climate, hydrology, vegetation and culture on the Hangjiahu Plain, southeast China. J. Palaeolimnol. 2020. [CrossRef]

3. Yan, Q.; Huang, S. Evolution of Holocene sedimentary environment in the Hangzhou-Jiaxing-Huzhou Plain. Acta Geogr. Sin. $1987,42,1-15$.

4. Yan, Q.; Shao, X. Evolution of shorelines along the north bank of Hangzhou Bay during the late stage of the Holocene transgression. Sci. China B 1989, 32, 347-360.

5. Qin, J.; Taylor, D.; Atahan, P.; Zhang, X.; Wu, G.; Dodson, J.; Zheng, H.; Itzstein-Davey, F. Neolithic agriculture, freshwater resources and rapid environmental changes on the lower Yangtze, China. Quat. Res. 2011, 75, 55-65. [CrossRef]

6. Chen, Z.; Song, B.; Wang, Z; Cai, Y. Late Quaternary evolution of the sub-aqueous Yangtze Delta, China: Sedimentation, stratigraphy, palynology, and deformation. Mar. Geol. 2000, 162, 423-441. [CrossRef] 
7. Yang, X.; Anderson, N.J.; Dong, X.; Shen, J. Surface sediment diatom assemblages and epilimnetic total phosphorous in large, shallow lakes of the Yangtze floodplain: Their relationships and implications for assessing long-term eutrophication. Freshw. Biol. 2008, 53, 1273-1290. [CrossRef]

8. Xie, C.; Huang, X.; Mu, H.; Yin, W. Impacts of land-use changes on the lakes across the Yangtze floodplain in China. Environ. Sci. Technol. 2017, 51, 3669-3677. [CrossRef]

9. An, S.; Li, H.; Guan, B.; Zhou, C.; Wang, Z.; Deng, Z.; Zhi, Y.; Liu, Y.; Xu, C.; Fang, S.; et al. China's natural wetlands: Past problems, current status and future challenges. Ambio 2007, 36, 335-342. [CrossRef]

10. Li, Y.; Wu, J.; Hou, S.; Shi, C.; Mo, D.; Liu, B.; Zhou, L. Palaeoecological records of environmental change and cultural development from the Liangzhu and Qujialing archaeological sites in the middle and lower reaches of the Yangtze River. Quat. Int. 2010, 227, 29-37. [CrossRef]

11. Li, C.; Zheng, Y.; Yu, S.; Li, Y.; Shen, H. Understanding the ecological background of rice agriculture on the Ningshao Plain during the Neolithic Age: Pollen evidence from a buried paddy field at the Tianluoshan cultural site. Quat. Sci. Rev. 2012, 35, 131-138. [CrossRef]

12. Xu, K.; Kong, C.; Liu, G.; Wu, C.; Deng, H.; Zhang, Y.; Zhuang, Q. Changes of urban wetlands in Wuhan, China, from 1987 to 2005. Prog. Phys. Geogr. 2010, 34, 207-220.

13. Chen, L.; Ren, C.; Zhang, B.; Li, L.; Wang, Z.; Song, K. Spatiotemporal dynamics of coastal wetlands and reclamation in the Yangtze Estuary during the past 50 years (1960s-2015). Chin. Geogr. Sci. 2017, 10, 1007. [CrossRef]

14. Sun, R.; Yao, P.; Wang, W.; Yue, B.; Liu, G. Assessment of wetland ecosystem health in the Yangtze and Amazon River basins. Int. J. Geo. Inf. 2017, 6, 81. [CrossRef]

15. Ge, Y.; Zhang, K.; Yang, X. Long-term succession of aquatic plants reconstructed from palynological records in a shallow freshwater lake. Sci. Total Environ. 2018, 643, 312-323. [CrossRef] [PubMed]

16. Hou, X.; Feng, L.; Tang, J.; Song, X.; Liu, J.; Zhang, Y.; Wang, J.; Xu, Y.; Dai, Y.; Zheng, Y.; et al. Anthropogenic transformation of Yangtze Plain freshwater lakes: Patterns, drivers and impacts. Remote Sens. Environ. 2020, 248, 111998. [CrossRef]

17. Du, J.; Yang, S.; Feng, H. Recent human impacts on the morphological evolution of the Yangtze River delta foreland: A review and new perspectives. Estuar. Coast. Shelf Sci. 2016, 181, 160-169. [CrossRef]

18. Nakayama, T.; Shankman, D. Impact of the Three-Gorges Dam and water transfer project on Changiiang floods. Glob. Planet. Chang. 2013, 100, 38-50. [CrossRef]

19. Yang, Z.; Wang, H.; Saito, Y.; Milliman, J.D.; Xu, K.; Qiao, S.; Shi, G. Dam impacts on the Changjiang (Yangtze) River sediment discharge to the sea: The past 55 years and after the Three Gorges Dam. Water Resour. Res. 2006, 42, W04407. [CrossRef]

20. Yang, S.; Milliman, J.D.; Xu, K.; Deng, B.; Zhang, X.; Luo, X. Downstream sedimentary and geomorphic impacts of the three Gorges dam on the Yangtze River. Earth-Sci. Rev. 2014, 138, 469-486. [CrossRef]

21. Yang, H.; Yang, S.; Yu, K.; Milliman, J.D.; Wang, H.; Yang, Z.; Chen, Z.; Zhang, C. Human impacts on sediment in the Yangtze River: A review and new perspectives. Glob. Planet. Chang. 2018, 162, 8-17. [CrossRef]

22. Wang, Z.; Li, Y.; He, Y. Sediment budget of the Yangtze River. Wat. Resour. Res. 2007, 43, W04401. [CrossRef]

23. Chen, $X$. An integrated study of sediment discharge from the Changjiang River, China, and the Delta development since the mid-Holocene. J. Coast. Res. 1996, 12, 26-37.

24. Chen, X. Changjiang (Yangtze) River delta, China. J. Coast. Res. 1998, 14, 838-858.

25. Liu, Y.; Sun, Q.; Fan, D.; Dai, B.; Ma, F.; Xu, L.; Chen, J.; Chen, Z. Early to Middle Holocene sea level fluctuation, coastal progradation and the Neolithic occupation in the Yaojiang Valley of southern Hangzhou Bay, Eastern China. Quat. Sci. Rev. 2018, 189, 91-104. [CrossRef]

26. Song, B.; Li, Z.; Saito, Y.; Okuno, J.I.; Lu, A.; Hua, D.; Li, J.; Li, Y.; Nakashima, R. Initiation of the Changjiang (Yangtze) delta and its response to the mid-Holocene sea level change. Palaeogeogr. Palaeoclimatol. Palaeoecol. 2013, 388, 81-97. [CrossRef]

27. Wang, Z.; Saito, Y.; Zhan, Q.; Nian, X.; Pan, D.; Wang, L.; Chen, T.; Xie, J.; Li, X.; Jiang, X. Three-dimensional evolution of the Yangtze River mouth, China during the Holocene: Impacts of sea level, climate and human activity. Earth-Sci. Rev. 2018, 185, 938-955. [CrossRef]

28. Liu, P. The cyclic geography study on the historical floods in the Yangtze River. Adv. Earth Sci. 2000, 15, 503-508.

29. Zhan, D.; Xie, Y. Study on Ancient Floods; China Water Resources and Hydropower Press: Beijing, China, 2001.

30. Zhu, C.; Zheng, C.; Ma, C.; Yang, X.; Gao, X.; Wang, H.; Shao, J. On the Holocene sea-level highstand along the Yangtze delta and Ningshao plain, East China. Chin. Sci. Bull. 2003, 48, 2672-2683. [CrossRef]

31. Zong, Y. Mid-Holocene sea-level highstand along the southeast coast of China. Quat. Int. 2004, 117, 55-67. [CrossRef]

32. Gu, Y.; Liu, H.; Qin, Y. Postglacial transgression maximum documented by the core sediments of Xixi Wetland, East China. Quat. Int. 2017, 436, 84-95. [CrossRef]

33. Xiong, H.; Zong, Y.; Li, T.; Long, T.; Huang, G.; Fu, S. Coastal GIA processes revealed by the early to middle Holocene sea-level history of east China. Quat. Sci. Rev. 2020, 233, 106249. [CrossRef]

34. Yu, F.; Chen, Z.; Ren, X.; Yang, G. Analysis of historical floods on the Yangtze River, China: Characteristics and explanations. Geomorphology 2009, 113, 210-216. [CrossRef]

35. Zhan, W.; Yang, S.; Liu, X.; Li, J.; Choi, M. Reconstruction of flood events over the last 150 years in the Changjiang reaches. Chin. Sci. Bull. 2010, 55, 2268-2274. [CrossRef] 
36. Zhou, X.; Yu, X. Correlation studies on palaeoflood events in the drainage area of Yangtze and Yellow River during the Holocene. J. Earth Environ. 2013, 4, 1428-1436. (In Chinese)

37. Ge, Z. The response of Holocene extreme floods in the Upper Yangtze River to changes of southwest monsoon. J. Geophys. Res. 2009, 3, 592-600. (In Chinese)

38. Yang, D.; Yu, G.; Xie, Y.; Zhan, D.; Li, Z. Sedimentary records of large Holocene floods from the middle reaches of the Yellow River, China. Geomorphology 2000, 33, 73-88. [CrossRef]

39. Yang, X.; Xia, Z.; Cui, Z. Holocene extreme floods and its sedimentary characteristic in the upper reaches of the Yellow River. Quat. Res. 2005, 21, 81-85.

40. Yao, P.; Huang, C.; Pang, J.; Zha, X.; Li, X. Palaeoflood hydrological studies in the middle reaches of the Beiluohe River. Acta Geogr. Sin. 2008, 63, 1198-1206. (In Chinese)

41. Huang, C.; Pang, J.; Zha, X.; Zhou, Y.; Su, H.; Li, Y. Extraordinary floods of 4100-4000 a BP recorded at the Late Neolithic ruins in the Jinghe River Gorges, middle reach of the Yellow River, China. Palaeogeogr. Palaeoclimatol. Palaeoecol. 2010, 289, 1-9. [CrossRef]

42. Huang, C.; Pang, J.; Zha, X.; Su, H.; Jia, Y. Extraordinary floods related to the climatic event at 4200 a BP on the Qishuihe River, middle reaches of the Yellow River, China. Quat. Sci. Rev. 2011, 30, 460-468. [CrossRef]

43. Huang, C.; Pang, J.; Zha, X.; Zhou, Y.; Su, H.; Zhang, Y.; Wang, H.; Gu, H. Holocene palaeoflood events recorded by slackwater deposits along the lower Jinghe River valley, middle Yellow River basin, China. J. Quat. Sci. 2012, 27, 485-493. [CrossRef]

44. Liu, T.; Huang, C.; Pang, J.; Zhou, Y.; Zhang, Y.; Ji, L.; Shang, R. Extraordinary hydro-climatic events during $1800-1600$ yr BP in the Jin-Shaan Gorges along the middle Yellow River, China. Palaeogeogr. Palaeoclimatol. Palaeoecol. 2014, 410, 143-152. [CrossRef]

45. Zhang, Y.; Huang, C.; Tan, Z.; Chen, Y.; Qiu, H.; Huang, C.; Li, Y.; Zhang, Y.; Li, X.; Shulmeister, J.; et al. Prehistoric and historic overbank floods in the Luoyang Basin along the Luohe River, middle Yellow River basin, China. Quat. Int. 2019, 521, 118-128. [CrossRef]

46. Ishii, Y.; Hori, K.; Momohara, A. Middle to Late Holocene flood activity estimated from loss on ignition of peat in the Ishikari lowland, northern Japan. Glob. Planet. Chang. 2017, 153, 1-15. [CrossRef]

47. Suzuki, Y.; Tada, R.; Nagashima, K.; Nakagawa, T.; Gotanda, K.; Haraguchi, T.; Schlolaut, G. Extreme flood events and their frequency variations during the middle to late-Holocene recorded in the sediment of Lake Suigetsu, central Japan. Holocene 2020. [CrossRef]

48. Lim, J.; Lee, J.; Hong, S.; Kim, J. Late Holocene flooding records from the floodplain deposits of the Yugu river, South Korea. Geomorphology 2013, 180-181, 109-119. [CrossRef]

49. Lim, J.; Lee, J.; Hong, S.; Kim, J.; Yi, S.; Nahm, W. Holocene changes in flooding frequency in South Korea and their linkage to centennial-to-millennial-scale El Niño-Southern Oscillation activity. Quat. Res. 2017, 87, 37-48. [CrossRef]

50. Park, J.; Park, J.; Yi, S.; Kim, J.; Lee, E.; Choi, J. Abrupt Holocene climate shifts in coastal East Asia, including the 8.2 ka, 4.2 ka, and $2.8 \mathrm{ka}$ BP events, and societal responses on the Korean peninsula. Sci. Rep. 2019, 9, 10806. [CrossRef]

51. Li, B.; Liu, H.; Wu, L.; McCloskey, T.A.; Li, K.; Mao, L. Linking the vicissitude of Neolithic cities with mid Holocene environment and climate changes in the middle Yangtze River, China. Quat. Int. 2014, 321, 22-28. [CrossRef]

52. Wu, L.; Zhu, C.; Zheng, C.; Li, F.; Wang, X.; Li, L.; Sun, W. Holocene environmental change and its impacts on human settlement in the Shanghai area, East China. Catena 2014, 114, 78-89. [CrossRef]

53. Duan, C.; Gan, X.; Wang, J.; Chien, P. Relocation of civilization centres in ancient China: Environmental factors. Ambio 1998, 27, 572-575.

54. Zhang, Z.; Tian, H.; Cazelles, B.; Kausrud, K.L.; Bräuning, A.; Guo, F.; Stenseth, N.C. Periodic climate cooling enhanced natural disasters and wars in China during AD 10-1900. Proc. R. Soc. B Biol. Sci. 2010, 277, 3745-3753. [CrossRef] [PubMed]

55. Xiao, L.; Fang, X.; Zheng, J.; Zhao, W. Famine, migration and war: Comparison of climate change impacts and social responses in North China between the late Ming and late Qing dynasties. Holocene 2015, 25, 900-910. [CrossRef]

56. Lee, H.; Zhang, D.; Pei, Q.; Jia, X.; Yue, R. Quantitative analysis of the impact of droughts and floods on internal wars in China over the last 500 years. Sci. China D Earth Sci. 2017, 60, 2078-2088. [CrossRef]

57. Pei, Q. Migration for survival under natural disasters: A reluctant and passive choice for agriculturalists in historical China. Sci. China D Earth Sci. 2017, 60, 2089-2096. [CrossRef]

58. Wu, Q.; Zhao, Z.; Liu, L.; Granger, D.E.; Wang, H.; Cohen, D.J.; Wu, X.; Ye, M.; Bar-Yosef, O.; Lu, B.; et al. Outburst flood at 1920 BCE supports historicity of China's Great Flood and the Xia dynasty. Science 2016, 353, 579-582. [CrossRef]

59. Wang, H.; Tong, K.; Hu, G.; Wang, P.; Li, D.; Huang, J.; Cao, G.; Zhang, J.; Chen, J. Dam and megafloods at the First Bend of the Yangtze River since the last Glacial Maximum. Geomorphology 2021, 107491. [CrossRef]

60. Jiang, R.; King, L.; Gemmer, M.; Kundzewicz, Z.W. (Eds.) Climate Change and Yangtze Floods; Science Press: Beijing, China, 2004.

61. Ding, Y.; Chan, J. The East Asian summer monsoon: An overview. Meteorol. Atmos. Phys. 2005, 89, 117-142.

62. Chen, F.; Xu, Q.; Chen, J.; Birks, H.J.B.; Liu, J.; Zhang, S.; Jin, L.; An, C.; Telford, R.J.; Cao, X.; et al. East Asian summer monsoon precipitation variability since the last deglaciation. Sci. Rep. 2015, 5, 11186. [CrossRef]

63. Kundzewicz, Z.W.; Huang, J.; Pinskwar, I.; Su, B.; Szwed, M.; Jiang, T. Climate variability and floods in China-A review. Earth-Sci. Rev. 2020, 211, 103434. [CrossRef]

64. Ren, G. Decline of the mid-to late Holocene forests in China: Climatic change or human impact? J. Quat. Sci. 2000, 15, $273-281$. [CrossRef]

65. Yin, H.; Li, C. Human impact on floods and flood disasters on the Yangtze River. Geomorphology 2001, 41, 105-109. [CrossRef] 
66. Wang, Z.; Li, M.; Zhang, R.; Zhuang, C.; Liu, Y.; Saito, Y.; Xie, J.; Zhao, B. Impacts of human activity on the late-Holocene development of the subaqueous Yangtze delta, China, as shown by magnetic properties and sediment accumulation rates. Holocene 2011, 21, 393-407. [CrossRef]

67. Chen, W.; Song, B.; Shu, J.; Jin, C.; Wang, W. Vegetation history with implication of climate changes and human impacts over the last 9000 years in the Lake Nanyi area, Anhui Province, East China. Palaeoworld 2020. [CrossRef]

68. Guo, Y.; Mao, L.; Mo, D.; Shu, J.; Guo, A. Vegetation dynamics and human activities over the past 1300 years revealed by pollen record at the Tongguan kilns, lower Xianjiang River, China. Quat. Int. 2021, 577, 139-146. [CrossRef]

69. Wang, P.; Shen, H. The Changjiang (Yangtze) River Delta: A review. In Deltas of the World; Kay, R., Ed.; American Society of Civil Engineers: New York, NY, USA, 1993; pp. 16-29.

70. Hori, K.; Saito, Y. An early Holocene sea-level jump and delta initiation. Geophys. Res. Lett. 2007, 34, L18401. [CrossRef]

71. Saito, Y.; Yang, Z.; Hori, K. The Huanghe (Yellow River) and Changjiang (Yangtze River) deltas: A review on their characteristics, evolution and sediment discharge during the Holocene. Geomorphology 2001, 41, 219-231. [CrossRef]

72. Hori, K.; Saito, Y.; Zhao, Q.; Cheng, X.; Wang, P.; Sato, Y.; Li, C. Sedimentary facies and Holocene progradation rates of the Changjiang (Yangtze) delta, China. Geomorphology 2001, 41, 233-248. [CrossRef]

73. Qin, J.; Wu, G.; Zheng, H.; Zhou, Q. The palynology of the first Hard Clay layer (late Pleistocene) from the Yangtze delta, China. Rev. Palaeobot. Palynol. 2008, 149, 63-72. [CrossRef]

74. Fan, D.; Wu, Y.; Zhang, Y.; Burr, G.; Huo, M.; Li, J. South flank of the Yangtze Delta: Past, present and future. Mar. Geol. 2017, 392, 78-93. [CrossRef]

75. Wang, J.; Chen, F.; Yang, B.; Chen, J. New advances in research on the Little Ice Age climate change. Adv. Clim. Chang. Res. 2006, 2, 21-27, (In Chinese with English abstract).

76. Zhang, G.; Li, C. Sources of sediments filling the Qiantangjiang estuary incised valley since the Last Glaciation. Chin. Sci. Bull. 1998, 43, 1280-1284. [CrossRef]

77. Li, C.; Wang, P.; Sun, H.; Zhang, J.; Fan, D.; Deng, B. Late Quaternary incised-valley fill of the Yangtze delta (China): Its stratigraphic framework and evolution. Sediment. Geol. 2002, 152, 133-158. [CrossRef]

78. Lin, C.; Zhuo, H.; Gao, S. Sedimentary facies and evolution in the Qiantang River incised valley, eastern China. Mar. Geol. 2005, 219, 235-259. [CrossRef]

79. Zhang, X.; Lin, C.; Dalrymple, R.W.; Gao, S.; Li, Y. Facies architecture and depositional model of a macrotidal incised-valley succession (Qiantang River estuary, eastern China), and differences from other macrotidal systems. GSA Bull. 2014, 126, 499-522. [CrossRef]

80. Wang, Z.; Zhuang, C.C.; Saito, Y.; Chen, J.; Zhan, Q.; Wang, X.D. Early mid-Holocene sea-level change and coastal environmental response on the southern Yangtze delta plain, China: Implications for the rise of Neolithic culture. Quat. Sci. Rev. 2012, 35, 51-62. [CrossRef]

81. Innes, J.B.; Zong, Y.; Xiong, H.; Wang, Z.; Chen, Z. Pollen and non-pollen palynomorph analyses of Upper Holocene sediments from Dianshan, Yangtze coastal lowlands, China: Hydrology, vegetation history and human activity. Palaeogeogr. Palaeoclimatol. Palaeoecol. 2019, 523, 30-47. [CrossRef]

82. Stanley, D.J.; Warne, A.G. Worldwide initiation of Holocene marine deltas by deceleration of sea-level rise. Science 1994, 265, 228-231. [CrossRef]

83. Sun, S.; Wu, Y.; Dong, B. Evolution and modern sediment of the Taihu Lake. Sci. China Ser. B 1987, 12, 78-86.

84. Hong, X. Origin and evolution of the Taihu Lake. Mar. Geol. Quat. Geol. 1991, 11, 87-99. (In Chinese)

85. Zong, Y.; Innes, J.B.; Wang, Z.; Chen, Z. Mid-Holocene coastal hydrology and salinity changes in the east Taihu area of the lower Yangtze wetlands, China. Quat. Res. 2011, 76, 69-82. [CrossRef]

86. Chen, X.; Zong, Y. Coastal erosion along the Changjiang deltaic shoreline, China: History and prospective. Estuar. Coast. Shelf Sci. 1998, 46, 733-742. [CrossRef]

87. Xin, Z.; Xie, Z. Construction of the simulating model for geomorphic evolution on the Yangtze delta, China. Acta Geogr. Sin. 2006, 61, 549-560. (In Chinese)

88. Bevington, A.E.; Twilley, R.R. Island edge morphodynamics along a chronosequence in a prograding deltaic wetland. J. Coast. Res. 2018, 34, 806-817. [CrossRef]

89. Yang, S.; Ding, P.; Chen, S. Changes in progradation rate of the tidal flats at the mouth of the Changjiang (Yangtze) River, China. Geomorphology 2001, 38, 167-180. [CrossRef]

90. Yang, S.; Xu, K.; Milliman, J.D.; Yang, H.; Wu, C. Decline of Yangtze River water and sediment discharge: Impact from natural and anthropogenic changes. Sci. Rep. 2015, 5, 12581. [CrossRef] [PubMed]

91. Yang, S.; Milliman, J.D.; Li, P.; Xu, K. 50,000 dams later: Erosion of the Yangtze river and its delta. Glob. Planet. Chang. 2011, 75, 14-20. [CrossRef]

92. Liu, J.; Xu, K.; Li, A.; Milliman, J.D.; Velozzi, D.M.; Xiao, S.; Yang, Z. Flux and fate of Yangtze River sediment delivered to the East China Sea. Geomorphology 2007, 85, 208-224. [CrossRef]

93. Chen, X.; Yan, Y.; Fu, R.; Dou, X.; Zhang, E. Sediment transport from the Yangtze River, China, into the sea over the post-Three Gorge Dam period: A discussion. Quat. Int. 2008, 186, 55-64. [CrossRef]

94. Tan, C.; Huang, B.; Liu, F.; Yang, Q.; Jiang, C.; Zhang, S. Transformation of the three largest Chinese river deltas in response to the reduction of sediment discharges. J. Coast. Res. 2016, 32, 1402-1416. [CrossRef] 
95. Gao, J.; Shi, Y.; Sheng, H.; Kettner, A.J.; Yang, Y.; Jia, J.; Wang, Y.; Li, J.; Chen, Y.; Zou, X.; et al. Rapid response of the Changjiang (Yangtze) River and East China Sea source-to-sink conveying system to human induced catchment perturbations. Mar. Geol. 2019, 414, 1-17. [CrossRef]

96. Zhao, Y.; Zou, X.; Liu, Q.; Xu, M.; Yao, Y. Recent morphological changes of the Changjiang (Yangtze River) mega-delta in the Anthropocene, China: Impact from natural and anthropogenic changes. Holocene 2021, 31, 791-801. [CrossRef]

97. Hao, X.; Ouyang, X.; Zheng, L.; Zhuo, B.; Liu, Y. Palynological evidence for early to mid-Holocene sea-level fluctuations over the present-day Ningshao Coastal Plain in Eastern China. Mar. Geol. 2020, 426, 106213. [CrossRef]

98. Wang, Z.; Ryves, D.B.; Lei, S.; Nian, X.; Lv, Y.; Tang, L.; Wang, L.; Wang, J.; Chen, J. Middle Holocene marine flooding and human response in the south Yangtze coastal plain, East China. Quat. Sci. Rev. 2018, 187, 80-93. [CrossRef]

99. Tang, L.; Shu, J.; Chen, J.; Wang, Z. Mid- to late Holocene vegetation change recorded at a Neolithic site in the Yangtze coastal plain, East China. Quat. Int. 2019, 519, 122-130. [CrossRef]

100. Huang, J.; Li, Y.; Ding, F.; Zheng, T.; Meadows, M.E.; Wang, Z. Sedimentary records of mid-Holocene coastal flooding at a Neolithic site on the southeast plain of Hangzhou Bay, east China. Mar. Geol. 2021, 431, 106380. [CrossRef]

101. Zhao, B.; Wang, Z.; Chen, Z.; Wu, G. Climate, vegetation and geomorphology evolution since 8 ka BP recorded by sediments from dish-like depression of Taihu Lake plain. J. Palaeogeogr. 2007, 9, 321-330.

102. Liu, C.; Walker, H.J. Sedimentary characteristics of cheniers and the formation of the chenier plains of East China. J. Coast. Res. 1989, 5, 353-368.

103. Yan, Q.; Xu, S.; Shao, X. Holocene cheniers in the Yangtze delta, China. Mar. Geol. 1989, 90, 337-343. [CrossRef]

104. Zhao, X. Cheniers in China, an overview. Mar. Geol. 1989, 90, 311-320. [CrossRef]

105. Chen, J.; Liu, C.; Zhang, C.; Walker, H.J. Geomorphological development and sedimentation in Qiantang estuary and Hangzhou Bay. J. Coast. Res. 1990, 6, 559-572.

106. Walker, D. Direction and rate in some British post-glacial hydroseres. In Studies in the Vegetational History of the British Isles; Walker, D., West, R.G., Eds.; Cambridge University Press: Cambridge, UK, 1970; pp. 117-139.

107. Rodwell, J.S. British Plant Communities Volume 5. Aquatic Communities, Swamps and Tall-Herb Fens; Cambridge University Press: Cambridge, UK, 1995.

108. Shen, J. Spatiotemporal variations of Chinese lakes and their driving mechanisms since the Last Glacial Maximum: A review and synthesis of lacustrine sediment archives. Chin. Sci. Bull. 2013, 58, 17-31. [CrossRef]

109. Xu, Y.; Lai, Z.; Li, C. Sea-level change as the driver for lake formation in the Yangtze plain-A review. Glob. Planet. Chang. 2019, 181, 102980. [CrossRef]

110. Zhang, F.; Xue, B.; Yao, S. The lake status records and palaeoclimatic changes of China since the last Interstadial. Quat. Int. 2019, 527, 12-18. [CrossRef]

111. Ran, M.; Chen, L. The 4.2 ka BP climatic event and its cultural responses. Quat. Int. 2019, 521, 158-167. [CrossRef]

112. Yang, H.; Xie, Z.; Yang, D. Formation and evolution of the Taihu lake and the Holocene sea level. In Collection of the Quaternary Glaciation and Quaternary Geology; Yang, H.R., Ed.; Publishing House of Geology: Beijing, China, 1987; pp. 49-84. (In Chinese)

113. Chang, W.; Xu, X.; Yang, J.; Liu, J. Evolution in Taihu Lake ecosystem as evidence of changes in sediment profiles. J. Lake Sci. 1994, 6, 217-226. [CrossRef]

114. Chen, Z.; Hong, X.; Li, S.; Wang, L.; Shi, X. Study of archaeology-related environment evolution of Taihu Lake in southern Changjiang Delta Plain. Acta Geogr. Sin. 1997, 52, 131-137.

115. Yang, X.; Zhu, Y.; Jiang, X.; Wu, Y.; Wang, S. Environmental changes from spore-pollen record of Mianyang region over the past 10000 years. J. Lake Sci. 1998, 10, 23-29. (In Chinese)

116. Qu, W.; Xue, B.; Dickman, M.D.; Wang, S.; Fan, C.; Wu, R.; Zhang, P.; Chen, J.; Wu, Y. A 14000 year record of palaeoenvironmental change in the western basin of China's third largest lake, Lake Taihu. Hydrobiologia 2000, 432, 113-120. [CrossRef]

117. Yu, S.; Zhu, C.; Song, H.; Qu, W. Role of climate in the rise and fall of Neolithic cultures on the Yangtze Delta. Boreas 2000, 29, 157-165. [CrossRef]

118. Wang, J.; Chen, X.; Zhu, X.; Liu, J.; Chang, W. Taihu Lake, lower Yangtze drainage basin: Evolution, sedimentation rate and the sea level. Geomorphology 2001, 41, 183-193. [CrossRef]

119. Wu, L.; Zhu, C.; Ma, C.; Li, F.; Meng, H.; Liu, H.; Li, L.; Wang, X.; Sun, W.; Song, Y. Mid-Holocene palaeoflood events recorded at the Zhongqiao Neolithic cultural site in the Jianghan Plain, middle Yangtze River Valley, China. Quat. Sci. Rev. 2017, 173, 145-160. [CrossRef]

120. Kajita, H.; Kawahata, H.; Wang, K.; Zheng, H.; Yang, S.; Ohkouchi, N.; Utsunomiya, M.; Zhou, B.; Zheng, B. Extraordinary cold episodes during the mid-Holocene in the Yangtze delta: Interruption of the earliest rice cultivating civilization. Quat. Sci. Rev. 2018, 201, 418-428. [CrossRef]

121. Baker, V.R. Palaeoflood hydrology and extraordinary flood events. J. Hydrol. 1987, 96, 79-99. [CrossRef]

122. Tian, R.; Cao, C.; Peng, L.; Ma, G.; Bao, D.; Guo, J.; Yomwan, P. The use of HJ-1A/B satellite data to detect changes in the size of wetlands in response to a sudden turn from drought to flood in the middle and lower reaches of the Yangtze River system in China. Geomat. Nat. Haz. Risk 2016, 7, 287-307. [CrossRef]

123. Acreman, M.; Holden, J. How wetlands affect floods. Wetlands 2013, 33, 773-786. [CrossRef]

124. Zheng, S.; Feng, L. Historical evidence on climatic instability above normal in cool periods in China. Sci. China Ser. B 1986, 29, $441-448$. 
125. Chen, J. An approach to the data processing of historical climate materials on the basis of floods and droughts of Taihu Basin. Acta Geogr. Sin. 1987, 42, 231-242. (In Chinese)

126. Zhang, J.; Crowley, T.J. Historic climate records in China and reconstruction of past climate. J. Clim. 1989, 2, 833-849. [CrossRef]

127. Zheng, J.; Wang, W.; Ge, Q.; Man, Z.; Zhang, P. Precipitation variability and extreme events in eastern China during the past 1500 years. Terr. Atmos. Ocean. Sci. 2006, 17, 579-592. [CrossRef]

128. Zhang, Q.; Chen, J.; Becker, S. Flood/drought change of last millennium in the Yangtze Delta and its possible connections with Tibetan climatic changes. Glob. Planet. Chang. 2007, 57, 213-221. [CrossRef]

129. Zhang, Q.; Gemmer, M.; Chen, J. Climate changes and flood/drought risk in the Yangtze Delta, China during the past millennium. Quat. Int. 2008, 176-177, 62-69. [CrossRef]

130. Zhang, Q.; Chen, Y.; Chen, J. Flood/drought variability in the Yangtze Delta and association with the climatic changes from the Guliya ice core: A wavelet approach. Quat. Int. 2008, 189, 163-172. [CrossRef]

131. Yin, J.; Su, Y.; Fang, X. Climate change and social vicissitudes in China over the past two millennia. Quat. Res. 2016, 86, 133-143. [CrossRef]

132. Li, T.; Li, J.; Zhang, D.D. Yellow River flooding during the past two millennia from historical documents. Prog. Phys. Geogr. 2020, 44, 661-678. [CrossRef]

133. Hao, Z.; Wu, M.; Zheng, J.; Chen, J.; Zhang, X.; Luo, S. Patterns in data of extreme droughts/floods and harvests grades derived from historical documents in eastern China during 801-1910. Clim. Past 2020, 16, 101-116. [CrossRef]

134. Wan, Z.; Gao, Z.; Chen, X.; Zhang, Z.; Liao, F.; Liu, G.; Jia, Y.; Jiang, M. Water level reconstruction and characteristic diagnosis of China's largest freshwater lake for the past 500 years. Quat. Int. 2020, 558, 66-74. [CrossRef]

135. Wu, L.; Wang, X.; Zhu, C.; Zhang, G.; Li, F.; Li, L.; Li, S. Ancient culture decline after the Han Dynasty in the Chaohu Lake basin, East China: A geoarchaeological perspective. Quat. Int. 2012, 275, 23-29. [CrossRef]

136. Wu, L.; Li, F.; Zhu, C.; Li, L.; Li, B. Holocene environmental change and archaeology, Yangtze River Valley, China: Review and prospects. Geosci. Front. 2012, 3, 875-892. [CrossRef]

137. Yi, C.; Liu, H.; Rose, N.L.; Yang, H.; Ni, L.; Xie, P. Sediment sources and the flood record from Wanghu lake, in the middle reaches of the Yangtze River. J. Hydrol. 2006, 329, 568-576. [CrossRef]

138. Wang, M.; Zheng, H.; Xie, X.; Fan, D.; Yang, S.; Zhao, Q.; Wang, K. A 600-year flood history in the Yangtze River drainage: Comparison between a subaqueous delta and historical records. Chin. Sci. Bull. 2011, 56, 188-195. [CrossRef]

139. Zhu, C.; Yu, S.; Shi, W. Holocene deposits and paleo-floods on the north bank of the Yangtze River, Nanjing area. Geogr. Res. 1997, 16, 23-30. (In Chinese)

140. Xie, Y.; Wang, W.; Wang, P. Characteristics of grain size for palaeoflood slackwater deposits. Hydrology 2000, 20, 18-20.

141. Yu, S.; Zhu, C.; Wang, F. Radiocarbon constraints on the Holocene flood deposits of the Ning-Zhen mountains, lower Yangtze River area of China. J. Quat. Sci. 2003, 18, 521-525. [CrossRef]

142. Li, L.; Zhu, C.; Jiang, F.; Zhao, Q.; Lin, L. Research on the disappearance causes of the Tenghualuo Site in Lianyungang, Jiangsu Province, China. Chin. Sci. Bull. 2008, 53, 161-176. [CrossRef]

143. Wu, L.; Wang, X.; Zhou, K.; Mo, D.; Zhu, C.; Gao, C.; Zhang, G.; Li, L.; Han, W. Transmutation of ancient settlements and environmental changes between 6000 and 2000 a BP in the Chaohu Lake Basin, East China. J. Geogr. Sci. 2010, 20, 687-700. [CrossRef]

144. Luo, C.; Zheng, Z.; Zou, H.; Pan, A.; Fang, G.; Bai, J.; Li, J.; Yang, M. Palaeoenvironmental significance of grain-size distribution of river flood deposits: A study of the archaeological sites of the Apengiiang River Drainage, upper Yangtze region, Chongqing, China. J. Archaeol. Sci. 2013, 40, 827-840. [CrossRef]

145. Jia, T.; Ma, C.; Zhu, C.; Guo, T.; Xu, J.; Guan, H.; Zeng, M.; Huang, M.; Zhang, Q. Depositional evidence of palaeofloods during 4.0-3.6 ka BP at the Jinsha site, Chengdu Plain, China. Quat. Int. 2017, 440, 78-89. [CrossRef]

146. Liu, X.; Kettner, A.J.; Cheng, J.; Dai, S. Sediment characteristics of the Yangtze River during major flooding. J. Hydrol. 2020, 590, 125417. [CrossRef]

147. Yi, C.; Appleby, P.G.; Boyle, J.F.; Rose, N.L.; Dai, X.; Xie, P. The sedimentary record of a significant flooding event in Lake Taihu on the Yangtze Delta, China. J. Coast. Res. 2004, 43, 89-100.

148. Zhu, C.; Zheng, C.; Ma, C.; Sun, Z.; Zhu, G.; Wang, H.; Gao, H.; Wang, P.; Huang, R. Identifying palaeoflood deposits archived in Zhongba Site, the Three Gorges reservoir region of the Yangtze River, China. Chin. Sci. Bull. 2005, 50, 2493-2504. [CrossRef]

149. Jin, Y.; Mo, D.; Li, Y.; Ding, P.; Zong, Y.; Zhuang, Y. Ecology and hydrology of early rice farming: Geoarchaeological and palaeo-ecological evidence from the Late Holocene paddy field site at Maoshan, the lower Yangtze. Archaeol. Anthropol. Sci. 2019, 11, 1851-1863. [CrossRef]

150. Yang, D.; Xie, Y. Palaeoflood slack water deposits. Acta Sedimentol. Sin. 1997, 15, 29-32. (In Chinese)

151. Huang, C.; Pang, J.; Zha, X.; Zhou, Y.; Yin, S.; Su, H.; Zhou, L.; Yang, J. Extraordinary hydro-climatic events during the period AD 200-300 recorded by slackwater deposits in the upper Hanjiang River valley, China. Palaeogeogr. Palaeoclimatol. Palaeoecol. 2013, 374, 274-283. [CrossRef]

152. Zhang, Y.; Huang, C.; Pang, J.; Zha, X.; Zhou, Y.; Zhou, Z.; Wang, J.; Gu, H. Sedimentary studies of the Holocene flood slackwater deposits in the lower reaches of the Jinghe River. Chin. J. Soil Sci. 2012, 43, 522-528, (In Chinese with English abstract).

153. Zhang, Y.; Huang, C.; Pang, J.; Zha, X.; Zhou, Y.; Gu, H. Holocene paleofloods related to climatic events in the upper reaches of the Hanjiang River valley, middle Yangtze River basin, China. Geomorphology 2013, 195, 1-12. [CrossRef] 
154. Zhuang, Y.; Ding, P.; French, C. Water management and agricultural intensification of rice farming at the late-Neolithic site of Maoshan, Lower Yangtze River, China. Holocene 2014, 24, 531-545. [CrossRef]

155. Liu, T.; Huang, C.; Pang, J.; Zha, X.; Zhou, Y.; Zhang, Y.; Ji, L. Late Pleistocene and Holocene palaeoflood events recorded by slackwater deposits in the upper Hanjiang River valley, China. J. Hydrol. 2015, 529, 499-510. [CrossRef]

156. Liu, X.; Min, F.; Kettner, A.J. The impact of large to extreme flood events on floodplain evolution of the middle and lower reaches of the Yangtze River, China. Catena 2019, 176, 394-409. [CrossRef]

157. Zha, X.; Huang, C.; Pang, J. Palaeofloods recorded by slackwater deposits on the Qishuihe River in the Middle Yellow River. J. Geogr. Sci. 2009, 19, 681-690. [CrossRef]

158. Zha, X.; Huang, C.; Pang, J.; Zhou, Y. Reconstructing the extraordinary palaeoflood events during $3200-2800$ a BP in the upper reaches of Hanjiang River Valley, China. J. Geogr. Sci. 2014, 24, 446-456. [CrossRef]

159. Zha, X.; Huang, C.; Pang, J.; Liu, J.; Xue, X. Reconstructing the palaeoflood events from slackwater deposits in the upper reaches of Hanjiang River, China. Quat. Int. 2015, 380-381, 358-367. [CrossRef]

160. Guo, Y.; Huang, C.; Zhou, Y.; Pang, J.; Zha, X.; Zhou, L.; Mao, P. Extraordinary flood events and the response to monsoonal climatic change during the last 3000 years along the middle Yangtze River valley, China. Palaeogeogr. Palaeoclimatol. Palaeoecol. 2016, 462, 70-84. [CrossRef]

161. Wang, Y.; Cheng, H.; Edwards, R.L.; He, Y.; Kong, X.; An, Z.; Wu, J.; Kelly, M.G.; Dykoski, C.A.; Li, X. The Holocene Asian monsoon: Links to solar changes and North Atlantic climate. Science 2005, 308, 854-857. [CrossRef] [PubMed]

162. Blender, R.; Zhu, X.; Zhang, D.; Fraedrich, K. Yangtze runoff, precipitation, and the east Asian monsoon in a 2800 years climate control simulation. Quat. Int. 2011, 244, 194-201. [CrossRef]

163. Milliman, J.D.; Shen, H.; Yang, Z.; Mead, R.H. Transport and deposition of river sediment in the Changjiang estuary and adjacent continental shelf. Contin. Shelf Res. 1985, 4, 37-45. [CrossRef]

164. Xu, G.; Liu, J.; Gugliotta, M.; Saito, Y.; Chen, L.; Zhang, X.; Hu, G. Link between East Asian summer monsoon and sedimentation in river-mouth sandbars since the early Holocene preserved in the Yangtze River subaqueous delta front. Quat. Res. 2020, 95, 84-96. [CrossRef]

165. Kanhaiya, S.; Singh, B.P.; Tripathi, M.; Sahu, S.; Tiwari, V. Lithofacies and particle-size characteristics of late Quaternary floodplain deposits along the middle reaches of the Ganga river, central Ganga plain, India. Geomorphology 2017, 284, 220-228. [CrossRef]

166. Guo, Y.; Huang, C.; Pang, J.; Zha, X.; Zhou, Y.; Wang, L.; Zhang, Y.; Hu, G. Investigating extreme flood response to Holocene palaeoclimate in the Chinese monsoonal zone: A palaeoflood case study from the Hanjiang River. Geomorphology 2015, 238, 187-197. [CrossRef]

167. Yu, L.; Xu, Y.; Xu, S. Paleoenvironmental impaction on magnetic measurements on sediment cores from Taihu lake, east China. J. Lake Sci. 1995, 7, 141-150.

168. Li, Y.; Guo, Y.; Yu, G. An analysis of extreme flood events during the past 400 years at Taihu Lake, China. J. Hydrol. 2013, 500, 217-225. [CrossRef]

169. Chen, Z.; Wang, Z.; Schneiderman, J.; Tao, J.; Cai, Y. Holocene climate fluctuations in the Yangtze Delta of eastern China and the Neolithic response. Holocene 2005, 15, 915-924. [CrossRef]

170. Huang, M.; Zhu, C.; Ma, C.; Yang, Z.; Liu, Y.; Jia, T. The Hongqiaocun Site: The earliest evidence of ancient flood sedimentation of the water conservancy facilities in the Chengdu Plain, China. Catena 2020, 185, 104296. [CrossRef]

171. Zhu, C.; Yu, S.; Lu, C. The study of Holocene environmental archaeology and extreme flood disaster in the Three Gorges of the Changjiang River and the Jianghan Plain. Acta Geogr. Sin. 1997, 52, 268-278, (In Chinese with English abstract).

172. Zhu, C.; Yu, S.; Zhang, Q.; Zhang, Y.; Li, G.; Zhao, N. Neolithic cultural interruptions and Holocene buried palaeo-trees in the Yangtze Delta. J. Nanjing Univ. Nat. Sci. 2000, 36, 693-701.

173. Zhang, Q.; Jiang, T.; Shi, Y.; King, L.; Liu, C.; Metzler, M. Palaeo-environmental changes in the Yangtze Delta during past 8000 years. J. Geogr. Sci. 2004, 14, 105-112. [CrossRef]

174. Zhang, Q.; Zhu, C.; Liu, C.; Jiang, T. Environmental change and its impacts on human settlement in the Yangtze Delta, P.R. China. Catena 2005, 60, 267-277. [CrossRef]

175. Xu, Q.; Yang, X.; Wu, C.; Meng, L.; Wang, Z. Alluvial pollen on the north China plain. Quat. Res. 1996, 46, $270-280$.

176. Song, B.; Li, Z.; Lu, H.; Mao, L.; Saito, Y.; Yi, S.; Lim, J.; Li, Z.; Lu, A.; Sha, L.; et al. Pollen record of the centennial climate changes during 9-7 cal ka BP in the Changjiang (Yangtze) River Delta plain, China. Quat. Res. 2017, 87, 275-287. [CrossRef]

177. Dai, L.; Weng, C.; Lu, J.; Mao, L. Pollen quantitative distribution in marine and fluvial surface sediments from the northern South China Sea: New insights into pollen transportation and deposition mechanisms. Quat. Int. 2014, 325, 136-149. [CrossRef]

178. Liu, Y.; Sun, Q.; Fan, D.; Lai, X.; Xu, L.; Finlayson, B.; Chen, Z. Pollen evidence to interpret the history of rice farming at the Hemudu site on the Ningshao coast, eastern China. Quat. Int. 2016, 426, 195-203. [CrossRef]

179. Sun, X.; Wu, Y. The distribution of pollen and algae in surface sediments of Dianchi, Yunnan Province, China. Rev. Palaeobot. Palynol. 1988, 55, 193-206. [CrossRef]

180. van Geel, B. Non-pollen palynomorphs. In Tracking Environmental Change Using Lake Sediments, Terrestrial, Algal and Siliceous Indicators, Vol. 3; Smol, J.P., Birks, H.J.B., Last, W.M., Eds.; Kluwer: Dordrecht, The Netherlands, 2001; Volume 3, pp. $99-119$.

181. Tang, L.; Mao, L.; Lu, X.; Ma, Q.; Zhou, Z.; Yang, C.; Kong, Z.; Batten, D.J. Palaeoecological and palaeoenvironmental significance of some important spores and micro-algae in Quaternary deposits. Chin. Sci. Bull. 2013, 58, 3125-3139. [CrossRef] 
182. Yang, Y.; Yin, X.; Yang, Z.; Sun, T.; Xu, C. Detection of regime shifts in a shallow lake ecosystem based on multi-proxy paleolimnological indicators. Ecol. Indic. 2018, 92, 312-321. [CrossRef]

183. Hu, H.; Wei, Y. The Freshwater Algae of China: Systematic, Taxonomy and Ecology; Science Press: Beijing, China, 2006. (In Chinese)

184. Jankovská, V.; Komárek, J. Indicative value of Pediastrum and other coccal green algae in palaeoecology. Folia Geobot. 2000, 35, 59-73, 75-82. [CrossRef]

185. Kramer, A.; Herzschuh, U.; Mischke, S.; Zhang, C. Late Quaternary environmental history of the south-eastern Tibetan Plateau inferred from the Lake Naleng non-pollen palynomorph record. Veget. Hist. Archaeobot. 2010, 19, 453-468. [CrossRef]

186. Wang, K.; Zhang, Y.; Sun, Y. The spore-pollen and algae assemblages from the surface layer sediments of the Yangtze River delta. Acta Geogr. Sin. 1982, 37, 261-271, (In Chinese with English abstract).

187. Mao, L.; Wang, W.; Shu, J.; Yang, X. Holocene spores and microscopic algae from the Yangtze Delta, East China. Acta Palaeontol. Sin. 2011, 50, 154-165. (In Chinese)

188. Liu, R.; Qin, J.; Mei, X. Sedimentary environment changes of the Ningshao Plain since the later stages of the Late Pleistocene: Evidence from palynology and stable organic carbon isotopes. Quat. Int. 2014, 333, 188-197. [CrossRef]

189. Ouyang, X.; Hao, X.; Zheng, L.; Zhuo, B.; Liu, Y. Early to mid-Holocene vegetation history, regional climate variability and human activity of the Ningshao Coastal Plain, eastern China: New evidence from pollen, freshwater algae and dinoflagellate cysts. Quat. Int. 2019, 528, 88-99. [CrossRef]

190. Nielsen, H.; Sørensen, J. Taxonomy and stratigraphy of Late-Glacial Pediastrum taxa from Lysmosen, Denmark-A preliminary study. Rev. Palaeobot. Palynol. 1992, 74, 55-75. [CrossRef]

191. Batten, D.J.; Grenfell, H.R. Botryococcus. In Palynology and Stratigraphy; Jansonius, J., McGregor, D.C., Eds.; American Association of Stratigraphic Palynologists Foundation: New York, NY, USA, 1996; Volume 1, pp. 205-214.

192. Jiang, W.; Guo, Z.; Sun, X.; Wu, H.; Chu, G.; Yuan, B.; Hatté, C.; Guiot, J. Reconstruction of climate and vegetation changes of Lake Bayanchagan, (Inner Mongolia): Holocene variability of the East Asian monsoon. Quat. Res. 2006, 65, 411-420. [CrossRef]

193. Whitney, B.S.; Mayle, F.E. Pediastrum species as potential indicators of lake-level change in tropical South America. J. Paleolimnol. 2012, 47, 601-615. [CrossRef]

194. Xiang, L.; Huang, X.; Huang, C.; Chen, X.; Wang, H.; Chen, J.; Hu, Y.; Sun, M.; Xiao, Y. Pediastrum (Chlorophyceae) assemblages in surface lake sediments in China and western Mongolia and their environmental significance. Rev. Palaeobot. Palynol. 2021. [CrossRef]

195. Xiao, X.; Yao, A.; Hillman, A.; Shen, J.; Haberle, S.G. Vegetation, climate and human impact since 20 ka in central Yunnan Province based on high-resolution pollen and charcoal records from Dianchi, southwestern China. Quat. Sci. Rev. 2020, $236,106297$. [CrossRef]

196. Chen, X.; Huang, X.; Tang, L.; Chen, F. A preliminary investigation of relationship between modern Pediastrum and the level of Xingyun Lake, central Yunnan, and its implications for the interpretation of the fossil record. Chin. Sci. Bull. 2016, 61, 2395-2408. [CrossRef]

197. van Geel, B.; Coope, G.R.; van der Hammen, T. Palaeoecology and stratigraphy of the Late-glacial type section at Usselo (The Netherlands). Rev. Palaeobot. Palynol. 1989, 60, 25-129. [CrossRef]

198. van Geel, B.; Grenfell, H.R. Green and blue-green algae 7A. spores of Zygnemataceae. In Palynology: Principles and Applications; Jansonius, J., McGregor, D.C., Eds.; American Association of Stratigraphic Palynologists Foundation: College Station, TX, USA, 1996; Volume 1, pp. 173-179.

199. van Geel, B. Fossil spores of Zygnemataceae in ditches of a prehistoric settlement in Hoogkarspel (The Netherlands). Rev. Palaeobot. Palynol. 1976, 22, 327-344. [CrossRef]

200. Medianic, S. Freshwater algal palynomorph records from Holocene deposits in the coastal plain of Rio Grande do Sul, Brazil. Rev. Palaeobot. Palynol. 2006, 141, 83-101. [CrossRef]

201. Chmura, G.L.; Stone, P.A.; Ross, M.S. Non-pollen microfossils in Everglades sediments. Rev. Palaeobot. Palynol. 2006, 141, 103-119. [CrossRef]

202. Hillbrand, M.; van Geel, B.; Hasenfratz, A.; Hadorn, P.; Haas, J.N. Non-pollen palynomorphs show human-and livestock-induced eutrophication of Lake Nussbaumersee (Thurgau, Switzerland) since Neolithic times (3840 BC). Holocene 2014, 24, 559-568. [CrossRef]

203. Joannin, S.; Vannière, B.; Gallop, D.; Peyron, O.; Haas, J.N.; Gilli, A.; Chapron, R.; Wirth, S.B.; Anselmetti, F.; Desmet, M.; et al. Climate and vegetation changes during the Lateglacial and early-middle Holocene at Lake Ledro (southern Alps, Italy). Clim. Past 2013, 9, 913-933. [CrossRef]

204. Miola, A.; Bondesan, A.; Corain, L.; Favaretto, S.; Mozzi, P.; Piovan, S.; Sostizzo, I. Wetlands in the Venetian Po plain (northeastern Italy) during the Last Glacial Maximum: Interplay between vegetation, hydrology and sedimentary environment. Rev. Palaeobot. Palynol. 2006, 141, 53-81. [CrossRef]

205. Revelles, J.; van Geel, B. Human impact and ecological changes in lakeshore environments. The contribution of non-pollen palynomorphs in Lake Banyoles (NE Iberia). Rev. Palaeobot. Palynol. 2016, 232, 81-97. [CrossRef]

206. Sarmaja-Korjonen, K.; Seppanen, A.; Bennike, O. Pediastrum algae from the classic late glacial Bølling So site, Denmark: Response of aquatic biota to climate change. Rev. Palaeobot. Palynol. 2006, 138, 95-107. [CrossRef]

207. An, Z.; Wu, G.; Li, J.; Sun, Y.; Liu, Y.; Zhou, W.; Cai, Y.; Duan, A.; Li, L.; Mao, J.; et al. Global monsoon dynamics and climate change. Ann. Rev. Earth Planet. Sci. 2015, 43, $29-77$. 
208. Chen, Z.; Li, J.; Shen, H.; Wang, Z. Yangtze River of China: Historical analysis of discharge variability and sediment flux. Geomorphology 2001, 41, 77-91. [CrossRef]

209. Chen, Z.; Zhao, Y. Impact on the Yangtze (Changjiang) estuary from its drainage basin: Sediment load and discharge. Chin. Sci. Bull. 2001, 46, 73-80. [CrossRef]

210. Hori, K.; Saito, Y.; Zhao, Q.; Wang, P. Architecture and evolution of the tide-dominated Changiiang (Yangtze) River delta, China. Sedim. Geol. 2002, 146, 249-264. [CrossRef]

211. Huang, H.; Tang, B.; Yang, W. Sedimentology of Yangtze Delta; Geology Press: Beijing, China, 1999.

212. Zhao, Y.; Zou, X.; Gao, J.; Wang, C. Recent sedimentary record of storms and floods within the estuarine-inner shelf region of the East China Sea. Holocene 2017, 27, 439-449. [CrossRef]

213. Zhang, S.; Tao, S.; Zhang, Q.; Wei, J. Large and meso- $\alpha$ scale characteristics of intense rainfall in the mid- and lower reaches of the Yangtze river. Chin. Sci. Bull. 2002, 47, 779-786. [CrossRef]

214. Huang, R.; Chen, L.; Wang, L.; Lin, Z. Characteristics, processes and causes of the spatiotemporal variabilities of the East Asian monsoon system. Adv. Atmos. Sci. 2012, 29, 910-942. [CrossRef]

215. Zhang, R. Changes in east Asian summer monsoon and summer rainfall over eastern China during recent decades. Sci. Bull. 2015, 60, 1222-1224. [CrossRef]

216. An, Z. The history and variability of the east Asian paleomonsoon climate. Quat. Sci. Rev. 2000, 19, 171-187. [CrossRef]

217. Wang, P.; Clemens, S.; Beaufort, L.; Braconnot, P.; Ganssen, G.; Jian, Z.; Kershaw, P.; Sarnthein, M. Evolution and variability of the Asian monsoon system: State of the art and outstanding issues. Quat. Sci. Rev. 2005, 24, 595-629. [CrossRef]

218. Zhao, G.; Mu, X.; Hörmann, G.; Fohrer, N.; Xiong, M.; Su, B.; Li, X. Spatial patterns and temporal variability of dryness/wetness in the Yangtze River Basin, China. Quat. Int. 2012, 282, 5-13. [CrossRef]

219. Wang, L.; Gu, W. The Eastern China flood of June 2015 and its causes. Sci. Bull. 2016, 61, 178-184. [CrossRef]

220. Dai, S.; Lu, X. Sediment deposition and erosion during the extreme flood events in the middle and lower reaches of the Yangtze River. Quat. Int. 2010, 226, 4-11. [CrossRef]

221. Lu, F.; Ma, C.; Zhu, C.; Lu, H.; Zhang, X.; Huang, K.; Guo, T.; Li, K.; Li, L.; Li, B.; et al. Variability of East Asian summer monsoon precipitation during the Holocene and possible forcing mechanisms. Clim. Dyn. 2019, 52, 969-989. [CrossRef]

222. Kundzewicz, Z.W.; Jiang, T.; Su, B. Floods in the Yangtze River Basin, China. In Natural Disasters and Adaptation to Climate Change; Boulter, S., Palutikof, J., Karoly, D.J., Guitart, D., Eds.; Cambridge University Press: Cambridge, UK, 2013; pp. $190-196$.

223. Wang, B.; Wu, R.; Fu, X. Pacific-East Asian teleconnection: How does ENSO affect East Asian climate. J. Clim. 2000, 13, 1517-1536. [CrossRef]

224. Huang, R.; Chen, W.; Yang, B.; Zhang, R. Recent advances in studies of the interaction between the East Asian Winter and Summer Monsoons and ENSO cycle. Adv. Atmos. Sci. 2004, 21, 407-424.

225. Shi, W.; Zhu, C. Correlation analysis of flood evolution with environmental changes in Taihu Lake region. J. Nat. Dis. Sci. 2004, $13,32-37$.

226. Jiang, T.; Zhang, Q.; Wang, S. The relationship between droughts, floods and climatic changes in the middle and lower reaches of the Changjiang River since last 1000 years. Quat. Sci. 2004, 24, 518-524, (In Chinese, with English abstract).

227. Jiang, T.; Zhang, Q.; Zhu, D.; Wu, Y. Yangtze floods and droughts (China) and teleconnections with ENSO activities (1470-2003). Quat. Int. 2006, 144, 29-37.

228. Dykoski, C.A.; Edwards, R.L.; Cheng, H.; Yuan, D.; Cai, Y.; Zhang, M.; Lin, Y.; Qing, J.; An, Z.; Revenaugh, J. A high-resolution, absolute-dated Holocene and deglacial Asian monsoon record from Dongge Cave, China. Earth Planet. Sci. Lett. 2005, 233, 71-86. [CrossRef]

229. Li, W.; Zhai, P.; Cai, J. Research on the Relationship of ENSO and the frequency of extreme precipitation events in China. Adv. Clim. Chang. Res. 2011, 2, 101-107. [CrossRef]

230. Lim, J.; Fujiki, T. Vegetation and climate variability in East Asia driven by low-latitude oceanic forcing during the middle to late Holocene. Quat. Sci. Rev. 2011, 30, 2487-2497. [CrossRef]

231. Xiao, M.; Zhang, Q.; Singh, V.P. Influences of ENSO, NAO, IOD and PDO on seasonal precipitation regimes in the Yangtze River basin, China. Int. J. Climatol. 2015, 35, 3556-3567. [CrossRef]

232. Zhang, Q.; Xu, C.; Jiang, T.; Wu, Y. Possible influence of ENSO on annual maximum streamflow of the Yangtze River, China. J. Hydrol. 2007, 333, 265-274. [CrossRef]

233. Yao, F.; Ma, C.; Zhu, C. Holocene climate change in the western part of the Taihu Lake region, east China. Palaeogeogr. Palaeoclimatol. Palaeoecol. 2017, 485, 963-973. [CrossRef]

234. Li, C.; Li, Y.; Zheng, Y.; Yu, S.; Tang, L.; Li, B.; Cui, Q. A high-resolution pollen record from East China reveals large climate variability near the Northgrippian-Meghalayan boundary (around 4200 years ago) exerted societal influence. Palaeogeogr. Palaeoclimatol. Palaeoecol. 2018, 512, 156-165. [CrossRef]

235. Moy, C.M.; Seltzer, G.O.; Rodbell, D.T.; Anderson, D.M. Variability of El Niño/ Southern Oscillation activity at millennial timescales during the Holocene epoch. Nature 2002, 420, 162-165. [CrossRef] [PubMed]

236. Wu, R.; Hu, Z.; Kirtman, B.P. Evolution of ENSO-related rainfall anomalies in East Asia. J. Clim. 2003, 16, 3742-3758. [CrossRef]

237. Zhang, W.; Jin, F.; Stuecker, M.F.; Wittenberg, A.T.; Timmermann, A.; Ren, H.; Kug, J.S.; Cai, W.; Cane, M. Unraveling El Nino's impact on the East Asian Monsoon and Yangtze River summer flooding. Geophys. Res. Lett. 2016, 43, 11375-11382. [CrossRef] 
238. Yancheva, G.; Nowaczyk, N.R.; Mingram, J.; Dulski, P.; Schettler, G.; Negendank, J.; Liu, J.; Sigman, D.M.; Peterson, L.C.; Haug, G.H. Influence of the intertropical convergence zone on the East Asian Monsoon. Nature 2007, 445, 74-77. [CrossRef]

239. Shao, X.; Wang, Y.; Cheng, H.; Kong, X.; Wu, J.; Edwards, R.L. Long-term trend and abrupt events of the Holocene Asian monsoon inferred from a stalagmite $\delta^{18} \mathrm{O}$ record from Shennongiia in Central China. Chin. Sci. Bull. 2006, 51, 221-228. [CrossRef]

240. Shi, Y.; Kong, Z.; Wang, S.; Tang, L.; Wang, F.; Yao, T.; Zhao, X.; Zhang, P.; Shi, S. Mid-Holocene climates and environments in China. Glob. Planet. Chang. 1993, 7, 219-233.

241. Morrill, C.; Overpeck, J.; Cole, J.E. A synthesis of abrupt changes in the Asian summer monsoon since the last deglaciation. Holocene 2003, 13, 465-476. [CrossRef]

242. Cosford, J.; Qing, H.; Eglington, B.; Mattey, D.; Yuan, D.; Zhang, M.; Cheng, H. East Asian monsoon variability since the Mid-Holocene recorded in a high-resolution, absolute-dated aragonite speleothem from eastern China. Earth Planet. Sci. Lett. 2008, 275, 296-307. [CrossRef]

243. Dong, J.; Wang, Y.; Cheng, H.; Hardt, B.; Edwards, R.L.; Kong, X.; Wu, J.; Chen, S.; Liu, D.; Jiang, X.; et al. A high-resolution stalagmite record of the Holocene East Asian monsoon from Mt. Shennongjia, central China. Holocene 2010, 20, $257-264$. [CrossRef]

244. Li, J.; Dodson, J.; Yan, H.; Wang, W.; Innes, J.B.; Zong, Y.; Zhang, X.; Xu, Q.; Ni, J.; Lu, F. Quantitative Holocene climatic reconstructions for the lower Yangtze region of China. Clim. Dyn. 2018, 50, 1101-1113. [CrossRef]

245. Tang, L.; Shen, C. The vegetation and climate of Holocene Megathermal in Northern Jiangsu Province. In The Climates and Environments of the Holocene Megathermal in China; Shi, Y., Ed.; China Ocean Press: Beijing, China, 1992; pp. 80-93. (In Chinese)

246. Zhu, C.; Zhang, Q. Climatic evolution in the Yangtze Delta region in the late Holocene epoch. J. Geogr. Sci. 2006, 16, 423-429. [CrossRef]

247. Bai, Y.; Zhang, P.; Gao, T.; Yu, R.; Zhou, P.; Cheng, H. The 5400 a BP weakening event of the Asian summer monsoon and cultural evolution. Sci. China D. Earth Sci. 2017, 60, 1171-1182. [CrossRef]

248. Sha, L.; Li, X.; Tang, J.; Shu, J. Early to mid-Holocene palaeoenvironment change and sedimentary evolution in the Xianghu area, Zhejiang. Int. J. Environ. Res. Public Health 2020, 17, 7099. [CrossRef]

249. Patalano, R.; Wang, Z.; Leng, Q.; Liu, W.; Zheng, Y.; Sun, G.; Yang, H. Hydrological changes facilitated early rice farming in the lower Yangtze River Valley in China: A molecular isotope analysis. Geology 2015, 43, 639-642. [CrossRef]

250. Tao, J.; Chen, M.; Xu, S. A Holocene environmental record from the southern Yangtze River delta, eastern China. Palaeogeogr. Palaeoclimatol. Palaeoecol. 2006, 230, 204-229. [CrossRef]

251. Alley, R.B.; Ágústsdóttir, A.M. The 8k event: Cause and consequences of a major Holocene abrupt climate change. Quat. Sci. Rev. 2005, 24, 1123-1149. [CrossRef]

252. Rohling, E.J.; Pälike, H. Centennial-scale climate cooling with a sudden cold event around 8,200 years ago. Nature 2005, 434, 975-979. [CrossRef] [PubMed]

253. Liu, Y.; Henderson, G.M.; Hu, C.; Mason, A.J.; Charnley, N.; Johnson, K.R.; Xie, S. Links between the East Asian monsoon and North Atlantic climate during the 8,200 year event. Nat. Geosci. 2013, 6, 117-120. [CrossRef]

254. Tian, C.; Liao, W.; Chen, Q.; Yao, Y.; Seong, C.; Bae, C.; Wang, W. Human behavioural responses to the 8.2 ka BP climatic event: Archaeological evidence from the Zhongshandong Cave Site in Bubing basin, Guangxi, southern China. Quat. Int. 2020, 563, 96-104. [CrossRef]

255. Yao, T.; Thompson, L. Trends and features of climatic changes in the past 5000 years recorded by the Dunde ice core. Ann. Glaciol. 1992, 16, 21-24.

256. Perry, C.A.; Hsu, K. Geophysical, archaeological, and historical evidence support a solar-output model for climate change. Proc. Natl. Acad. Sci. USA 2000, 97, 12433-12438. [CrossRef]

257. Mayewski, P.A.; Rohling, E.E.; Stager, J.C.; Karlén, W.; Maasch, K.A.; Meeker, L.D.; Meyerson, E.A.; Gasse, F.; van Kreveld, S.; Holmgren, K.; et al. Holocene climate variability. Quat. Res. 2004, 62, 243-255. [CrossRef]

258. Sun, Q.; Liu, Y.; Wünnemann, B.; Peng, Y.; Jiang, X.; Deng, L.; Chen, J.; Li, M.; Chen, Z. Climate as a factor for Neolithic cultural collapses approximately 4000 years BP in China. Earth-Sci. Rev. 2019, 197, 102915. [CrossRef]

259. Jian, Z.; Li, B.; Pflaumann, U.; Wang, P. Late Holocene cooling event in the western Pacific. Sci. China D 1996, 39, 543-550.

260. Innes, J.B.; Zong, Y.; Wang, Z.; Chen, Z. Climatic and palaeoecological changes during the mid- to late Holocene transition in eastern China: High-resolution pollen and non-pollen palynomorph analysis at Pingwang, Yangtze coastal lowlands. Quat. Sci. Rev. 2014, 99, 164-175. [CrossRef]

261. Walker, M.J.C.; Berkelhammer, M.; Björck, S.; Cwynar, L.C.; Fisher, D.A.; Long, A.J.; Lowe, J.J.; Newnham, R.M.; Rasmussen, S.O.; Weiss, H. Formal subdivision of the Holocene series/epoch: A discussion paper by a working group of INTIMATE (integration of ice-core, marine and terrestrial records) and the subcommission on Quaternary Stratigraphy (international commission on Stratigraphy). J. Quat. Sci. 2012, 27, 649-659. [CrossRef]

262. Wanner, H.; Beer, J.; Bütikofer, J.; Crowly, T.; Cubasch, U.; Flückiger, J.; Goosse, H.; Grosjean, H.; Joos, F.; Kaplan, J.; et al. Mid to late Holocene climate change: A review. Quat. Sci. Rev. 2008, 19-20, 1791-1828. [CrossRef]

263. Sun, J.; Ma, C.; Cao, X.; Zhao, Y.; Deng, Y.; Zhao, L.; Zhu, C. Quantitative precipitation reconstruction in the east-central monsoonal China since the late glacial period. Quat. Int. 2019, 521, 175-184. [CrossRef]

264. Knox, J.C. Sensitivity of modern and Holocene floods to climatic change. Quat. Sci. Rev. 2000, 19, 439-457. [CrossRef] 
265. Wu, W.; Liu, T. Possible role of the "Holocene Event 3" on the collapse of Neolithic Cultures around the Central Plain of China. Quat. Int. 2004, 117, 153-166.

266. An, C.; Tang, L.; Barton, L.; Chen, F. Climate change and cultural response around 4000 cal yr BP in the western part of Chinese Loess Plateau. Quat. Res. 2005, 63, 347-352. [CrossRef]

267. Gao, H.; Zhu, C.; Xu, W. Environmental change and cultural response around 4200 cal. yr BP in the Yishu River Basin, Shandong. J. Geogr. Sci. 2007, 17, 285-292. [CrossRef]

268. Liu, F.; Feng, Z. A dramatic climatic transition at $\sim 4000$ cal. yr BP and its cultural responses in Chinese cultural domains. Holocene 2012, 22, 1181-1197. [CrossRef]

269. Peng, Y.; Sun, Q.; Chen, J.; Li, M. Spatial characteristics of climate around $4.0 \mathrm{ka}$ BP and its impacts on the evolution of prehistoric civilization in China. Geol. Rev. 2013, 59, 248-266. (In Chinese)

270. Lu, T. Mid-Holocene climate and cultural dynamics in eastern Central China. In Climate Change and Cultural Dynamics, A Global Perspective on Mid-Holocene Transition; Anderson, D.G., Maasch, K.A., Sandweiss, D.H., Eds.; Academic Press: London, UK, 2007; pp. 297-329.

271. Liu, L. The Chinese Neolithic_Trajectories to Early States; Cambridge University Press: Cambridge, UK, 2004.

272. Liu, L.; Chen, X. The Archaeology of China: From Late Palaeolithic to the Early Bronze Age; Cambridge University Press: Cambridge, UK, 2012.

273. Liu, Y.; Sun, Q.; Thomas, I.; Zhang, L.; Finlayson, B.; Zhang, W.; Chen, J.; Chen, Z. Middle Holocene coastal environment and the rise of the Liangzhu City complex on the Yangtze delta, China. Quat. Res. 2015, 84, 326-334. [CrossRef]

274. Ling, G.; Ma, C.; Yang, Q.; Hu, Z.; Zheng, H.; Liu, B.; Wang, N.; Chen, M.; Zhao, Y. Landscape evolution in the Liangzhu area since the early Holocene: A comprehensive sedimentological approach. Palaeogeogr. Palaeoclimatol. Palaeoecol. 2021, $562,110141$. [CrossRef]

275. Liu, B.; Wang, N.; Chen, M.; Wu, X.; Mo, D.; Liu, J.; Xu, S.; Zhuang, Y. Earliest hydraulic enterprise in China, 5100 years ago. Proc. Natl. Acad. Sci. USA 2017, 114, 13637-13642. [CrossRef] [PubMed]

276. Fang, J. Lake evolution during the last 3000 years in China and its implications for environmental change. Quat. Res. 1993, 39, 175-185. [CrossRef]

277. Gu, Y.; Liu, H.; Guan, S.; Qin, Y.; Zheng, M.; Yu, J. Possible El-Niño-Southern Oscillation-related lacustrine facies developed in southern Lake Poyang during the late Holocene: Evidence from spore-pollen records. Holocene 2018, 28, 503-512. [CrossRef]

278. Xue, J.; Li, J.; Dang, X.; Meyers, P.A.; Huang, X. Palaeohydrological changes over the last 4000 years in the middle and lower reaches of the Yangtze River: Evidence from particle size and n-alkenes from Longgan Lake. Holocene 2017, 27, 1318-1324. [CrossRef]

279. Sinha, N.; Gandhi, N.; Chakraborty, S.; Krishnan, R.; Yadava, M.G.; Ramesh, R. Abrupt climate change at 2800 yr BP evidenced by a stalagmite record from peninsular India. Holocene 2018, 28, 1720-1730. [CrossRef]

280. van Geel, B.; Buurman, J.; Waterbolk, H.T. Archaeological and palaeoecological indications of an abrupt climate change in The Netherlands, and evidence for climatological teleconnections around 2650 BP. J. Quat. Sci. 1996, 11, 451-460. [CrossRef]

281. Chambers, F.M.; Mauquoy, D.; Brain, S.A.; Blaauw, M.; Daniell, J.R.G. Globally synchronous climate change 2800 years ago: Proxy data from peat in South America. Earth Planet. Sci. Lett. 2007, 253, 439-444. [CrossRef]

282. Wu, Z.; Li, J.; He, J.; Jiang, Z. Occurrence of droughts and floods during the normal Summer Monsoons in the mid- and lower reaches of the Yangtze River. Geophys. Res. Lett. 2006, 33, GL024487. [CrossRef]

283. Hu, S.; Luo, C. Great Floods in Chinese History; China Bookshop Publication: Beijing, China, 1992.

284. Luo, C.; Le, J. China Great Floods—A Review of Disastrous Floods; China Bookstore Press: Beijing, China, 1996.

285. Wu, L.; Zhou, H.; Zhang, S.; Li, L.; Zhang, M.; Ji, C. Spatial-temporal variations of natural disasters during the Ming \& Qing dynasties (1368-1912AD) in Chaohu Lake Basin, East China. Quat. Int. 2018, 467, 242-250.

286. Luo, C.; Zheng, Z.; Zou, H.; Bai, J.; Yuan, D.; Wang, H.; Pan, A.; Li, C.; Li, J.; Cao, L. A palaeoenvironmental study of the Shiniusi archaeological sites in the Wujiang Drainage Area, upper Yangtze River, Chongqing region, China. Quat. Int. 2012, 281 , 66-77. [CrossRef]

287. Yang, B.; Braeuning, A.; Johnson, K.R.; Shi, Y. General characteristics of temperature variation in China during the last two millennia. Geophys. Res. Lett. 2002, 29, 38-1-38-4. [CrossRef]

288. Zhang, X.; Du, Y.; Ma, C.; Ping, S.; Feng, C.; Cui, A. Climatic controls on peat swamp formation and evolution since 1300 year $\mathrm{BP}$ as recorded by phytoliths in the Xishan Mountains, Jiangxi Province, China. Palaeogeogr. Palaeoclimatol. Palaeoecol. 2019, 522, 76-88. [CrossRef]

289. Shi, Y.; Jiang, T.; Su, B.; Chen, J.; Qin, N. Preliminary analysis on the relation between the evolution of heavy floods in the Changjiang River catchment and the climate changes since 1840. J. Lake Sci. 2004, 16, 289-297, (In Chinese with English abstract).

290. Zong, Y.; Cheng, X. The 1998 flood on the Yangtze. Nat. Hazards 2000, 22, 165-184. [CrossRef]

291. Yu, G.; Gui, F.; Li, Y. Simulation of the 1889 extreme flood for Taihu lake, China. J. Lake Sci. 2012, $24,651-657$.

292. Ding, Y.; Wang, Z.; Sun, Y. Inter-decadal variation of the summer precipitation in East China and its association with decreasing Asian summer monsoon. Part I: Observed evidences. Int. J. Climatol. 2008, 28, 1139-1161. [CrossRef]

293. Sun, Y.; Kutzbach, J.; An, Z.; Clemens, S.; Liu, Z.; Liu, W.; Liu, X.; Shi, Z.; Zheng, W.; Liang, L.; et al. Astronomical and glacial forcing of East Asian summer monsoon variability. Quat. Sci. Rev. 2015, 115, 132-142. [CrossRef] 
294. Li, B.; Zhu, C.; Wu, L.; Li, F.; Sun, W.; Wang, X.; Liu, H.; Meng, H.; Wu, D. Relationship between environmental change and human activities in the period of the Shijiahe culture, Tanjialing site, Jianghan Plain, China. Quat. Int. 2013, 308-309, 45-52. [CrossRef]

295. Zhu, C.; Ma, C.; Xu, W.F.; Bai, J.; Zheng, C.; Zhu, G.; Wang, H.; Chen, Y.; Lu, X. Characteristics of paleoflood deposits archived in unit T0403 of Yuxi Site in the Three Gorges reservoir areas, China. Chin. Sci. Bull. 2008, 53, 1-17. [CrossRef]

296. Moore, P.D.; Webb, J.A.; Collinson, M.E. Pollen Analysis; Blackwell Scientific Publications: Oxford, UK, 1991.

297. Clarke, C. Differential recovery of fungal and algal palynomorphs versus embryophyte pollen and spores by three processing techniques. In Aspects of Archaeological Palynology: Methodology and Applications; Davis, O.K., Ed.; Contributions Series 29; American Association of Stratigraphic Palynologists Foundation: Houston, TX, USA, 1994; pp. 53-62.

298. Wang, F.; Chien, Y.; Zhang, Y.; Yang, H. Pollen Flora of China, 2nd ed.; Science Press: Beijing, China, 1995. (In Chinese)

299. Zhang, Y.; Xi, Y.; Zhang, J.; Gao, G.; Du, N.; Sun, X.; Kong, Z. Spore Morphology of Chinese Pteridophytes; Science Press: Beijing, China, 1990.

300. Chatuvedi, M.; Datta, K.; Nair, P.K.K. Pollen morphology of Oryza (Poaceae). Grana 1998, 37, 79-86. [CrossRef]

301. Zong, Y.; Chen, Z.; Innes, J.B.; Chen, C.; Wang, Z.; Wang, H. Fire and flood management of coastal swamp enabled first rice paddy cultivation in east China. Nature 2007, 449, 459-462. [CrossRef]

302. Zhang, Y.; van Geel, B.; Gosling, W.D.; Sun, G.; Qin, L.; Wu, X. Typha as a wetland food resource: Evidence from the Tianluoshan site, Lower Yangtze Region, China. Veget. Hist. Archaeobot. 2020, 29, 51-60. [CrossRef]

303. Zong, Y.; Innes, J.B.; Wang, Z.; Chen, Z. Environmental change and Neolithic settlement movement in the lower Yangtze wetlands of China. Holocene 2012, 22, 659-673. [CrossRef]

304. Shumilovskikh, L.S.; van Geel, B. Non-pollen palynomorphs. In Handbook for the Analysis of Micro-Particles in Archaeological Sediments; Henry, A.G., Ed.; Springer: Cham, Switzerland, 2020; pp. 65-94.

305. Ingold, C.T. Fungal Spores, Their Liberation and Dispersal; Clarendon Press: Oxford, UK, 1971.

306. van Geel, B. Application of fungal and algal remains and other microfossils in palynological analyses. In Handbook of Palaeoecology and Palynology; Berglund, B.E., Ed.; John Wiley: New York, NY, USA, 1986; pp. 497-505.

307. van Geel, B.; Aptroot, A. Fossil ascomycetes in Quaternary deposits. Nov. Hedwig. 2006, 82, 313-329. [CrossRef]

308. Miola, A. Tools for non-pollen palynomorphs (NPPs) analysis: A list of Quaternary NPP types and reference literature in English language (1972-2011). Rev. Palaeobot. Palynol. 2012, 186, 142-161. [CrossRef]

309. Tapolczai, K.; Anneville, O.; Padisák, J.; Salmaso, N.; Morabito, G.; Zohary, T.; Tadonléké, R.D.; Rimet, F. Occurrence and mass development of Mougeotia spp. (Zygnemataceae) in large, deep lakes. Hydrobiologia 2014. [CrossRef]

310. Birks, H.J.B. Late Wisconsin vegetational and climatic history at Kylen Lake, northeastern Minnesota. Quat. Res. 1981, 16, 322-355. [CrossRef]

311. Atahan, P.; Itzstein-Davey, F.; Taylor, D.; Dodson, J.; Qin, J.; Zheng, H.; Brooks, A. Holocene-aged sedimentary records of environmental changes and early agriculture in the lower Yangtze, China. Quat. Sci. Rev. 2008, 27, 556-570. [CrossRef]

312. Stockmarr, J. Tablets with spores used in absolute pollen analysis. Pollen Spores 1971, 13, 871-873.

313. Itzstein-Davey, F.; Atahan, P.; Dodson, J.; Taylor, D.; Zheng, H. Environmental and cultural changes during the terminal Neolithic: Qingpu, Yangtze delta, eastern China. Holocene 2007, 17, 875-887. [CrossRef]

314. Stanley, D.J.; Chen, Z. Radiocarbon dates in China's Holocene Yangtze delta: Record of sediment storage and reworking, not time of deposition. J. Coast. Res. 2000, 16, 1126-1132.

315. Reimer, P.J.; Bard, E.; Bayliss, A.; Beck, J.W.; Blackwell, P.G.; Bronk Ramsey, C.; Buck, C.E.; Cheng, H.; Edwards, R.L.; Friedrich, M.; et al. IntCal13 and Marine13 radiocarbon age calibration curves 0-50,000 Years cal. BP. Radiocarbon 2013, 55, 1869-1887. [CrossRef]

316. Grimm, E.C. TGView v. 2.0.2, Software; Illinois State Museum, Research and Collections Centre: Springfield, IL, USA, 2004.

317. Long, T.; Qin, J.; Atahan, P.; Mooney, S.; Taylor, D. Rising waters: New geoarchaeological evidence of inundation and early agriculture from former settlement sites on the southern Yangtze Delta, China. Holocene 2014, 24, 546-558. [CrossRef]

318. Li, C.; Wang, P. Late-Quaternary Stratigraphy in Yangtze River Delta, China; Science Press: Beijing, China, 1998.

319. Li, C.; Chen, Q.; Zhang, J.; Yang, S.; Fan, D. Stratigraphy and paleoenvironmental changes in the Yangtze Delta during the Late Quaternary. J. Asian Earth Sci. 2000, 18, 453-469. [CrossRef]

320. Xu, T.; Shi, X.; Wang, G.; Liu, Y.; Liu, S.; Qiao, S.; Yao, Z.; Wang, X.; Fang, X.; Li, X.; et al. Holocene sedimentary evolution and hypoxia development in the subaqueous Yangtze (Changjiang) Delta, China. Mar. Geol. 2020, 430, 106359. [CrossRef]

321. Yang, S. Tidal wetland sedimentation in the Yangtze Delta. J. Coast. Res. 1999, 15, 1091-1099.

322. Liu, K.; Sun, S.; Jiang, X. Environmental change in the Yangtze River delta since 12000 years B.P. Quat. Res. 1992, $38,32-45$. [CrossRef]

323. Wang, Z.; Chen, Z.; Tao, J. Clay mineral analysis of sediments in the Changiang Delta Plain and its application to the Late Quaternary variations of sea level and sediment provenance. J. Coast. Res. 2006, 22, 683-691. [CrossRef]

324. Saint-Laurent, D. Palaeoflood hydrology: An emerging science. Prog. Phys. Geogr 2004, 28, 531-543. [CrossRef]

325. Schillereff, D.N.; Chiverrell, R.C.; Macdonald, N.; Hooke, J.M. Flood stratigraphies in lake sediments: A review. Earth-Sci. Rev. 2014, 135, 17-37. [CrossRef]

326. Zhao, B.; Yan, X.; Wang, Z.; Shi, Y.; Chen, Z.; Xie, J.; Chen, J.; He, Z.; Zhan, Q.; Li, X. Sedimentary evolution of the Yangtze River mouth (East China Sea) over the past 19,000 years, with emphasis on the Holocene variations in coastal currents. Palaeogeogr. Palaeoclimatol. Palaeoecol. 2018, 490, 431-449. [CrossRef] 
327. Stanley, D.J.; Chen, Z.; Song, J. Inundation, sea-level rise and transition from Neolithic to Bronze Age cultures, Yangtze Delta, China. Geoarchaeology 1999, 14, 15-26. [CrossRef]

328. Qin, Y.; Zhao, Y.; Chen, L.; Zhao, S. Geology of the East. China Sea; Science Press: Beijing, China, 1987.

329. Cheng, L.; Ye, W. Multi-proxy evidence for paleoclimate evolution performed on a paleolake sediment core in the East Asian Monsoon Region. Environ. Earth Sci. 2019, 78, 92. [CrossRef]

330. Lin, C.; Huang, Z.; Zhu, S.; Li, C.; Jiang, W. Sedimentary characteristics and processes of Late Quaternary in the Hangzhou Bay coastal plain. Acta Geol. Sin. 1999, 73, 120-130, (In Chinese with English abstract).

331. Tooley, M.J. Sea levels. Prog. Phys. Geogr. 1986, 10, 120-129. [CrossRef]

332. Chen, Z.; Stanley, D.J. Sea-level rise on Eastern China's Yangtze Delta. J. Coast. Res. 1998, 14, 360-366.

333. Dai, B.; Liu, Y.; Sun, Q.; Ma, F.; Chen, J.; Chen, Z. Foraminiferal evidence for Holocene environmental transitions in the Yaojiang Valley, south Hangzhou Bay, eastern China, and its significance for Neolithic occupations. Mar. Geol. 2018, 404, 15-23. [CrossRef]

334. Zhang, Q.; Zhu, C.; Liu, C.; Jiang, T. Environment changes in the Yangtze Delta since 7000 aBP. Acta Geogr. Sin. 2004, 59, 534-542. (In Chinese)

335. Shao, K.; Zhang, J.; He, K.; Wang, C.; Lu, H. Impacts of the wetland environment on demographic development during the Neolithic in the Lower Yangtze region-based on peat and archaeological dates. Front. Earth Sci. 2021, 9, 635-640. [CrossRef]

336. Li, C.; Ming, Q.; Sun, H. Holocene strata and transgression of southern Yangtze delta plain. Bull. Chin. Sci. 1986, $21,1650-1653$.

337. Xiao, J. Pollen results from the Longnan Neolithic settlement. In Environmental Archaeological Research; Zhou, Q., Ed.; Science Press: Beijing, China, 1991; pp. 156-163. (In Chinese)

338. Huang, J.; Lei, S.; Tang, L.; Wang, A.; Wang, Z. Mid-Holocene environmental change and human response at the Neolithic Wuguishan site in the Ningbo coastal lowland of East China. Holocene 2020, 30, 1591-1605. [CrossRef]

339. Yan, D.; Wünnemann, B.; Gao, S.; Zhang, Y. Early Holocene tidal flat evolution in a western embayment of East China Sea, in response to sea level rise episodes. Quat. Sci. Rev. 2020, 250, 106642. [CrossRef]

340. He, K.; Lu, H.; Zheng, Y.; Zhang, J.; Xu, D.; Huan, X.; Wang, J.; Lei, S. Mid-Holocene sea-level fluctuations interrupted the developing Hemudu culture in the lower Yangtze River, China. Quat. Sci. Rev. 2018, 188, 90-103. [CrossRef]

341. Deng, L.; Liu, Y.; He, J.; Jiang, R.; Jiang, F.; Chen, J.; Chen, Z.; Sun, Q. New archaeobotanical evidence reveals synchronous rice domestication 7600 years ago on south Hangzhou Bay coast, eastern China. Anthropocene 2021, 33, 100280. [CrossRef]

342. Zheng, Y.; Zheng, H.; Guo, Q.; Yang, Q.; Hu, Z.; Yao, X.; Zhou, X.; Zhao, K.; Li, X.; Deng, C. Dating the Hemudu Neolithic rice cultivation site, East China, by palaeomagnetic chronostratigraphy. Palaeogeogr. Palaeoclimatol. Palaeoecol. 2021, $569,110297$. [CrossRef]

343. Li, L.; Zhu, C.; Lin, L.; Zhao, Q.; Shi, G.; Zhu, H. Transgression records between 7500-5400 BC on the stratum of the Luotuodun site in Yixing, Jiangsu province. Acta Geogr. Sin. 2008, 63, 1189-1197.

344. Zheng, H.; Zhou, Y.; Yang, Q.; Hu, Z.; Ling, G.; Zhang, J.; Gu, C.; Wang, Y.; Cao, Y.; Huang, X.; et al. Spatial and temporal distribution of Neolithic sites in coastal China: Sea level changes, geomorphic evolution and human adaption. Sci. China Earth Sci. 2018, 61, 123-133. [CrossRef]

345. Zhang, D. Meteorological Record Collection in China over the Last 3,000 Years; Jiangsu Education Press: Nanjing, China, 2013.

346. Yin, S.; Wang, H.; Wang, D.; Huang, C. Study on historical flood disasters and climate change in the upper reaches of the Hanjiang River. Arid Zone Res. 2010, 27, 522-528, (In Chinese with English abstract).

347. Huang, C.; Pang, J.; Zha, X.; Zhou, Y.; Su, H.; Wan, H.; Ge, B. Sedimentary records of extraordinary floods at the ending of the mid-Holocene climatic optimum along the Upper Weihe river, China. Holocene 2012, 22, 675-686. [CrossRef]

348. Li, X.; Huang, C.; Pang, J.; Zhou, Y. Palaeoflood hydrological study in the Baihe Reach in the upper reaches of the Hanjiang River. Sci. Geogr. Sin. 2012, 32, 971-978, (In Chinese with English abstract).

349. Liu, T.; Huang, C.; Pang, J.; Zha, X.; Zhou, Y.; Zhang, Y.; Liu, K. Hydrological reconstructions of the pre-historical great floods in the Wufeng Reach of Yunxian County in the upper Hanjiang River. Acta Geogr. Sin. 2013, 68, 1568-1577, (In Chinese with English abstract).

350. Zha, X.; Huang, C.; Pang, J.; Li, Y. Sedimentary and hydrological studies of the Holocene palaeofloods in the middle reaches of the Jinghe River. J. Geogr. Sci. 2012, 22, 470-478. [CrossRef]

351. Zhang, J.; Chen, F.; Holmes, J.A.; Li, H.; Guo, X.; Wang, J.; Li, S.; Lu, Y.; Zhao, Y.; Qiang, M. Holocene monsoon climate documented by oxygen and carbon isotopes from lake sediments and peat bogs in China: A review and synthesis. Quat. Sci. Rev. 2011, 30, 1973-1987. [CrossRef]

352. Li, D.; Yao, P.; Bianchi, T.S.; Zhao, B.; Pan, H.; Zhang, T.; Wang, J.; Xu, B.; Yu, Z. Historical reconstruction of organic carbon inputs to the East China Sea inner shelf: Implications for anthropogenic activities and regional climate variability. Holocene 2015, 25, 1869-1881. [CrossRef]

353. Zhu, Z.; Feinberg, J.M.; Xie, S.; Bourne, M.D.; Huang, C.; Hu, C.; Cheng, H. Holocene ENSO-related cyclic storms recorded by magnetic minerals in speleothems of central China. Proc. Natl. Acad. Sci. USA 2017, 114, 852-857. [CrossRef]

354. Liu, H.; Gu, Y.; Huang, X.; Yu, Z.; Xie, S.; Cheng, S. A 13,000-year peatland palaeohydrological response to the ENSO-related Asian monsoon precipitation changes in the middle Yangtze Valley. Quat. Sci. Rev. 2019, 212, 80-91. [CrossRef]

355. Liu, Z.; Wen, X.; Brady, E.C.; Otto-Bliesner, B.; Yu, G.; Lu, H.; Cheng, H.; Wang, Y.J.; Zheng, W.; Ding, Y.; et al. Chinese cave records and the East Asia Summer Monsoon. Quat. Sci. Rev. 2014, 83, 115-128. [CrossRef] 
356. Donges, J.; Donner, R.; Marwan, N.; Breitenbach, S.F.; Rehfeld, K.; Kurths, J. Non-linear regime shifts in Holocene Asian monsoon variability: Potential impacts on cultural change and migratory patterns. Clim. Past 2015, 11, 709-741. [CrossRef]

357. Shu, J.; Wang, W.; Chen, W. Holocene vegetation and environment changes in the NW Taihu plain, Jiangsu Province, east China. Acta Micropaleontol. Sin. 2007, 24, 210-221.

358. Xie, S.; Evershed, R.P.; Huang, X.; Zhu, Z.; Pancost, R.D.; Meyers, P.A.; Gong, L.; Hu, C.; Huang, J.; Zhang, S.; et al. Concordant monsoon-driven postglacial hydrological changes in peat and stalagmite records and their impacts on prehistoric cultures in central China. Geology 2013, 41, 827-830. [CrossRef]

359. Zuo, X.; Lu, H.; Li, Z.; Song, B.; Xu, D.; Zou, Y.; Wang, C.; Huan, X.; He, K. Phytolith and diatom evidence for rice exploitation and environmental changes during the early mid-Holocene in the Yangtze Delta. Quat. Res. 2016, 86, 304-315. [CrossRef]

360. Qin, B.; Yu, G. Implications of lake level variations at $6 \mathrm{ka}$ and $18 \mathrm{ka}$ in mainland Asia. Glob. Planet. Chang. 1998, 18, 59-72. [CrossRef]

361. Mao, L.; Mo, D.; Jiang, L.; Jia, Y.; Liu, X.; Li, M.; Zhou, K.; Shi, C. Environmental change since mid-Pleistocene recorded in Shangshan archaeological site of Zhejiang. J. Geogr. Sci. 2008, 18, 247-256. [CrossRef]

362. Zhu, C.; Song, J.; You, K.; Han, H. Research on the reasons of culture interruption in Maqiao Site. Chin. Sci. Bull. 1996, 41, 148-152. (In Chinese)

363. Zhang, Q.; Liu, C.; Zhu, C.; Jiang, T. Environmental change and its impacts on human settlement in the Changjiang river delta in Neolithic age. Chin. Geogr. Sci. 2004, 14, 239-244. [CrossRef]

364. Shi, W.; Ma, C.M.; Zhu, C.; Wang, F.B.; Li, S.J. Analysis of stratigraphy on multiprofiles in the Taihu Lake region and palaeoenvironmental events in the Liangzhu culture epoch. Geogr. Res. 2008, 27, 1129-1138. (In Chinese)

365. Stanley, D.J.; Chen, Z. Neolithic settlement distributions as a function of sea level controlled topography in the Yangtze Delta, China. Geology 1996, 24, 1083-1086. [CrossRef]

366. Zhang, G.; Zhu, C.; Wang, J.; Zhu, G.; Ma, C.; Zheng, C.; Zhao, L.; Li, Z.; Li, L.; Jin, A. Environmental archaeology on Longshan culture (4500-4000 a BP) at Yuhuicun site in Bengbu, Anhui Province. J. Geogr. Sci. 2010, 20, 455-468. [CrossRef]

367. Liu, Y.; Ma, C.; Fan, D.; Sun, Q.; Chen, J.; Li, M.; Chen, Z. The Holocene environmental evolution of the Inner Hangzhou Bay and its significance. J. Ocean. Univ. China 2018, 17, 1301-1308. [CrossRef]

368. Huang, R.; Zhu, C.; Guan, Y.; Zheng, C. Impact of Holocene environmental change on temporal-spatial distribution of Neolithic sites in Huaihe River Basin, Anhui Province. J. Geogr. Sci. 2006, 16, 199-208. [CrossRef]

369. Yasuda, Y.; Fujiki, T.; Nasu, H.; Kato, M.; Morita, Y.; Mori, Y.; Kanehara, M.; Toyama, S.; Yano, A.; Okuno, M.; et al. Environmental archaeology at the Chengtoushan site, Hunan Province, China, and implications for environmental change and the rise and fall of the Yangtze River civilization. Quat. Int. 2004, 123-125, 149-158. [CrossRef]

370. Wang, S.; Huang, J.; Wen, X.; Zhu, J. Evidence and modeling study of droughts in China during 4-2 ka BP. Chin. Sci. Bull. 2008, 53, 2215-2221. [CrossRef]

371. Wu, W.; Zheng, H.; Hou, M.; Ge, Q. The $5.5 \mathrm{cal}$ ka BP climate event, population growth, circumscription and the emergence of the earliest complex societies in China. Sci. China Earth Sci. 2018, 61, 134-148. [CrossRef]

372. Wu, L.; Sun, X.; Sun, W.; Zhu, C.; Zhu, T.; Lu, S.; Zhou, H.; Guo, Q.; Guan, H.; Xie, W.; et al. Evolution of Neolithic site distribution (9.0-4.0 ka BP) in Anhui, East China. J. Geogr. Sci. 2020, 30, 1451-1456. [CrossRef]

373. He, Y.; Theakstone, W.H.; Zhang, Z.; Zhang, D.; Yao, T.; Chen, T.; Shen, Y.; Pang, H. Asynchronous Holocene climatic change across China. Quat. Res. 2004, 61, 52-63. [CrossRef]

374. Tan, L.; An, Z.; Cai, Y.; Long, H. Hydrological representation of the 4.2 ka BP event in China and its global linkages. Geol. Rev. 2008, 54, 94-104. (In Chinese)

375. Bai, J.; Zhou, H.; Zhu, C. Archaeological discovery and research on the remains of the palaeoflood of the Yuxi site. Chin. Sci. Bull. 2008, 53 (Suppl. 1), 18-27.

376. Zhao, C.; Mo, D. Holocene hydro-environmental evolution and its impacts on human occupation in Jianghan-Dongting Basin, middle reaches of the Yangtze River, China. J. Geogr. Sci. 2020, 30, 423-438. [CrossRef]

377. Okuda, M.; Sato, Y.; Tang, L.; Takahashi, M.; Toyama, S.; Yano, A.; Kitagawa, H.; Yasuda, Y. Late Holocene vegetation and environment at Cauduntou, west of Yangtze Delta, SW Jiangsu Province, East China. Quat. Int. 2003, 105, 39-47. [CrossRef]

378. Guo, F.; Hu, Q.; Jiang, T. Annual and seasonal streamflow responses to climate and land-cover changes in the Poyang Lake basin, China. J. Hydrol. 2008, 355, 106-122. [CrossRef]

379. Ma, T.; Rolett, B.V.; Zheng, Z.; Zong, Y. Holocene coastal evolution preceded the expansion of paddy field rice farming. Proc. Natl. Acad. Sci. USA 2020, 117, 24138-24143. [CrossRef] [PubMed]

380. Yi, S.; Saito, Y.; Zhao, Q.; Wang, P. Vegetation and climate changes in the Changjiang Yangtze River Delta, China, during the past 13,000 years inferred from pollen records. Quat. Sci. Rev. 2003, 22, 1501-1519. [CrossRef]

381. Song, J. Changes in dryness/wetness in China during the last 529 years. Int. J. Climatol. 2000, 20, 1003-1015. [CrossRef]

382. Gemmer, M.; Jiang, T.; Su, B.; Kundzewicz, Z.W. Seasonal precipitation changes in the wet season and their influence on flood/drought hazards in the Yangtze river basin, China. Quat. Int. 2008, 186, 12-21. [CrossRef]

383. Su, B.; Gemmer, M.; Jiang, T. Spatial and temporal variation of extreme precipitation over the Yangtze River Basin. Quat. Int. 2008, 186, 22-31. [CrossRef]

384. Chen, W.; Wang, W.; Dai, X. Holocene vegetation history with implication of human impact in the lake Chaohu area, Anhui Province, East China. Veget. Hist. Archaeobot. 2009, 18, 137-146. [CrossRef] 
385. Jiang, T.; Zhang, Q.; Blender, R.; Fraedrich, K. Yangtze Delta floods and droughts of the last millennium: Abrupt changes and long term memory. Theoret. App. Climatol. 2005, 82, 131-141. [CrossRef]

386. Min, Q.; Wang, Z. On the regularity of flood occurrences in Poyang Lake in the past 600 years. J. Lake Sci. 1994, 6, $375-383$.

387. Zhang, X.; Cai, S.; Sun, S. Evolution of Dongting Lake since Holocene. J. Lake Sci. 1994, 6, 13-21. (In Chinese)

388. Du, Y.; Cai, S.; Zhang, X.; Zhao, Y. Interpretation of the environmental change of Dongting Lake, middle reach of Yangtze River, China, by ${ }^{210} \mathrm{~Pb}$ measurement and satellite image analysis. Geomorphology 2001, 41, 171-181. [CrossRef]

389. Dai, S.; Yang, S.; Zhu, J.; Gao, A.; Li, P. The role of Lake Dongting in regulating the sediment budget of the Yangtze River. Hydrol. Earth Syst. Sci. 2005, 9, 692-698. [CrossRef]

390. Shankman, C.; Keim, B.D.; Song, J. Flood frequency in China's Poyang Lake region: Trends and teleconnections. Int. J. Climatol. 2006, 26, 1255-1266. [CrossRef]

391. Liu, T.; Chen, Z.; Sun, Q.; Finlayson, B. Migration of Neolithic settlements in the Dongting Lake area of the middle Yangtze River basin, China: Lake-level and monsoon climate responses. Holocene 2012, 22, 649-657. [CrossRef]

392. Xu, J.; Jian, Y.; Ma, C.; Zhu, C.; Wu, L.; Li, Y.; Wang, X. Geographic distribution of archaeological sites and their response to climate and environmental changes between 10.0-2.8 ka BP in the Poyang Lake Basin, China. J. Geogr. Sci. 2016, 26, 603-618. [CrossRef]

393. Xie, Y.; Li, C.; Wang, Q.; Yin, H. Sedimentary records of paleoflood events during the last 3000 years in Jianghan Plain. Sci. Geogr. Sin. 2007, 27, 81-84. (In Chinese)

394. Shi, C.; Mo, D.; Liu, H.; Mao, L.J. Late Neolithic culture evolution and environmental changes in northern Jianghan Plain east of Hanjiang River. Quat. Sci. 2010, 30, 335-343, (In Chinese with English abstract).

395. Wu, L.; Zhu, C.; Li, F.; Ma, C.; Li, L.; Meng, H.; Liu, H.; Wang, X.; Tan, Y.; Song, Y. Prehistoric flood events recorded at the Zhongqiao Neolithic site in the Jianghan Plain, Central China. Acta Geogr. Sin. 2015, 70, 1149-1164. (In Chinese)

396. $\mathrm{Wu}, \mathrm{X}$.; $\mathrm{Wu}, \mathrm{J}$. The Neolithic sites distribution and its relationship with paleo-environmental changes around Dongting lake area, China. Southeast. Cult. 1998, 1, 35-40. (In Chinese)

397. Mo, D.; Zhao, Z.; Xu, J.; Li, M. Holocene environmental changes and the evolution of the Neolithic cultures in China. In Landscapes and Societies; Martini, I.P., Chesworth, W., Eds.; Springer: Dordrecht, The Netherlands, 2010; pp. $299-319$.

398. Yasuda, Y. Climate change and the origin and development of rice cultivation in the Yangtze River basin, China. Ambio 2008, 37, 502-506. [CrossRef]

399. Zeng, M.; Ma, C.; Zhu, C.; Song, Y.; Zhu, T.; He, K.; Chen, J.; Huang, M.; Jia, T.; Guo, T. Influence of climate change on the evolution of ancient culture from 4500 to 3700 cal. yr BP in the Chengdu Plain, upper reaches of the Yangtze River, China. Catena 2016, 147, 742-754. [CrossRef]

400. Zhu, C.; Xu, J.; Huang, M.; Yang, Z.; Zhang, N.; Jiang, Z.; Bai, T.; Lu, F. Archaeological discoveries and research on the remains of an ancient flood event at the Majie site in the Chengdu Plain. Front. Earth Sci. 2021, 28, 181-201.

401. He, L.; Chen, J.; Yang, L.E.; Li, G.; Lu, C. Social resilience to climate and water-related disasters in the Poyang Lake area (East China) over the past 2000 years. Environ. Res. Lett. 2021, 16, 045007. [CrossRef]

402. Li, X.; Zhang, Q. Variation of floods characteristics and their responses to climate and human activities in Poyang lake, China. Chin. Geogr. Sci. 2015, 25, 13-25. [CrossRef]

403. Zhang, Y.; Zhu, C. Environmental archaeology of the Dachang region in the Daning valley, the Three Gorges reservoir region of the Yangtze River, China. Chin. Sci. Bull. 2008, 53, 140-152. [CrossRef]

404. Xia, Z.; Yang, X.; Ye, M. Prehistoric disasters at Lajia site, Qinghai, China. Chin. Sci. Bull. 2003, 48, $1877-1881$.

405. Ge, Z.; Yang, D.; Li, X.; Ren, Z. The paleoflooding record along the upreaches of the Yangtze River since the late pleistocene epoch. Quat. Sci. 2004, 24, 556-560, (In Chinese with English abstract).

406. Jin, Z.; Yu, J.; Chen, H.; Wu, Y.; Wang, S.; Chen, S. The influence and chronological uncertainties of the 8.2 ka cooling event on continental climate records in China. Holocene 2007, 17, 1041-1050. [CrossRef]

407. Zhu, C.; Shi, W.; Song, Y. Environmental archaeological study on paleoflood since 7 ka BP in the Changiang River delta. In Research on Mountains Disasters and Environmental Protection across Taiwan Strait (Series1); Cui, P., Ed.; Sichuan Sciences \& Technology Press: Chengdu, China, 1998; pp. 85-90. (In Chinese)

408. Zhu, C.; Wu, L.; Li, L.; Zheng, C.; Li, Z.; Ma, C.; Tan, Y.; Zhao, Q.; Wang, K.; Lin, L.; et al. Research progress on Holocene environmental archaeology in the Yangtze River Valley, China. Acta Geogr. Sin. 2014, 69, 1268-1283. (In Chinese)

409. Zhu, C.; Zheng, C.; Wu, L. Environmental Archaeology since the Neolithic Age in the Yangtze River Valley, China; Science Press: Beijing, China, 2015. (In Chinese)

410. Wu, L.; Lu, S.; Zhu, C.; Ma, C.; Sun, X.; Li, X.; Li, C.; Guo, Q. Holocene environmental archaeology of the Yangtze River Valley in China, a review. Land 2021, 10, 302. [CrossRef]

411. Jiang, L. (Ed.) Kuahuqiao; Wenwu Press: Beijing, China, 2004. (In Chinese)

412. Zheng, Y.; Sun, G.; Qin, L.; Li, C.; Wu, X.; Chen, X. Rice fields and modes of rice cultivation between 5000 and 2500 BC in east China. J. Arch. Sci. 2009, 36, 2609-2616.

413. Sun, G. Recent research on the Hemudu culture and the Tianluoshan site. In A Companion to Chinese Archaeology; Underhill, A.P., Ed.; Wiley-Blackwell: West Sussex, UK, 2013; pp. 555-573.

414. Yuan, J.; Flad, R.; Luo, Y. Meat-acquisition patterns in the Neolithic Yangzi river valley, China. Antiquity 2008, 82, 351-366. 
415. Fuller, D.Q.; Qin, L. Declining oaks, increasing artistry, and cultivating rice: The environmental and social context of the emergence of farming in the Lower Yangtze Region. Environ. Archaeol. 2010, 15, 139-159. [CrossRef]

416. Qiu, Z.; Shang, X.; Ferguson, D.K.; Jiang, H. Archaeobotanical analysis of diverse plant food resources and palaeovegetation at the Zhumucun site, a late Neolithic settlement of the Liangzhu culture in East China. Quat. Int. 2016, 426, 75-85. [CrossRef]

417. Yao, L.; Yang, Y.; Sun, Y.; Cui, Q.; Zhang, J.; Wang, H. Early Neolithic human exploitation and processing of plant foods in the Lower Yangtze River, China. Quat. Int. 2016, 426, 56-64. [CrossRef]

418. Zhang, Y. Exploring the wetland: Integrating the fish and plant remains into a case study from Tianluoshan, a Middle Neolithic site in China. In Environmental Archaeology: Interdisciplinary Contribution to Archaeology; Pişkin, E., Marciniak, A., Bartkowiak, M., Eds.; Springer International Publishing AG: Cham, Switzerland, 2018; pp. 199-227.

419. Zhang, Y. Causes of Liangzhu culture's disappearance from micropaleontology. Sci. Geogr. Sin. 2007, $27,376-379$.

420. Yu, S.; Zhu, C.; Qu, W. Mid-Holocene climatic transition and rapid interruption in Neolithic cultures in the eastern plain of Taihu Lake. Sci. Geogr. Sin. 1999, 19, 549-554, (In Chinese with English abstract).

421. Zhang, L.; Wu, J.; Liu, S. Relationship between human activities and environmental changes in the Yangtze Delta of China before Qin Dynasty. Acta Geogr. Sin. 2000, 55, 661-670, (In Chinese with English abstract).

422. Deng, H.; Chen, Y.; Jia, J.; Mo, D.; Zhou, K. Distribution patterns of the ancient cultural sites in the middle reaches of the Yangtze River since 8500 a BP. Acta Geogr. Sin. 2009, 64, 1113-1125. (In Chinese)

423. Chen, L. Progress in environmental evolvement and environmental archaeology study in the Yangtze Delta (China). Geo-Spatial Inf. Sci. 2008, 11, 228-234. [CrossRef]

424. Zhang, Y.; Zhu, C.; Shi, W. Middle and late Holocene climatic changes and sea level changes and paleo-floods of Maqiao, Shanghai. Mar. Sci. 2002, 26, 54-58, (In Chinese with English abstract).

425. Wiener, M. The interaction of climate change and agency in the collapse of civilisations ca. 2200-2000 BC. Radiocarbon 2014, 56, S1-S16. [CrossRef]

426. Zhang, X.; Huang, D.; Deng, H.; Snape, C.; Meredith, W.; Zhao, Y.; Du, Y.; Chen, X.; Sun, Y. Radiocarbon dating of charcoal from the Bianjiashan site in Hangzhou: New evidence for the lower age limit of the Liangzhu culture. Quat. Geochron. 2015, 30, 9-17. [CrossRef]

427. Guo, Y.; Mo, D.; Mao, L.; Jin, Y.; Guo, W.; Mudie, P.J. Settlement distribution and its relationship with environmental changes from the Paleolithic to Shang-Zhou period in Liyang Plain, China. Quat. Int. 2014, 321, 29-36. [CrossRef]

428. Wang, X.; Mo, D.; Li, C.; Yu, S.; Xue, B.; Liu, B.; Wang, H.; Shi, C. Environmental changes and human activities at a fortified site of the Liangzhu culture in eastern China: Evidence from pollen and charcoal records. Quat. Int. 2017, 438, 189-197. [CrossRef]

429. Zhang, J.; Xia, Z. Deposition evidences of the 4 ka BP flood events in Central China plains. Acta Geogr. Sin. 2011, 66, 685-697, (In Chinese with English abstract).

430. Shi, B.; Huang, C.; Pang, J.; Zha, X. Palaeoflood events and climate change at the turning time from the Shang to Zhou Dynasty in the Longmen reach of the Yellow River. J. Lake Sci. 2017, 29, 234-245, (In Chinese with English abstract).

431. Xiao, J.; Zhang, S.; Fan, J.; Wen, R.; Xu, Q.; Inouchi, Y.; Nakamura, T. The 4.2 event and its resulting cultural interruption in the Daihai Lake basin at the East Asian summer monsoon margin. Quat. Int. 2019, 527, 87-93. [CrossRef]

432. Fan, S.; Zhang, T.; Chen, S.; Hu, J.; Lu, Y.; Du, H. Debris flow events of 4000 a BP and its resulting archaeological site destruction in Qian River gorge, the upper reach of Wei River, central China. Geol. J. 2020, 55, 7371-7384. [CrossRef]

433. Chen, Z.; Stanley, D.J. Quaternary subsidence and river channel migration in the Yangtze Delta plain, eastern China. J. Coast. Res. 1995, 11, 927-945.

434. Schneiderman, J.S.; Chen, Z.Y.; Eckert, J.O. Heavy minerals and river channel migration in the Yangtze delta plain, eastern China. J. Coast. Res. 2003, 19, 326-335.

435. Chen, Z.; Zong, Y.; Wang, Z.; Wang, H.; Chen, J. Migration patterns of Neolithic settlements on the abandoned Yellow and Yangtze River deltas of China. Quat. Res. 2008, 70, 301-314. [CrossRef]

436. Shen, H.; Zhu, C.; Jia, Y. Impact of geomorphology and environmental variance on Neolithic culture evolution in Taihu Basin. Sci. Geogr. Sin. 2004, 24, 580-585, (In Chinese with English abstract).

437. Zhu, G.; Zhu, C.; Ling, S.; Wang, J.; Yang, X. Spatial-temporal distribution of Neolithic and Xia-Shang-Zhou Dynasties sites and relationship between human and environment in Anhui Province. Sci. Geogr. Sin. 2005, 25, 346-352, (In Chinese with English abstract).

438. Shi, C.; Mo, D.; Li, C. The relationship between environmental evolution and human activities in Liangzhu Sites Group, Zhejiang Province. Earth Sci. Front. 2011, 18, 347-356. (In Chinese)

439. Ge, Q. Climate Change through Ancient Chinese Dynasty; Science Press: Beijing, China, 2011.

440. Wei, Z.; Rosen, A.M.; Fang, X.; Su, Y.; Zhang, X. Macro-economic cycles related to climate change in dynastic China. Quat. Res. 2015, 83, 13-23. [CrossRef]

441. Li, M.; Mo, D.; Mao, L.; Sun, G.; Zhou, K. Palaeosalinity in the Tianluoshan site and the correlation between the Hemudu culture and its environmental background. J. Geogr. Sci. 2010, 20, 441-454. [CrossRef]

442. Innes, J.B.; Zong, Y.; Chen, Z.; Chen, C.; Wang, Z.; Wang, H. Environmental history, palaeoecology and human activity at the early Neolithic forager/cultivator site at Kuahuqiao, Hangzhou, eastern China. Quat. Sci. Rev. 2009, 28, 2277-2294. [CrossRef] 